If you do not need this publication ofter it has served your purpose, please return it to the Geological Survey, using the official mailing label at the end

UNITED STATES DEPARTMENT OF THE INTERIOR

FOSSIL PLANTS FROM

THE COLGATE MEMBER OF THE FOX HILLS SANDSTONE AND ADJACENT STRATA

GEOLOGICAL SURVEY PROFESSIONAL PAPER 189-I 
UNITED STATES DEPARTMENT OF THE INTERIOR

Harold L. Ickes, Secretary

GEOLOGICAL SURVEY

W. C. Mendenhall, Director

Professional Paper 189-I

\section{FOSSIL PLANTS FROM THE COLGATE MEMBER OF THE FOX HILLS SANDSTONE AND ADJACENT STRATA}

BY

ROLAND W. BROWN

Shorter contributions to general geology, 1937

(Pages 239-275)

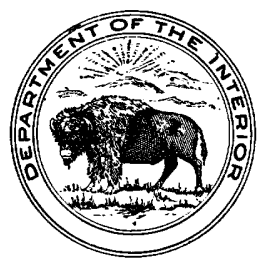

UNITED STATES

GOVERNMENT PRINTING OFFICE

WASHINGTON : 1939

For sale by the Superintendent of Documents, Washington, D. C. - - - - - - - Price 15 cents 


\section{CONTENTS}

Abstract
Introduction.
Colgate member of Fox Hills sandstone plant localities in the Fox Hills sandstone
Summary of the flora of the Fox Hills sandstone
Hell Creek formation
Changes of name.
Systematic descriptions.
Index

\section{ILLUSTRATIONS}

Plate 47. Views of the Colgate member of the Fox Hills sandstone and Hell Creek formation in southeastern Montana and southwestern North Dakota: $A$, Erosion remnant of Colgate sandstone 5 miles southwest of Glendive, Mont.; $B$, Outcrop of white Colgate sandstone overlain by somber-hued Hell Creek strata 4 miles southwest of Glendive, Mont.; $C$, Hell Creek formation north of the station of the Chicago, Milwaukee, St. Paul \& Pacific Railroad at.

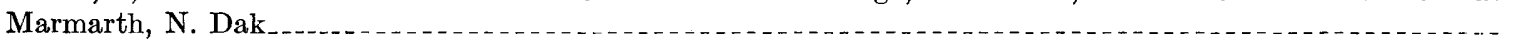

48-63. Fossil plants from the Colgate member of the Fox Hills sandstone and adjacent strata

FigURE 30. Index map showing distribution of the Fox Hills sandstone 


\title{
FOSSIL PLANTS FROM THE COLGATE MEMBER OF THE FOX HILLS SANDSTONE AND ADJACENT STRATA
}

\author{
By Roland W. Brown
}

\section{ABSTRACT}

The Colgate member, uppermost unit of the Fox Hills sandstone, has yielded 19 species of well-preserved fossil plants at the type locality, southwest of Glendive, Mont. Small collections have been obtained from other localities in equivalent or related Fox Hills strata, making a total of 37 species now known from the Fox Hills sandstone. These species indicate that the flora is intermediate between the floras of the Mesaverde and Laramie formations and that it lived in a mesophytic, warm temperate environment.

Significant collections from a number of localities in the overlying Hell Creek formation have yielded, besides other plants, a characteristic species of cycad, Nilssonia gibbsii, hitherto unreported from these strata. It confirms the testimony of the Triceratops dinosaur fauna as to the Upper Cretaceous age of the Hell Creek formation.

\section{INTRODUCTION}

Plant fossils, although relatively scarce, have been reported occasionally from the continental and shore facies of the Fox Hills sandstone. Few of these came to public notice before Knowlton ${ }^{1}$ in 1916 described a small collection, comprising 13 species, from the vicinity of Milliken, Colo. Previous to that publication, A. G. Leonard and M. R. Campbell, in 1906, collected some fragmentary leaves from the lower beds of the Fox Hills sandstone exposed at Iron Bluff, 8 miles southwest of Glendive, Mont. Knowlton identified 6 species in that collection. ${ }^{2}$ Knowlton and A. C. Peale, in 1907, discovered the locality in the Colgate member $1 \frac{1}{2}$ miles southwest of Glendive, Mont., that yielded to them and subsequent collectors, including T. W. Stanton, C. E. Dobbin, J. B. Reeside, Jr., and the writer, a variety of well-preserved specimens. Knowlton did not describe any of these plants. Another small collection was made by M. A. Pishel in 1909 from the Fox Hills sandstone in sec. 7, T. 17 N., R. 24 E., S. Dak. Knowlton tentatively identified 11 species in this collection in an unpublished report to W. R. Calvert.

With all these collections now at hand it is the purpose of this paper to report upon the composition of the flora of the Fox Hills sandstone and to show the relation of that flora to other floras from equivalent or adjacent strata. It is hoped that this information will fill a gap

\footnotetext{
1 Knowlton, F. H., The flora of the Fox Hills sandstone: Geol. Survey Prof. Paper 98-H, pp. 85-93, pls. 15-18, 1916.

2 Calvert, W. R., Geology of certain lignite fields in eastern Montana: Geol. Survey Bull. 471, p. 195, 1912.
}

in our knowledge of plant history during the Upper Cretaceous sequence in the western interior region of the United States.

The collection of plants from the Colgate member was incidental to the study of the Cretaceous-Eocene boundary question that I have been making in recent years. In the course of this work I have also made significant collections from the overlying Hell Creek formation. In order that, pending the complete report, there may be no undue delay in making known some of the pertinent information I have assembled in regard to the Hell Creek flora, I am including in this paper a record of some important localities together with observations on several diagnostic species.

For valuable assistance in connection with the studies here reported I gratefully acknowledge indebtedness to K. J. Murata, F. S. MacNeil, C. E. Dobbin, and J. B. Reeside, Jr., of the Geological Survey; to Erling Dorf, of Princeton University; and to many friends living in the region where the fossils were collected.

All the types of new species herein described are deposited in the United States National Museum.

\section{COLGATE MEMBER OF FOX HILLS SANDSTONE}

The Colgate member of the Fox Hills sandstone was defined by Calvert ${ }^{3}$ and named from its typical exposure for several miles along the base of the bluffs on the south side of the Yellowstone River in the vicinity of Colgate station, southwest of Glendive, Mont. Seen from a distance the Colgate member at this locality is a white band of sandstone, averaging 35 feet in thickness, and in striking contrast with the underlying and overlying somber-colored strata. (See pl. 47, B; also pls. 4 and 5, Geol. Survey Prof. Paper 158-B, and pl. 23, Geol. Soc. America Bull., vol. 35.) It emerges from the general valley level about $1 \frac{1}{2}$ miles southwest of Glendive, then rises gently westward to the crest of the Cedar Creek anticline, 11\%2 miles southwest of Glendive, beyond which it dips steeply and disappears into the west flank of that anticline.

On closer inspection the Colgate member is found to be a massive, locally cross-bedded sandstone, but

${ }^{3}$ Calvert, W. R., Geology of certain lignite fields in eastern Montana: Geol. Survey Bull. 471, pp. 194, 195, 1912. 
usually not well bedded. It is friable, with a rough but fine-grained texture, and weathers into an intricately ornamental channeled surface where steep slopes of it are exposed. (See pl. 47, A.) It consists chiefly of angular quartz and feldspar grains, with a few scattered flakes of mica and other minor constituents, all held together loosely by white interstitial material composed of sericite and clay.

Although this band of white sandstone appears to be a distinct unit, it is in reality not so sharply demarked from the preceding and succeeding strata as the conspicuous difference in color might at first suggest. Neither the base nor the top of the sandstone is separated from the adjacent strata by other than minor local erosional discordances. ${ }^{4}$ At many outcrops the Colgate member is an undivided, fairly homogeneous unit, but at other exposures it has a parting consisting of a thin seam of impure coal, in places 2 feet thick, or several feet of reddish-brown carbonaceous shale containing fossil plants.

At Iron Bluff, ${ }^{5}$ the first high point south of the Northern Pacific Railway tracks after crossing Sand Creek, 8 miles southwest of Glendive, the white color of the Colgate sandstone is obscured by weathering products from the brown and somber-colored overlying strata of the Hell Creek formation. The section at Iron Bluff is as follows:

\section{Section at Iron Bluff, 8 miles southwest of Glendive, Mont.}

Hell Creek formation: Sandstone, brown and platy at top; light gray, rusty, and cross-bedded below _........ 41 Fox Hills sandstone:

Colgate member; white, massive, partly stained sandstone................................ 44

Lower member; brown and yellow sandstone and gray and brown sandy shale..._._._._.

Pierre shale: Dark-colored marine shale with fossiliferous concretions

The most recent map of this area, by Erdmann and Larsen, ${ }^{6}$ is at variance with the foregoing section in that it shows the upper strata at Iron Bluff as consisting entirely of the Fox Hills sandstone. However, as pointed out by Dobbin and Reeside ${ }^{7}$ and as verified by Dobbin, Brown, and MacNeil in 1936, Iron Bluff and its immediate neighboring high points to the south are capped by the basal ferruginous sandstones of the Hell Creek formation.

Outside the type area on the northern half of the Cedar Creek anticline, the Colgate member has been

\footnotetext{
4 Dobbin, C. E., and Reeside, J. B., Jr., The contact of the Fox Hills and Lance formations: Geol. Survey Prof. Paper 158-B, pp. 9-29, 1929.

$\checkmark$ It appears that the rugged ridge formed by the steeply dipping strata of the west flank of the Cedar Creek anticline has also sometimes been called Iron Bluff. Under this locality name Lester Ward, for example, reported Fort Union plants occurring there in the red, clinkered sandstones and shales overlying burned coal beds. (Geol. Survey 6th Ann. Rept., p. 542, 1886.)

${ }^{6}$ Erdmann, C. E., and Larsen, R. M., Geologic and structure contour map of the northern half of the Cedar Creek anticline, Dawson, Prairie, Wibaux, and Fallon Counties, Mont., Geol. Survey, 1934.

${ }^{7}$ Dobbin, C. E., and Reeside, J. B., Jr., op. cit., pp. 16, 17.
}

recognized as a lithologic unit along the southern half of that anticline, ${ }^{8}$ and along the Missouri River in the area between the mouths of Hell Creek and the Musselshell River. White or grayish-white sandstones suspected of being the stratigraphic equivalents of the Colgate member occur near the top of the Fox Hills sandstone in the Standing Rock and Cheyenne Indian Reservations, North and South Dakota; in the region surrounding the Porcupine uplift west of Forsyth, Mont.; and also in the neighborhood of Pompey's Pillar, Mont. Only the locality in sec. 7, T. 17 N., R. 24 E., S. Dak., has yielded identifiable fossil plants, which, while not conclusive as to correlation of that sandstone with the type Colgate, are at least indicative of approximately the same age - namely, late Fox Hills. Eastward from the type locality the Colgate sandstone changes in color from white to grayish brown and in character from a fresh-water to a brackish-water deposit.

The general distribution of the Fox Hills sandstone is shown in figure 30 .

Calvert, as stated above, originally defined the Colgate as a member of the Lance formation. The term was applied to 175 feet, more or less, of arenaceous strata overlying the Cretaceous marine Pierre shale, this unit being based upon a section measured by A. G. Leonard at Iron Bluff and vicinity. ${ }^{9}$ Leonard, however, while standing on Iron Bluff and pondering the surrounding geologic situation, did not suspect that the top of the 35 -foot white sandstone, which is "the most prominent stratum in the region," was 40 feet below him and not above the brown sandstone that "forms the summit of Iron Bluff." As is now known, there are at Iron Bluff about 100 feet of yellowishbrown and gray shales and sandstones between the top of the Pierre shale and the base of the Colgate. It was within this unit, 75 feet above the Pierre shale, that Leonard and Campbell in 1906, as reported by Calvert, made a collection of fragmentary fossil leaves that Knowlton identified as follows:
Sequoia nordenskiöldi Heer.
Populus cuneata Newberry.
Populus amblyrhyncha? Newberry.
Viburnum newberryanum? Ward.
Viburnum sp.? (no margin).
Platanus sp., probably P. haydenii Newberry.

On the basis of these identifications Knowlton pronounced the age to be Tertiary. Calvert, therefore, speculating as to the probability of the Fox Hills sandstone being present in the region at all, states that it may be represented by the 70-foot interval between the top of the Pierre shale and the horizon at which the fossil plants were found.

\footnotetext{
E Dobbin, C. E., and Larsen, R. M., Geologic and structure-contour maps of the southern half of the Cedar Creek anticline, Fallon County, Mont., and Bowman County, N. Dak., Geol. Survey, 1934.

${ }^{9}$ See Dobbin, C. E., and Reeside, J. B., Jr., op. cit., p. 16.
} 
In 1924 Thom and Dobbin ${ }^{10}$ redefined the term "Colgate sandstone" to include only the conspicuous 35 feet, more or less, of white sandstone, the base of which is about 100 feet above the Pierre shale, and to beds immediately underlying the Colgate on Sand Creek, just east of Iron Bluff, contain Fox Hills marine fossils. (2) The somber-colored beds overlying the Colgate contain abundant remains of Triceratops dinosaurs and

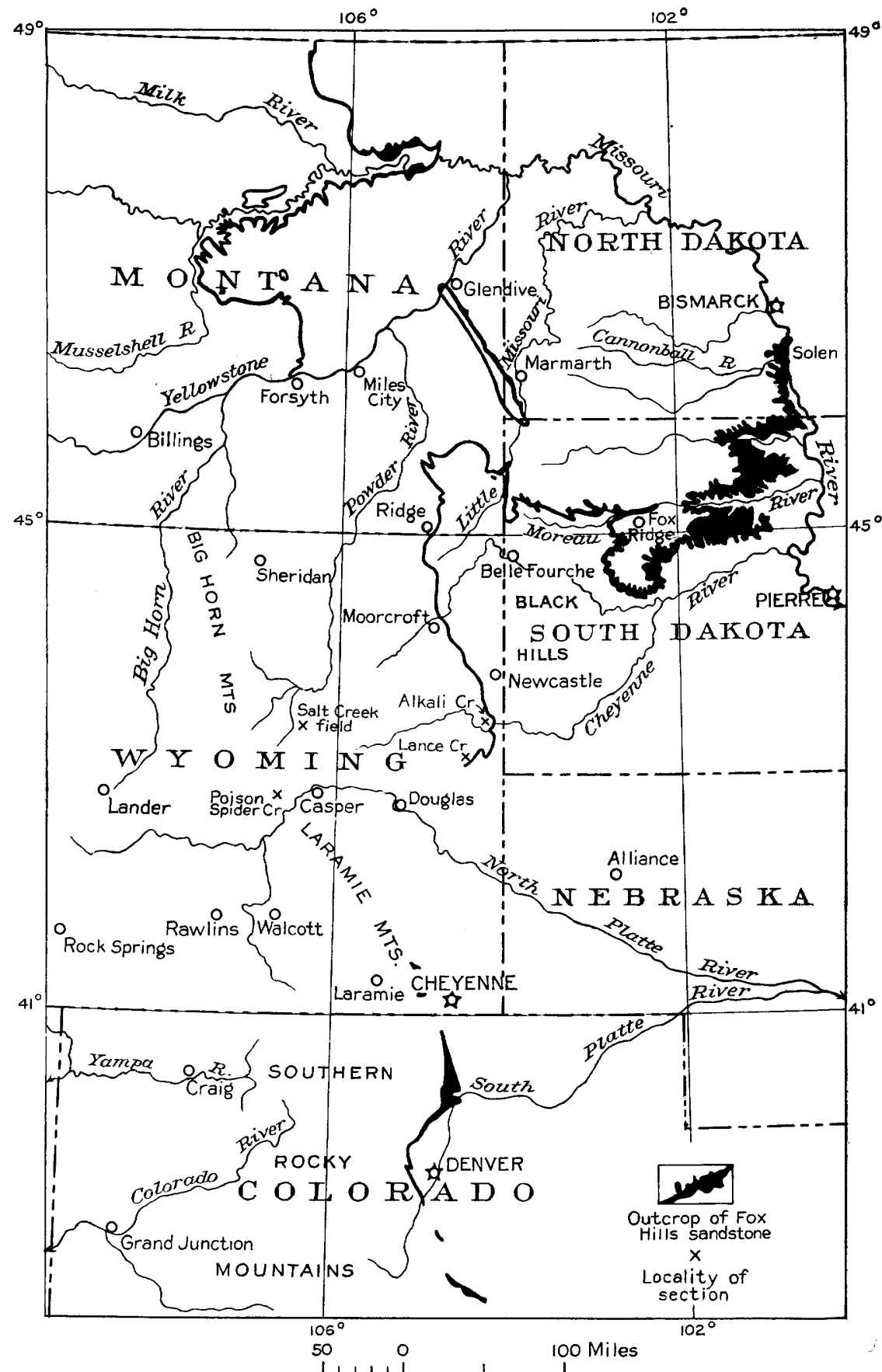

Figure 30.-Index map showing distribution of the Fox Hills sandstone. Reproduced from Geol. Survey Prof. Paper 158-B, p. 12, 1929.

be regarded as the upper member of the Fox Hills sandstone.

That the 145-foot section of arenaceous beds (which includes the Colgate member) overlying the marine Pierre shale at Iron Bluff is not Eocene but Cretaceous in age is demonstrated by at least four facts: (1) The

\footnotetext{
${ }^{10}$ Thom, W. T., Jr., and Dobbin, C. E., Stratigraphy of Cretaceous-Eocene transition beds in eastern Montana and the Dakotas: Geol. Soc. America Bull., vol. 35, p. $490,1924$.
}

a flora that includes characteristic Cretaceous cycads. (3) The Colgate is gradational eastward into the marine facies of the Fox Hills on Little Beaver Creek south of Baker, Mont. (4) The fossil flora is a Cretaceous flora having somewhat the same aspect as that of the Laramie of the Denver Basin.

The latter statement, it will be observed, is at variance with Knowlton's quoted opinion regarding the age of the collection made at 75 feet above the Pierre 
shale at Iron Bluff and other fragmentary collections from horizons not far removed in the same general region. Three of Knowlton's species, however, are questioned, and one is compared but not identified with a Tertiary species. Only two species are unquestioned, but these, Sequoia nordenskiöldi Heer and Populus cuneata Newberry, together with the other fragments in the list, can now be assigned confidently to Upper Cretaceous species.

\section{FOSSIL PLANT LOCALITIES IN THE FOX HILLS SANDSTONE}

Iron Bluff, Mont.: Geological Survey locality 4143. As already noted, A. G. Leonard and M. R. Campbell in 1906 made what is probably the first recorded collection of fossil plants from the Fox Hills sandstone at a horizon 25 feet below the Colgate member at Iron Bluff, 8 miles southwest of Glendive, Mont. These fossils are fragmentary and poorly preserved in a hard, ferruginous, irregularly bedded sandstone. The list has been given above (p. 240) and has there received comment.

Glendive, Mont.: Localities 4269, 4969, 7655, 8194, 8515. (These numbers refer to the same locality in the Colgate but to different times and collectors. No. 4269 will be used in subsequent parts of this paper for this locality.) F. H. Knowlton and A. C. Peale made the next collection from the Colgate member itself. Knowlton's notebook for July 18, 1907, reads:

Today visited the bluffs at the north end of Eagle Bluff, about 2 miles southwest of the town of Glendive, and at the point near the first cut on the Northern Pacific Railroad and just west of the dry creek crossing the railroad. The basal member exposed here is a white coarse-grained friable sandstone above which is a bed of yellowish sandstone with numerous irregular lenses and concretions. At this place the white sandstone is almost 10 feet thick, and from the upper 5 or 6 feet obtained a good collection of beautifully preserved leaves, representing the following genera: Platanus, Quercus, Laurus, Rhamnus, and probably Salix. This flora is unlike any seen thus far and may be Laramie.

This quotation is interesting as a record that Knowlton's first impression, reversed in 1909, pointed toward the Cretaceous, not Eocene age of the flora.

Collections from this same locality were made by T. W. Stanton, July 1, 1908; C. E. Dobbin and J. B. Reeside, Jr., in 1923; R. W. Brown and K. J. Murata in 1931; and C. E. Dobbin, R. W. Brown, and F. S. MacNeil in 1936.

Locality 8564. R. W. Brown and F. S. MacNeil, also in 1936, made a small collection from a carbonaceous lens within the Colgate member on the east side of Sand Creek in sec. 27, T. 15 N., R. 55 E., 61/2 miles southwest of Glendive.

These two localities, $1 \frac{1}{2}$ miles and $6 \frac{1}{2}$ miles respectively southwest of Glendive, are the only fossiliferous localities reported in the Colgate member in the type region. Southeastward toward Marmarth the problematic fossil Halymenites major Lesquereux, supposed by Lesquereux to be a seaweed, appears in the shore phase of the Colgate.
Because the Colgate sandstone is unevenly bedded the fossil leaves are likely to occur at any angle in the matrix. To get good specimens it is necessary to remove large blocks of the sandstone, preferably a foot or more on a side, and then split as indicated by the black streaks on the broken faces that suggest the presence of leaves and other plant remains. The black leaves against their white background possess unusual attractiveness, and one who finds entire specimens feels rewarded for the hard labor required to excavate them.

The species recorded in this paper from the Colgate member are as follows:

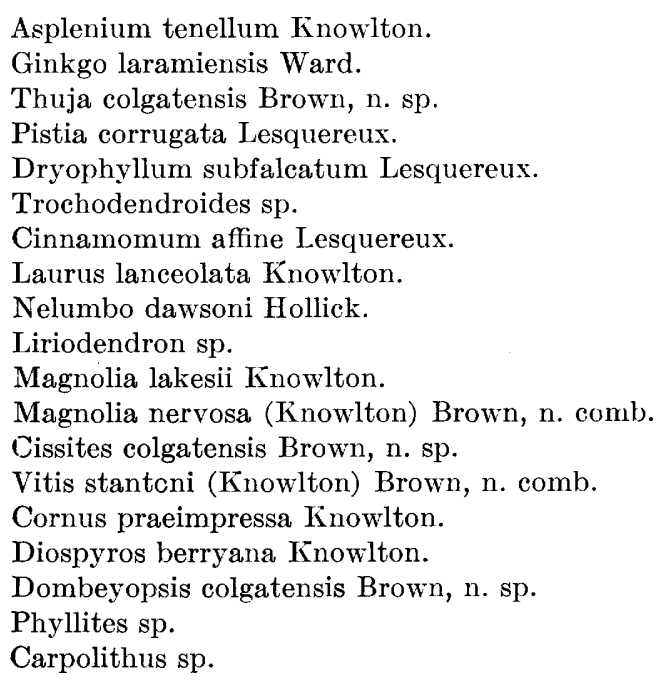

Milliken, Colo.: Localities 6810, 6920, 6921. The collections from the vicinity of Milliken were made by T. E. Williard and T. W. Stanton in 1914 and 1915 and came from a yellowish-brown, rather coarse sandstone about 100 feet below the top of the formation. Previously this horizon had been prospected by J. J. Stevenson in 1873 and 1878 , by Junius Henderson in1906, and by W. T. Lee in 1910. Their collections, however, did not come to prominent, formal notice until Knowlton integrated them and described the following 13 species in 1916:

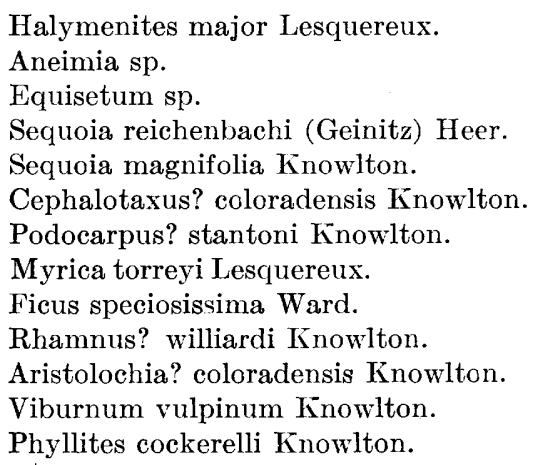

All but four of these species were said to be new, but the flora was regarded as intermediate between the older floras of the Montana group and the overlying Laramie. One species, Viburnum vulpinum, is synonymized in the present paper with Vitis stantoni. A few other species in the list need further study before they can be placed satisfactorily. Only Vitis stantoni and Halymenites major are also found in the Colgate member. The 
general aspect of this flora suggests a somewhat different and probably older ecologic facies than that found in the Colgate.

South Dakota: Locality 5436. The type locality of the Fox Hills sandstone is near Fox Ridge, between the Cheyenne and Moreau Rivers, S. Dak., but the sandstone there carries only abundant marine fossils. Few localities have yielded plant fossils other than the problematic seaweed, Halymenites major. The principal plant-fossil locality so far reported is in the Standing Rock and Cheyenne Indian Reservation, in the northeast corner of sec. 7, T. 17 N., R. 24 E. A collection made there by $\mathrm{M}$. A. Pishel in 1909 from a hard gray sandstone contains the following six species:

Nilssonia gibbsii (Newberry) Hollick.

Pistia corrugata Lesquereux.

Dryophyllum subfalcatum Lesquereux.

Paranymphaea hastata Brown, n. sp.

Platanus sp.

Phyllites sp.

The first three species in the list occur in the type Colgate at Glendive, Mont., but the flora is obviously too small to permit a statement claiming correlation of the two sandstones.

\section{SUMMARY OF THE FLORA OF THE FOX HILLS SANDSTONE}

From the localities in the Fox Hills sandstone listed above there are, including those forms not specifically named, 37 species now known. The accompanying table of distribution shows the outside occurrence, if any, of the Fox Hills species so far as these have been published and have been recognized in other formations. Although they have genera in common, the Fox Hills flora and the Upper Cretaceous floras of the eastern United States have few identical species.

Of the Fox Hills flora, apparently only six species survive in the overlying Hell Creek formationNilssonia gibbsii, Ginkgo laramiensis, Sequoia reichenbachi, Dryophyllum subfalcatum, Magnolia nervosa, and Titis stantoni. The following characteristic and readily identifiable species seem to have vanished from this region near the end of Fox Hills time: Pistia corrugata, Nelumbo dawsoni, Paranymphaea hastata, and Cissites colgatensis.

According to the distribution table the flora of the Fox Hills sandstone shows a marked relationship to those of the Mesaverde, Vermejo, Laramie, and Hell Creek. If our knowledge of the latter floras were on a sounder basis it would most likely be possible to state definitely to which of these floras the Fox Hills flora is most closely related, but much remains to be done with these floras before specific and satisfactory comparisons can be made. In general, however, the Fox Hills flora appears to be intermediate between the floras of the Mesaverde and Laramie formations.

Distribution of recognizable species from the Fox Hills sandstone and Hell Creek formation

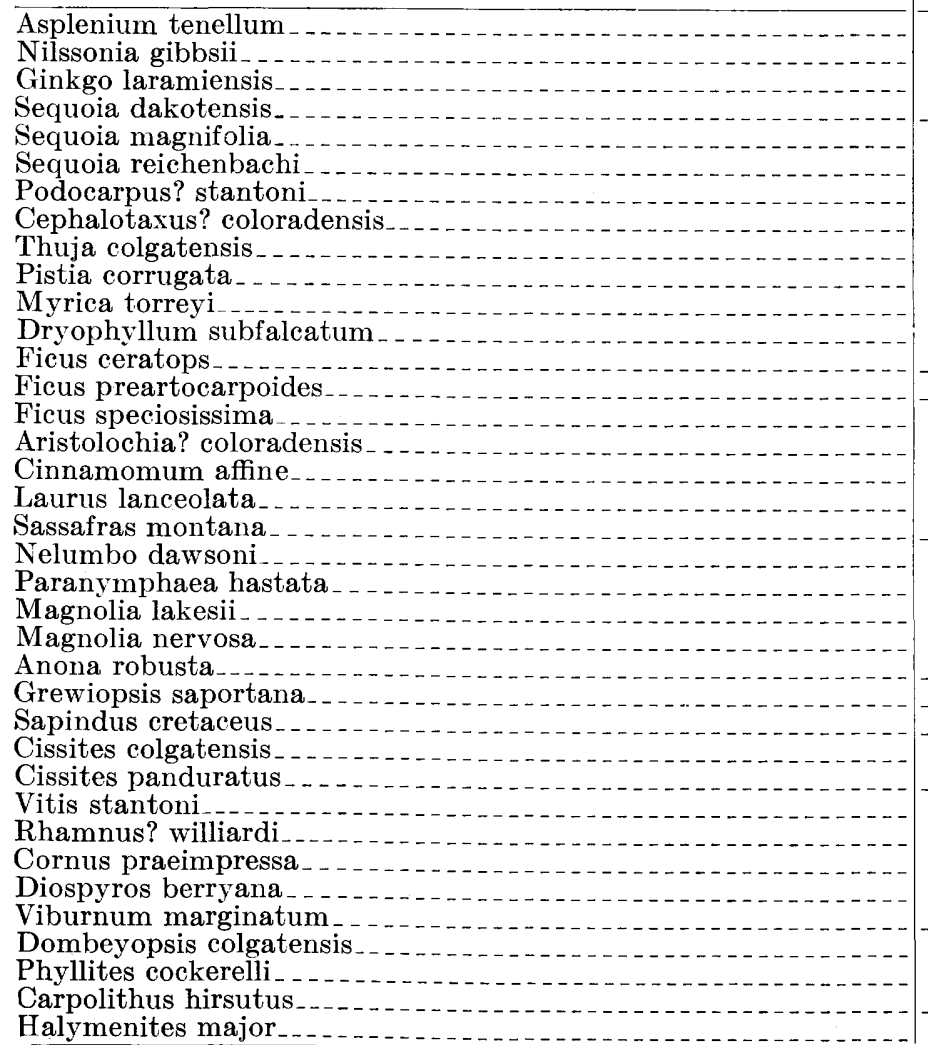

\begin{tabular}{|c|c|c|c|c|c|c|c|c|c|c|c|c|}
\hline 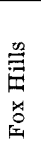 & 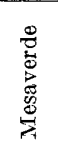 & 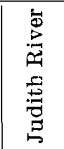 & 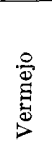 & 莺 & 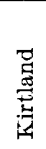 & 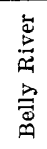 & 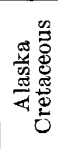 & 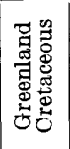 & 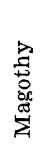 & 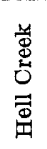 & 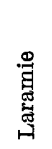 & 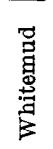 \\
\hline & $x$ & & & & & & & 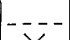 & & & & \\
\hline & $x$ & & & & & & $\begin{array}{l}x \\
x\end{array}$ & $\stackrel{x}{x}$ & -1 & & & \\
\hline & & & & & & & & & & & & \\
\hline & & $x$ & $x$ & $x$ & - & - & $x$ & $x$ & & $x$ & & \\
\hline & & & & & & & & & & & & \\
\hline & & $\bar{X}$ & & & $X$ & & & & & & & \\
\hline & $\hat{y}$ & & $x$ & $x$ & $\hat{-}$ & & & & & & & \\
\hline & $x$ & & & & & & & & & & & \\
\hline & & & & -1 & -1 & & & & & $x$ & & \\
\hline & $x$ & $\ldots$ & $x$ & $\cdots$ & $\cdots$ & -- & & & & & & \\
\hline & $x$ & & & & & & & & & & $x$ & \\
\hline & & & & & & & & & & & & \\
\hline & & & & & & $x$ & & & & & & $\bar{x}$ \\
\hline & & & & & & & & & & & $x$ &.-- \\
\hline & & & $x$ & $\cdots$ & & & & & & $X$ & -- & $\cdots$ \\
\hline & & & & --1 & & & & & & $\stackrel{x}{x}$ & $x$ & $\ldots$ \\
\hline & & & & & & & & & & & & \\
\hline & & & $x$ & & & & & & & $x$ & & \\
\hline & & $\times$ & & & & & & & & $x$ & & \\
\hline & & & & & & & & & & & $\underset{x}{x}$ & \\
\hline & $x$ & & & & & & & & - & $\bar{x}$ & & $\ldots$ \\
\hline & & & & & & & & & & & & \\
\hline & & & & & & & & & $x$ & $x$ & & \\
\hline
\end{tabular}


It is impossible, in my judgment, because of our limited knowledge, to do more than guess as to the climatic implications of the Fox Hills flora. That the flora lived in a fairly moist or mesophytic environment is obvious from the fact that maidenhair trees (Ginkgo), sequoias, water lettuce (Pistia), broad-leaved oaks (Dryophyllum), figs, water lilies (Nelumbo, Paranymphaea), magnolias, grapes (Cissites, Vitis), dogwoods, and persimmons were associated. Unless these ancient species had environmental requirements different from those of their modern relatives, the climate must have been at least warm temperate.

\section{HELL CREEK FORMATION}

The strata immediately overlying the Fox Hills sandstone are somber-hued sandstones and carbonaceous shales with a few thin coal seams. The name Hell Creek formation, ${ }^{10 a}$ from typical exposures on Hell Creek, a small tributary of the Missouri River, 20 miles north of Jordan, Mont., is applied to these beds. They are noted for carrying rather abundant Triceratops bones and only rarely the teeth, jaws, or skulls of primitive mammals. Fossil plants are also abundant but for the most part are not well preserved. Occasionally, however, a shale lens contains excellent plant remains.

The new or significant species described here are chiefly those collected during my investigation of the Cretaceous-Eocene boundary problem in the Rocky Mountain and Plains region. Although a complete discussion of the flora from the Hell Creek formation is not yet practicable, it nevertheless seems opportune to publish such important information as I have assembled.

The localities yielding fossils from this formation are as follows:

Southwest of Glendive, Mont.: Locality 8197. The brown sandstone overlying the Colgate member $1 \frac{1}{2}$ miles southwest of Glendive and in the mesas just south of the railroad trestle over the dry wash at that point yielded some of the best material.

Locality 4004 . The label accompanying the specimens collected from locality 4004 reads: "Bluffs of Yellowstone, $1 \frac{1 / 2}{2}$ miles from Glendive, Mont. Beds lying about 400 feet above the Pierre shale and 200 feet above the river. Collected by Campbell, Leonard, and Holgate, August 6, 1906." The horizon is evidently high in the blufts between localities 8197 and 8531 , overlooking the site at the base of the bluffs where most of the plants from the Colgate member were collected.

Locality 8531. About 1 mile west of locality 8197, in the steep bluffs and 125 feet above the level of the railroad tracks, the carbonaceous sandy shales are packed with fragmentary ferns and dicotyledonous leaves, but the best-preserved fossil is the fruit Carpolithus hirsutus.

\footnotetext{
10a Brown, Barnum, The Hell Creek beds of the Upper Cretaceous of Montana: Am. Mus. Nat. Hist. Bull., vol. 23, pp. 823-845, 1907.
}

Locality 4144 . This locality is 8 miles southwest of Glendive, embracing the vicinity of Iron Bluff and the heights surrounding the basin of Sand Creek, from the upper strata of which came some of the earlier "somberbed" collections made by Leonard and studied by Knowlton.

East of Glendive, Mont.: Locality 8518. About 3 miles east of Glendive along the old road to Wibaux gray sandstones 100 feet below the top of the Hell Creek formation carry principally Viburnum marginatum in abundance and beautifully preserved.

Northwest of Circle, Mont.: Locality 8514. About 40 miles northwest of Circle, Mont., the Big Dry Creek and its tributaries have cut badlands in the terrane of their drainage basin, thus exposing steep bluffs of Hell Creek and overlying strata. In the slopes overlooking Bug Creek and about 75 feet above the level of Big Dry Creek is the bed that yields the fossil fruits called Ficus ceratops. It is a hard gray sandstone, weathering buft, and has a rough external surface caused by the differential erosion of small soft clay boulders, impressions of carbonized twigs and branches, casts of "figs," and deformed leaves included in the matrix. Triceratops and turtle remains are abundant in the adjacent strata.

Locality 8260 . This locality is about 1 mile south of locality 8514, and the horizon is 30 feet above the level of Big Dry Creek.

I am particularly indebted to George Fountain, proprietor of the Gladstone Hotel, Circle, Mont., for his valuable assistance as guide and collector in the region including localities 8260 and 8514, northwest of Circle.

Marmarth, N. Dak.: Localities 8242, 8555. To the north of the Chicago, Milwaukee, St. Paul \& Pacific Railway station at Marmarth is a low bluff (pl. 47,C) of Hell Creek strata, in which, near the top, a conspicuous channel sandstone and shale is exposed. These beds yielded a large variety of well-preserved leaves and fruits.

Cannonball River, N. Dak.: Localities 6600, 8219. The somber-colored beds of the Hell Creek formation may be seen in the drainage basins of Cedar Creek and the Cannonball River west of the Missouri River in south-central North Dakota, and again along the Little Missouri River in the region about Marmarth in the southwestern part of the State. ${ }^{11}$ Localities 6600 and 8219 in these beds are the same-namely, 1 mile southwest of the Wade farm, in sec. 36 , T. 131 N., R. 86 W. Here cones of Sequoia dakotensis and fragments of dicotyledonous leaves weather out of a ferruginous layer.

Locality 8221 . This locality is 30 miles south of Mandan, in the badlands a short distance east on the highway toward Solen, in sec. 32 , T. 134 N., R. 86 W.

\footnotetext{
11 See Stanton, T. W., The fauna of the Cannonball marine member of the Lance: Geol. Survey Prof. Paper 128-A, fig. 1, 1921.
} 


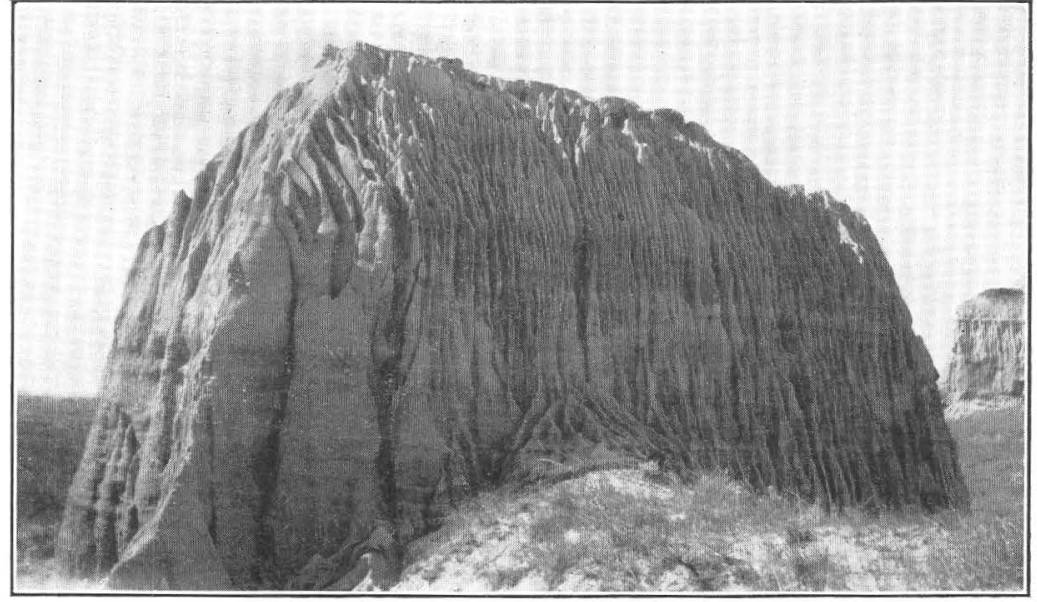

A. EROSION REMNANT OF COLGATE SANDSTONE 5 MILES SOUTHWEST OF GLENDIVE, MONT.

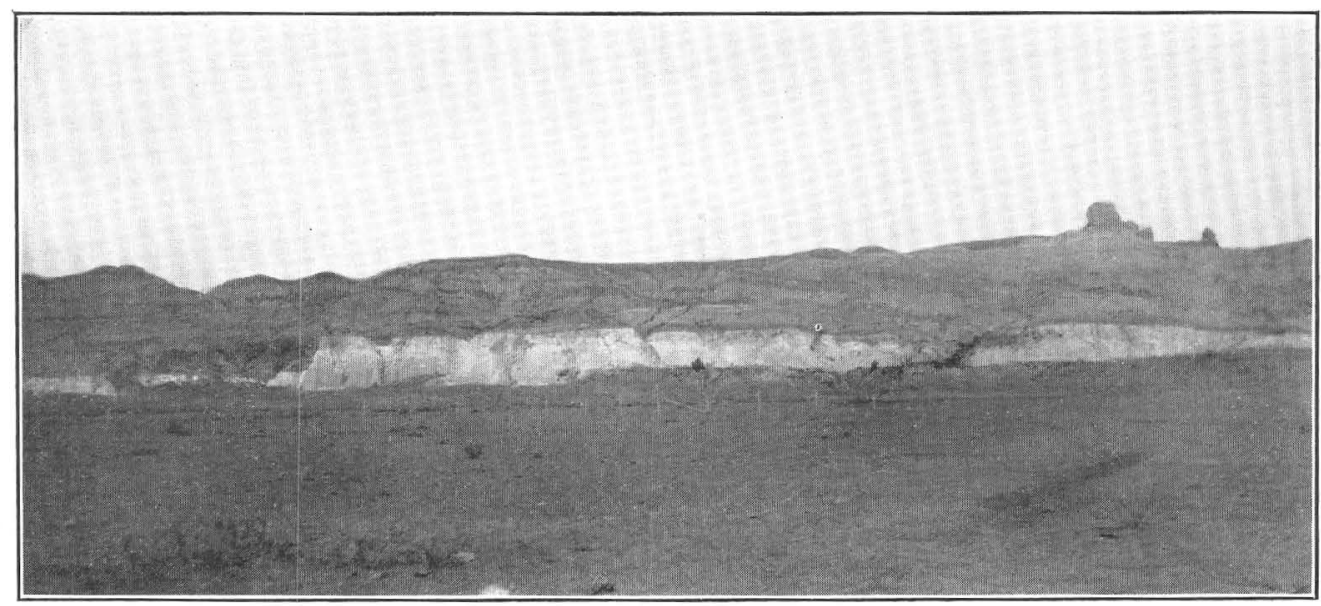

B. OUTCROP OF WHITE COLGATE SANDSTONE OVERLAIN BY SOMBER-HUED HELL CREEK STRATA 4 MILES SOUTHWEST OF GLENDIVE, MONT,

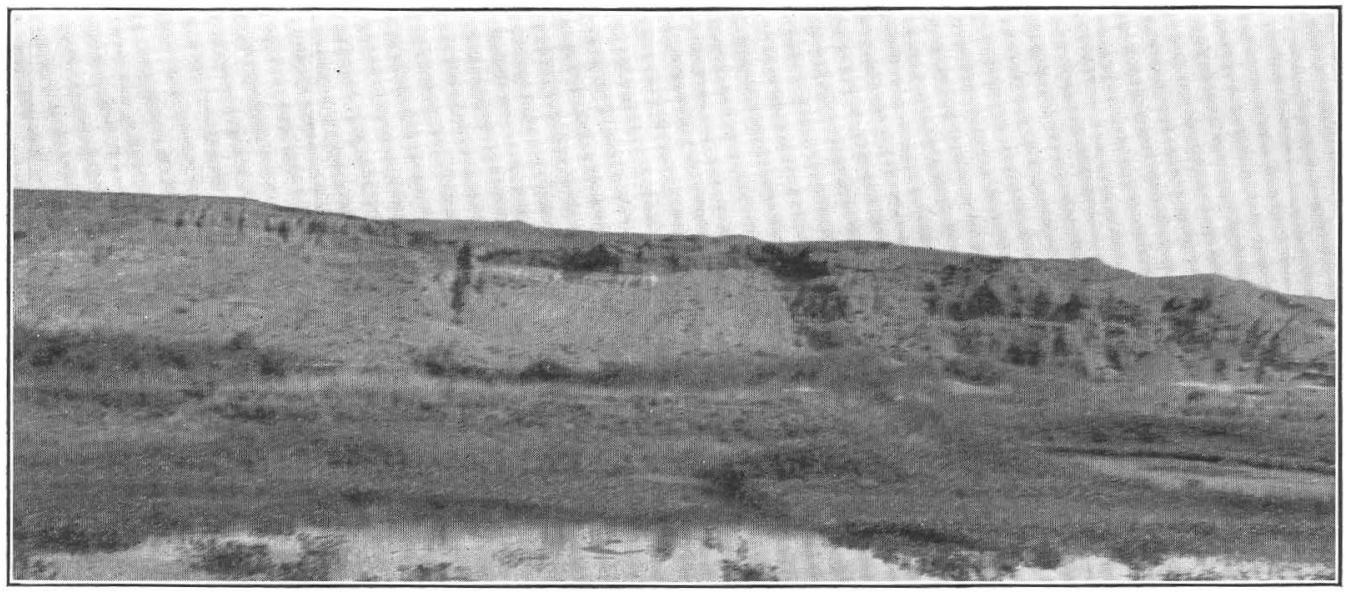

C. HELL CREEK FORMATION NORTH OF THE STATION OF THE CHICAGO, MILW AUKEE, ST. PAUL \& PACIFIC RAILROAD AT MARMARTH, N. DAK.

VIEWS OF THE COLGATE MEMBER OF THE FOX HILLS SANDSTONE AND HELL CREEK' FORMATION IN SOUTHEASTERN MONTANA AND SOUTHWESTERN NORTH DAKOTA. 
A ferruginous stratum, similar to that at locality 6600 , here also yields cones of Sequoia dakotensis and fragments of other plants.

Glenrock, Wyo.: Locality 8551. About 6 $\frac{1}{2}$ miles north of Glenrock, Wyo., the highway going north crosses a bridge over Sand Creek. Half a mile east of the bridge and on the north bank of the creek is a coal mine (operated by Roy Mullinix, Parkerton, Wyo., September 5, 1936). The carbonaceous shale above the coal carries abundant though frą̧mentary fossil plants, of which the most interesting stratigraphically are the portions of fronds and seeds of a cycad, probably an advanced form of the Cretaceous Podozamites latipennis. As these strata occur ahove those carrying the latest Triceratops fauna, it is likely that they are later than the highest Hell Creek beds and are of early Tertiary age. At present they are designated Lance (Tertiary?).

The species from the localities in the Hell Creek formation described or referred to here are as follows:

Nilssonia gibbsii (Newberry) Hollick.

Ginkgo laramiensis Ward.

Sequoia dakotensis Brown.

Dryophyllum subfalcatum Lesquereux.

Trochodendroides sp.

Ficus ceratops Knowlton.

Ficus preartocarpoides Brown, n. sp.

Sassafras montana Brown, n. sp.

Magnolia nervosa (Knowlton) Brown, n. comb.

Anona robusta Lesquereux.

Grewiopsis saportana Lesquereux.

Sapindus eretaceus Brown, n. sp.

Cissites panduratus Knowlton.

Vitis stantoni (Knowlton) Brown, r. comb.

Viburnum marginatum Lesquereux.

Phyllites sp.

Carpolithus hirsutus Newberry.

Coniferous seed.

Carpolithus sp.

So far as the species of this list are characterized in the systematic portion of this paper, and so far as the records show, few survived as such into Fort Union time. (See distribution table, p. 243.) It is of particular interest to report the characteristic Upper Cretaceous cycad, Nilssonia gibbsii, the presence of which in the Hell Creek formation should remove any remaining doubts as to the age of those beds.

\section{CHANGES OF NAME}

Castalia stantoni Knowlton=Vitis stantoni (Knowlton) Brown, n. comb.

Dryophyllum aquamarum Ward=Dryophyllum subfalcatum Lesquereux.

Dryophyllum bruneri Ward=Dryophyllum subfalcatum Lesquereux.

Dryophyllum falcatum Ward=Dryophyllum subfalcatum Lesquereux.

Fraxinus leei Berry=Dryophyllum subfalcatum Lesquereux.

Ginkgo adiantoides (Unger) Heer [part]=Ginkgo laramiensis Ward.
Ginkgo crenulata Hollick $=$ Ginkgo laramiensis Ward.

Ginkgo dawsoni Knowlton= Ginkgo laramiensis Ward.

Ginkgo minor Hollick= Ginkgo laramiensis Ward.

Ginkgo pseudadiantoides Hollick= Ginkgo laramiensis Ward.

Ginkgo pseudadiantoides major Hollick=Ginkgo laramiensis Ward.

Ginkgo reniformis Hollick [not Heer]=Ginkgo laramiensis Ward. Ginkgo sp. Hollick = Ginkgo laramiensis Ward.

Nilssonia lata Dawson = Nilssonia gibbsii (Newberry) Hollick.

Nilssonia yukonensis Hollick = Nilssonia gibbsii (Newberry) Hollick.

Ottelia americana Lesquereux $=$ Pistia corrugata Lesquereux.

Pterospermites nervosum Knowlton=Magnolia nervosa (Knowlton) Brown, n. comb.

Quercus turbulenta Hollick=Dryophyllum subfalcatum Lesquereux.

Quercus whitmani Knowlton=Dryophyllum subfalcatum Lesquereux.

Thuja cretacea? (Heer) Newberry $=$ Thuja colgatensis Brown, $\mathrm{n}$. name.

Vitis dakotana Berry=Vitis stantoni (Knowlton) Brown, $\mathrm{n}$. comb.

Vitis vulpinum Knowlton $=$ Vitis stantoni $($ Knowlton $)$ Brown, $\mathrm{n}$. comb.

\section{SYSTEMATIC DESCRIPTIONS}

PTERIDOPHYTA
POLYPODIACEAE

\section{Asplenium tenellum Knowlton}

Plate 48, figure 1

Asplenium tenellum Knowlton, Geol. Survey Bull. 163, p. 19, pl. 3, figs. 1, 2, 1900.

The fragment figured here represents a slender, delicate fern and is apparently the same as Knowlton's. species.

Occurrence: Colgate member, locality 8564, Glendive, Mont.

\section{SPERMATOPHYTA \\ CYCADACEAE}

\section{Nilssonia gibbsii (Newberry) Hollick}

Plate 49, figures 5, 6; plate 52, figure $6 \mathrm{~b}$

Taeniopteris gibbsii Newberry, Boston Jour. Nat. History, vol. 7, p. $512,1863$.

Nilssonia johnstrupi Heer, Flora fossilis arctica, vol. 6, pt. 2, p. 44, pl. 6, figs. 1-6. 1882.

Nilssonia lata Dawson, Royal Soe. Canada Trans., vol. 1, sec. 4, p. 24, pl. 4, figs. 15 bis, 15a, 1882 [1883].

Nilssonia yukonensis Hollick, Geol. Survey Prof. Paper 159, p. 42, pl. 3, figs. 1-7a; pl. 7, fig. 4, 1930.

Hollick distinguished Nilssonia yukonensis from $N$. gibbsii chiefly by the fact that his specimens had what he thought was an apical sinus. A reexamination of the specimens having this supposed sinus shows that the sinus is merely the result of damage to the tip of the leaf. It appears, therefore, that all the forms here synonymized probably represent a single Upper Cretaceous species.

The specimen shown in plate 49 , figure 5 , has had an interesting history. It was included with fragmentary material collected, according to the label, by Campbell, 
Leonard, and Holgate August 6, 1906, along the bluffs of the Yellowstone River 11/2 miles southwest of Glendive, Mont., from beds lying 400 feet above the Pierre shale and 200 feet above the river. In 1909 Knowlton ${ }^{12}$ published the identifications of species in this collection as follows:

Onoclea sensibilis fossilis Newberry.

Sequoia nordenskiöldi Heer.

Ginkgo adiantoides (Unger) Heer.

In 1935 I checked this collection, finding three species labeled in Knowlton's handwriting, but failing to find a single specimen of Onoclea sensibilis fossilis or any other fern. The Sequoia and Ginkgo specimens with their labels are unmistakable. I conclude, therefore, that Knowlton made a hasty identification, erroneously calling the Nilssonia specimen Onoclea sensibilis fossilis, which is a well-recognized Fort Union species but unreported from earlier strata; hence Knowlton's predilection for assigning an Eocene age to this collection.

Had Knowlton recognized this specimen for what it is-namely, an Upper Cretaceous cycad-would he have insisted that it, like some of the Triceratops dinosaurs, was a relic from the Cretaceous in Eocene strata, or would he have modified his position to admit that the Hell Creek formation with the last of the Triceratops dinosaurs and older types of cycad represented the last lithologic chapter of the Upper Cretaceous story of the Western Interior?

Occurrence: Fox Hills sandstone, locality 5436, S. Dak. (pl. 49, fig. 6 ; pl. 52, fig. 6b). Hell Creek formation, locality 4004, Glendive, Mont. (pl. 49, fig. 5).

\section{Podozamites latipennis Heer \\ Plate 49, figures 1-4}

Podozamites latipennis Heer, Flora fossilis aretica, vol. 6, pt. 2, p. 42 , pl. 14, figs. 1-9; pl. 15, figs. 2a, 3b, 1882 .

Berry, Canada Nat. Mus. Bull. 58, p. 59, 1929.

This species differs from the generalized Jurassic and Lower Cretaceous form, Podozamites lanceolatus (Lindley and Hutton) C. F. W. Braun, in having longer and broader pinnae and veins that bifurcate or anastomose more frequently at a greater distance from the point of attachment of the pinna. In the specimens of $P$. lanceolatus that I have examined in which I could see the venation clearly the veins are more closely spaced, and most veins fork only once, and that within a short distance of the point of attachment of the pinna.

The fragments of Podozamites latipennis are very abundant in the carbonaceous shale at locality 8551 and are associated with species of Sequoia or Taxodium, Oreodaphne or Cinnamomum, Celastrinites, Trochodendroides, and Ficus. Scattered through the matted leaf remains in the shale are numerous irregularly rounded, compressed, and striated bodies (figs. 3,4 ) partly em-

\footnotetext{
12 Knowlton, F. H., The stratigraphic relations and paleontology of the "Hell Creek beds", "Ceratops be $1 s "$ and equivalents, and their reference to the Fort Union formation: Washington Acad. Sci. Proc., vol. 11, p. 198, 1939.
}

bedded in the carbonized remains of what appear to have been shells or rinds. These, I am convinced, are the more or less crushed fruits of P. latipennis, for they are of the size and appearance that one would postulate in the light of comparable living cycad fruits. They are, so far as I know, the first fossil cycad fruits of the more advanced types to be reported from strata in North America proper. Heer ${ }^{13}$ has figured somewhat larger fruits as those of Nilssonia johnstrupi from Upernivik, Greenland.

Heer's types of Podozamites latipennis were collected on the peninsula of Atanekerdluk, west Greenland. They were associated with ferns, horsetails, sequoias, Williamsonia cretacea, and fragmentary dicotyledonous leaves-a Cretaceous flora. Berry's material came from the upper part of the Blairmore formation, Alberta, Canada.

The strata yielding the fossils reported here are depicted on the 1925 geologic map of Wyoming as near the top of the Lance formation (Tertiary?). These strata lie above the highest reported occurrences of Triceratops remains and at a level that, after a long barren interval, marks the resumption of lignite deposition-criteria that at approximately the same horizon in Montana indicate, in my opinion, the transition from the Mesozoic to the Cenozoic. It is possible that I have misidentified this cycad, or it may be an advanced form of the Cretaceous Podozamites latipennis that crossed the Mesozoic-Cenozoic boundary.

Occurrence: Lance formation, locality 8551, Glenrock, Wyo.

\section{GINKGOACEAE}

\section{Ginkgo laramiensis Ward}

Plate 48, figures 12-18; plate 59, figures 1-3

Ginkgo laramiensis Ward, Science [2d ser.], vol. 5, p. 496, fig. 7 , 1885; Geol. Survey 6th Ann. Rept., p. 549, pl. 31, fig. 4, 1886; Geol. Survey Bull. 37, p. 15, pl. 1, fig. 4, 1887.

Knowlton, Geol. Survey Bull. 163, p. 31, pl. 4, figs. 7-10; pl. 5, fig. 5, 1900.

Hollick, Geol. Survey Prof. Paper 159, p. 49, pl. 12, figs. 3, 4, 1930 .

Ginkgo dawsoni Knowlton, Geol. Survey Bull. 696, p. 302, 1919 [formerly G. pusilla Dawson].

Ginkgo reniformis Hollick [not Heer], Geol. Survey Prof. Paper 159 , p. 49 , pl. 12 , figs. $5-7,1930$.

Ginkgo crenulata Hollick, idem, p. 49, pl. 12, figs. 1, 2.

Ginkgo pseudadiantoides Hollick, idem, p. 49, pl. 3, fig. 7b; pl. 13, figs. $8-12$; pl. 28 , fig. 4 a.

Ginkgo pseudadiantoides major Hollick, idem, p. 50, pl. 13, fig. 13. Ginkgo minor Hollick, idem, p. 50, pl. 2, fig. 4b; pl. 13, figs. 1-7; pl. 19 , figs. $6 \mathrm{~b}, 7 \mathrm{~b} ; \mathrm{pl} .29$, figs. $2 \mathrm{c}, 4 \mathrm{c}, 6 \mathrm{a}$.

Ginkgo sp.? Hollick, idem, p. 49, pl. 11, fig. 9.

Ginkgo adiantoides (Unger) Heer. [Parts of the following citations:]

Knowlton, Washington Acad. Sci. Proc., vol. 11, pp. 197, 198, 1909.

Berry, Canada Geol. Survey Mem. 182, p. 17, 1935.

Shaparenko, Philippine Jour. Sci., vol. 57, no. 1, p. 12, 1925. (See included bibliography, pp. 22-25.)

${ }_{13}$ Heer, Oswald, Flora fossilis arctica, vol. 6, pt. 2, p. 44, pl. 6, figs. 4c, 6, 1882. 
Shaparenko, after stating the difficulties attending the separation of fossil species of Ginkgo from one another and these, especially the post-Jurassic species, from the only living species, $G$. biloba Linnaeus, synonymizes nearly all the post-Jurassic species with $G$. adiantoides (Unger) Heer. His synonymy includes G. laramiensis Ward and several other species reported from Cretaceous strata. He stresses the point, observed by many other students, that all the leaves of Ginkgo found in strata younger than Jurassic can be matched by leaves from the living species; but he is also careful to state that the leaves of young trees are most likely to resemble the ancient fossil species in form and lobing. Older trees when damaged or heavily pruned may put forth vigorous young shoots low on the trunk, and these may also produce the ancient types of foliage. In other words, the living species may occasionally exemplify the generalization that "ontogeny repeats phylogeny."

The effect of Shaparenko's proposal to unite all the post-Jurassic species with Ginkgo adiantoides is to deny that fossil remains from the long line of Ginkgo can be of much assistance to the stratigrapher. Is a more helpful view possible? I think there is, and the basis for it lies in determining the characters of the average mature type of leaf in abundant material from the same geologic horizon and from a number of localities. Thus, in the abundant material from the Jurassic of Douglas County, Oreg., the average type of mature leaf is the much and deeply lobed cuneate form, $G$. digitata. During Upper Cretaceous time the average form was still cuneate, but the tendency was to be entire, undulate, or only slightly bilobate, as in G. laramiensis. From the Eocene onward the average type was reniform and bilobate and is typified by G. adiantoides. However, as one swallow does not make a summer, so one fossil Ginkgo leaf does not always provide certain identification of the species - a disadvantage in this method, because abundant material from any one locality is usually the exception rather than the rule. I conclude, therefore, that, although many species of Ginkgo may have existed, at least three form species, G. digitata, G. laramiensis, and G. adiantoides, can be distinguished and may be used as indices of large Mesozoic and Cenozoic time intervals. The application of this method obviously requires the exercise of discrimination, a quality that cannot be communicated by keys or printed descriptions.

I should add that the type specimen of Ginkgo laramiensis is, besides being fragmentary, not typical. As examples of typical material I may cite several specimens figured here (pl. 48, figs. 14, 17; pl. 59, figs. 2, 3), also $G$. minor Hollick (his pl. 13, figs. 3, 6) and $G$. pseudadiantoides Hollick (his pl. 13, fig. 11; pl. 28, fig. 4a). One specimen of Knowlton's G. laramiensis (his pl. 4 , fig. 8) is a reversion toward the Jurassic G. digi- tata, and several specimens of Hollick's G. minor (his pl. 13, figs. 1, 4) are prophetic of the living $G$. biloba. Florin ${ }^{13 a}$ has separated some species of fossil Ginkgo by noting differences in epidermal structures. A readable account of the fossil and living ginkgos by Seward ${ }^{13 b}$ was published recently.

Occurrence: Colgate member, locality 4269, Glendive, Mont. (pl. 48, figs. 13-18). Hell Creek formation, locality 8197, Glendive, Mont. (pl. 48, fig. 12); locality 4144 (pl. 59, figs. 1-3).

\section{TAXODIACEAE}

\section{Sequoia dakotensis Brown}

Plate 48, figures 6-10

Sequoia dakotensis Brown, Washington Acad. Sci. Jour., vol. 25, p. 447, figs. 1-4, 1935.

These Upper Cretaceous cones were distinguished from others on the basis of their having an average of 30 scales. It has not been determined what foliage belongs with this species, although numerous Upper Cretaceous species have been identified on the basis of twigs and foliage. It will be the good fortune some day of someone to find foliage and cones on the same branch.

Occurrence: Hell Creek formation, locality 6600, Cannonball River, N. Dak. (figs. 6-8); locality 8242, Marmarth, N. Dak. (fig. 10); locality 8260, Circle, Mont. (fig. 9).

\section{CUPRESSACEAE}

Thuja colgatensis Brown, n. name

Plate 48, figures 2-4

Thuja cretacea? (Heer) Newberry. Knowlton, Geol. Survey Bull. 257, p. 133, pl. 16, figs. 3, 3a, 1905.

As Knowlton pointed out, this species is apparently distinguished from Thuja interrupta Newberry, which is very common in the Fort Union formation, by its more slender form, an effect created by the long, smooth internodes between the points where the upper expanded portion of the leaves becomes decurrent on the branch. It does not seem to me that this species is identical with $T$. cretacea, from the Magothy formation of the Atlantic Coastal Plain. It seems to be related to several species described by Heer from the Cretaceous of Alaska and Greenland, but without the type specimens for comparison it is almost hopeless to attempt correlation.

Figure 2 illustrates a transverse portion of a cone, showing three faintly striated scales. If this cone-no other coniferous remains were found at this localitybelongs with the foliage it casts some doubt on the identification of the foliage as Thuja, for the cone has characters that suggest Chamaecyparis instead.

Occurrence: Colgate member, locality 8564, Glendive, Mont.

13a Florin, Rudolf, Die fossilen Ginkgophyten von Franz Joseph Land: Paleontographica, Band 82, A bt. B, pp. 1-72, 1936.

13b Seward, A. C., The story of the maidenhair tree: Sci. Progress, vol. 32, pp $420-440,1938$. 


\section{ARACEAE}

\section{Pistia corrugata Lesquereux}

Plate 49 , figures $7-9$; plate 56 , figure 6 a

Pistia corrugata Lesquereux, U. S. Geol. Survey T'err. Rept., vol. 7, p. 103, pl. 61, figs. 1, 3, 4, 6, 7, 9-11, 1878.

Knowlton, Geol. Survey Bull. 163, p. 31, 1900; Geol. Survey Prof. Paper 98-S, p. 334, pl. 85, fig. 4, 1916

Ottelia americana Lesquereux, U. S. Geol. Survey Terr. Rept., vol. 7 , p. 98 , pl. 61 , fig. 8 .

Knowlton, Geol. Survey Bull. 163, p. 32, 1900.

Lemna scutata Dawson. Lesquereux, U. S. Geol. Survey Terr. Rept., vol. 7, p. 102, pl. 61, fig. 5, 1878 [not fig. 2, which is Nelumbo dawsoni Hollick].

The types of this species, from Point of Rocks, Wyo., are represented as somewhat smaller than the specimens here figured. However, on the back of the block containing specimen 547, there is an unillustrated specimen that approximates the size of figure 9. In Knowlton's discussions of both Pistia corrugata and Ottelia americana he considers the suggestion of uniting these species, but refrains from doing so. Ottelia americana is only a distorted, imperfectly preserved specimen of Pistia corrugata. One of Lesquereux's specimens of Lemna scutata, as cited, belongs with Pistia corrugata, being only a small leaf of that species.

Pistia corrugata is a larger species than $P$. nordenskiöldi (Heer) Berry, ${ }^{14}$ from the Cretaceous Black Creek formation of North Carolina, and is distinguished by the presence of a conspicuously corrugated border that surrounds the smooth central portion.

Occurrence: Colgate member, locality 4269, Glendive, Mont. (pl. 49, figs. $7-9$; pl. 56, fig. 6a). Fox Hills sandstone, locality 5436 , S. Dak.

\section{FAGACEAE}

\section{Dryophyllum subfalcatum Lesquereux}

Plate 50, figures 1-8; plate 51, figures $1-7,8$; plate 52 , figures $1-3$, plate 54, figure 1

Dryophyllum subfalcatum Lesquereux, U. S. Geol. and Geog. Survey Terr. Bull., vol. 1, p. 379, 1875 [1876]; U. S. Geol. Survey Terr. Rept., vol. 7, p. 163, pl. 63, fig. 10, 1878.

Knowiton, Geol. Survey Bull. 163, p. 41, 1900.

Dryophyllum bruneri Ward, Geol. Survey Bull. 37, p. 27, pl. 10, figs. 5-8, 1887 .

Knowlton, Geol. Survey Prof. Paper 101, p. 259, pl. 53, fig. 5, 1917.

Hollick, Geol. Survey Prof. Paper 159, p. 70, pl. 38, figs. 2, 1930.

Dryophyllum aquamarum Ward, Geol. Survey Bull. 37, pl. 10, figs. 2-4, 1887.

Dryophyllum falcatum Ward, idem, p. 27, pl. 11, fig. 1.

Kinowlton, Geol. Survey Bull. 163, p. 42, pl. 8, fig. 1, 1900.

Quercus gracilis Newberry, Geol. Survey Mon. 35, p. 75, pl. 67, fig. 4,1898 .

Quercus whitmani Knowlton, Geol. Survey Prof. Paper 155, p. 52, pl. 17, fig. 5, 1930.

Quercus turbulenta Hollick, Geol. Survey Prof. Paper 159, p. 70, pl. 38, fig. 3,1930 .

14 Berry, E. W., Contributions to the Mesozoic flora of the Atlantic Coastal Plain, V, North Carolina: Torrey Bot. Club Bull., vol. 37, p. 189, pl. 21, figs. 1-15, 1910.
Fraxinus leei Berry, Geol. Survey Prof. Paper 185-F, p. 132, pl. 25, figs. 1-5, 1934; Canada Geol. Survey Mem. 182, p. 55 , pl. 15 , fig. 4,1935 .

The numerous new figures given here amend the concept of this species by illustrating variations of size, shape, and venation. Figures 2 and $8 \mathrm{~b}$ of plate 51 illustrate forms with entire margins and accompanying dislocation of the secondary venation, which becomes strongly camptodrome and includes a number of intermediaries that do not reach the margin. These leaves are very abundant in the Colgate member and Hell Creek formation at the locality $1 \frac{1 / 2}{2}$ miles southwest of Glendive, Mont.

Occurrence: Colgate member, Jocality 4269, Glendive, Mont. (pl. 50, figs. 1-8; pl. 51, figs. 1-7; pl. 54, fig. 1). Fox Hills sandstone, locality 5436, S. Dak. (pl. 51, fig. 8b). Hell Creek formation, locality 8197, Glendive, Mont. (pl. 52, figs. 1-3).

\section{MORACEAE}

\section{Ficus ceratops Knowlton}

Plate 61, figures 1-14

Palmocarpon sp. Stanton and Knowiton, Geol. Soc. America Bull., vol. 8, p. 136, 1897.

Ficus ceratops Knowlton, Torrey Bot. Club Bull., vol. 38, p. 389 , figs. 1-4, 1911.

Berry, Canada Geol. Survey Mem. 182, p. 28, 1935. [See discussion.]

Ficus russelli Knowiton, Torrey Bot. Club Bull., vol. 38, p. 392, 1911.

These specimens are remarkably figlike in appearance. Unfortunately they are casts composed of sand and clay, and cross sections (fig. 2) therefore show no internal structure. Only external characters are available as aids to identification. In the best-preserved specimens the striations around the neck are especially prominent and regular, and in some there appear to be remains of a collar or sheath around the neck. These facts excite in me the suspicion that, although figlike leaves have been found with the "figs," these fossils may belong to an entirely different group. For example, fossils not greatly dissimilar in size and appearance have been correctly identified as the underground tubers of horsetails (Equisetum). Thus Heer ${ }^{15}$ records Equisetum arcticum, with large tubers, from Spitsbergen. It seems difficult, without Heer's specimens in hand, to distinguish between them and some of the specimens figured here. Berry ${ }^{16}$ also reports $E$. arcticum, with large tubers, from the Cretaceous of Saskatchewan and suggests that these tubers may have been on the bill of fare of Triceratops and other dinosaurs.

With this problem in mind I searched the beds yielding "figs" for evidence as to probable relationship of the "figs" to Equisetum. I found no "figs" grouped in

${ }^{15}$ Heer, Oswald, Flora fossilis aretica, vol. 2, pt. 3, p. 31, pl. 1, figs. 1-15; pl. 2, figs. $1-4,1870$.

16 Berry, E. W., The food value of an Equisetum from the Lance formation of Saskatchewan: Canadian Field-Naturalist, vol. 38, pp. 131, 132, fig. 1, 1924. 
a whorl around a stem or in a chain; all were detached. I found several striated impressions (pl. 61, fig. 14) that may be underground Equisetum stems, but, as no sheaths are present, this identification must be considered tentative.

The tubers of Eocene and later equisetums are much more finely striated than the Cretaceous species. Living species may be covered with fine hairs.

The specimens figured here were collected from a bed in the Hell Creek formation exposed halfway up the bluffs overlooking Bug Creek, a tributary of Big Dry Creek, 40 miles northwest of Circle, Mont. Dinosaur and turtle bones are especially abundant in these strata. Other localities yielding "figs" in the Hell Creek formation or its equivalents are Converse County, Wyo., the bluffs opposite (south of) Forsyth, Mont., and Graveyard Coulee, opposite (south of) Glendive, Mont. This species, therefore, appears to have been widespread, but limited in vertical geologic range.

Occurrence: Hell Creek formation, locality 8514, Circle, Mont.

Ficus preartocarpoides Brown, n. sp.

Plate 53, figures 3-5

Ficus artocarpoides Lesquereux. Knowlton, Washington Acad. Sci. Proc., vol. 11, p. 185, 1909.

Leaves small to large, as much as 18 centimeters or more long, elongated ovate with pointed apex and subcordate or somewhat auriculate base. Margins entire or with scattered short blunt lobes or stout acute lobes entered by strong secondary veins (fig. 3), thus giving the leaves the appearance of being related to those called Artocarpus pungens (Lesquereux) Hollick ${ }^{17}$ from Golden, Colo. Secondary venation pinnate, the veins being somewhat undulate, abruptly camptodrome close to the margin unless entering a large tooth or lobe, and much branched in the lower half of the leaf, some branches leaving the secondary halfway between the midrib and the margin. Tertiary venation composed of numerous evenly spaced diagonal veinlets.

These are the leaves identified by Knowlton as Ficus artocarpoides in the collection made by Barnum Brown from Hell Creek strata on Big Dry Creek in northeastern Montana. They differ, however, from Lesquereux's types of that species in having more attenuate apexes, longer and more acute marginal lobes when these are present, and more undulatory, branched secondaries, as well as in originating from an earlier formation. Nevertheless the two species are so similar that a close relationship is indicated.

The comparison of Ficus preartocarpoides with $F$. artocarpoides developed the following preliminary synonymy for the latter species, the types of which, according to Lesquereux's statement of occurrence,

17 Lesquereux, Leo, The Cretaceous and Tertiary floras: U. S. Geol. Survey Terr Rept., vol. 8, p. 123, pl. 19, figs. 3, 4, 1883 . came from "Badlands, N. Dak."-a somewhat indefinite reference but evidently the Fort Union formation, to judge by the associated species collected by Prof. William Denton from the same general area.

Ficus artocarpoides Lesquereux, U. S. Geol. Survey Terr. Rept., vol. 8 , p. 227, pl. 47 , figs. 1-5, 1883.

Quercus platania Heer. Dawson, Roy. Soc. Canada Trans., vol. 7 , p. 72 , pl. $11,1889$.

Quercus dawsoni Knowlton, Geol. Survey Bull. 152, p. 191, 1898. Protophyllum sp. Berry, Roy. Soc. Canada Trans., vol. 20, sec. 4, p. 194, fig. 1, 1926.

Protophyllum canadensis Berry, Canada Geol. Survey Mem. 182 , p. 31 , pls. 4 B, 5, 1935 .

Pterospermites penhallowi Berry, idem, p. 49, pl. 13.

That Ficus preartocarpoides and $F$. artocarpoides are figs or even related to figs is doubtful but not improbable, inasmuch as supposed figlike fruits called $F$. ceratops, described above, have been found in the same strata. Whatever their true botanic affinities may be, these leaves are readily identifiable, and $F$. preartocarpoides, found at nearly every fossil-plant locality in the higher strata of the Hell Creek formation in North Dakota and Montana, is an indicator for that horizon in that area.

Occurrence: Hell Creek formation, locality 8242, Marmarth, N. Dak. (figs. 3-5); locality 8514, Circle, Mont.; bluffs opposite (south of) Forsyth, Mont.

\section{PLATANACEAE}

Platanus sp.

Plate 59, figures 4, 5

These specimens are referred with some hesitation to Platanus, but provisionally they may be so assigned, until a thorough revision of the Cretaceous and Eocene species of Platanus has been made.

Occurrence: Fox Hills sandstone, locality 5436 , S. Dak.

\section{TROCHODENDRACEAE}

Trochodendroides sp.

Plate 48, figures $19-22$

These lanceolate or elliptic leaves with serrate margins are a species of Trochodendroides, but I am not prepared to name the species now, it being my purpose to review the entire genus at length in another place.

Occurrence: Colgate member, locality 8564, Glendive, Mont. (figs. 20-22). Hell Creek formation, locality 8242, Marmarth, N. Dak. (fig. 19).

\section{Trochodendroides sp.}

Plate 48 , figure 23

This, like the preceding species, will receive specific treatment in another place.

Occurrence: Hell Creek formation, locality 8197, Glendive, Mont. 


\section{LAURACEAF}

\section{Cinnamomum affine Lesquereux}

Plate 53, figures 1, 2

Cinnamomum affine Lesquereux. Knowlton, Geol. Survey Bull. 696, p. 168, 1919. (See synonymy and note.)

The fragmentary condition of these leaves raises doubts as to whether they should be assigned to Cinnamomum affine, C. lanceolatum, or C. laramiense. Pending a restudy of the Cretaceous species of $\mathrm{Cin}$ namomum and related lauraceous genera, they may as well remain as $C$. affine.

Occurrence: Colgate member, locality 4269, Glendive, Mont.

\section{Laurus lanceolata Knowlton}

Plate 53, figure 6

Laurus lanceolata Knowlton, Geol. Survey Prof. Paper 130, p. 143, pl. 21, fig. 7, 1922; Geol. Survey Prof. Paper 155, p. 85 , pl. 38, fig. 9, 1930 .

Knowlton unwittingly described this species twice as a new species; but, regardless of this lapse, it is a testimony to his recognition of identical characters that he should have given the same specific name to the two type specimens. They came from different localities in the Laramie and Denver formations, in the Denver Basin, Colo.

Occurrence: Colgate member, locality 4269, Glendive, Mont.

Sassafras montana Brown, n. sp.

Plate 52, figure 4 ; plate 55, figure $4 \mathrm{~b}$

Leaves 8 centimeters or more wide, three-lobed, the lobes relatively short, blunt-rounded; sinuses narrow, rounded; base cuneate; petiole 5 centimeters long. The lateral primary veins depart from the midrib 0.5 centimeter above the top of the petiole and after running a fairly straight course pass into the two lateral lobes. The secondary venation is camptodrome.

The chief difference between this and the well-known Sassafras cretaceum Newberry and its many forms from the Dakota sandstone is that the sinuses of S. montana are smaller and sharper, and there is a tendency for the lateral lobes to show an incurving toward the top of the middle lobe.

Occurrence: Hell Creek formation, locality 8197, Glendive, Mont. (pl. 52, fig. 4); locality 8242, Marmarth, N. Dak. (pl. 55, fig. $4 \mathrm{~b})$.

\section{NYMPHAEACEAE}

\section{Nelumbo dawsoni Hollick}

Plate 48, figure 11

Brasenia antiqua Dawson, Royal Soc. Canada Trans., vol. 3, sec. 4, p. 15, text fig., 1885 [1886].

Nelumbo dawsoni Hollick, Torrey Bot. Club Bull., vol. 21, p. $309,1894$.
Berry, Canada Geol. Survey Mem. 182, p. 36, pl. 7, fig. 1, 1935. (See synonymy and discussion.)

Lemna scutata Dawson. Lesquereux, U. S. Geol. Survey Terr. Rept., vol. 7, p. 102, p]. 61, fig. 2, 1878.

Nelumbo laramiensis Hollick, Torrey Bot. Club Bull., vol. 21, p. 307, text fig., 1894.

Nelumbo intermedia Knowlton, Geol. Survey Bull. 163, p. 53, pl. 13, figs. 3-5, 1900 .

In Knowlton's discussion ${ }^{18}$ of the several fossil species of Nelumbo cited in this synonymy, he was disposed to regard them as separate species, chiefly on the basis of differences in the number of radial veins. Nelumbo dawsoni from the Belly River series at Medicine Hat, Alberta, has 18 veins; $N$. laramiensis from "the Laramie group at Florence, Colo.," has 12 veins; $N$. intermedia from the Montana group at Point of Rocks, Wyo., has 12 to 17 veins; and the specimen figured here from the Colgate sandstone at Glendive, Mont., has 11 veins in the preserved portion, the total for the entire leaf probably having been 17 or 18

After counting the veins in numerous leaves of the American lotus, Nelumbo lutea, and of the East Indian lotus, $N$. nucifera, in the U. S. National Herbarium, I conclude that the number of veins is not significant for identifying a single specimen. In $N$. lutea the number varies from 18 to 25 , with 22 as an average; in $N$. nucifer $a$ the average is 20 . If an abundance of material were available so that an average might be ascertained, such average would probably have specific significance. As the fossil material is scanty, and as the variation in number of veins is of the same order as that in living species, I think there is justification in regarding these small leaves as a single Upper Cretaceous species.

Brasenia, now a monotypic genus, has elliptic, peltate leaves with an average of 15 radial veins. It is not improbable that Nelumbo dawsoni may have been a species of Brasenia.

Occurrence: Colgate member, locality 4269, Glendive, Mont.

\section{Paranymphaea hastata Brown, n. sp.}

Plate 52, figures 5, 6a

Leaves sagittate, the basal lobes rounded; apex not preserved in these specimens; venation pinnate, the secondaries camptodrome, with few intermediaries; lowest secondaries to the basal lobes branched.

These leaves resemble some species of Aristolochia, Polygonum, and other genera, but I suspect that they belong to a water-lily species that was perhaps a forerunner of the well-known Fort Union species, Paranymphaea crassifolia (Newberry) Berry.

Occurrence: Fox Hills sandstone, locality 5436, S. Dak.

18 Knowlton, F. H., The flora of the Denver and associated formations of Colorado: Geol. Survey Prof. Paper 155, pp. 88-91, 1930. 


\section{MAGNOLIACEAF}

\section{Lirıodendron sp.}

Plate 52, figure 7

This leaf has a pinnate venation somewhat resembling that in Liriodendron marcouanum (Heer) Knowlton ${ }^{19}$ and other Upper Cretaceous species. Unfortunately the tip is not preserved, so that reference of the specimen to any named species does not seem appropriate.

Occurrence: Colgate member, locality 4269, Glendive, Mont.

\section{Magnolia lakesii Knowlton}

Plate 54, figure 5

Magnolia lakesii Knowlton, Geol. Survey Prof. Paper 130, p. 142, pl. 13, fig. 2, 1922.

This specimen appears to be a very close match to the type, but its reference to Magnolia is not entirely satisfactory.

Occurrence: Colgate member, locality 4269, Glendive, Mont.

Magnolia nervosa (Knowlton) Brown, n. comb.

Plate 54, figures 3, 4

Pterospermites nervosum Knowlton, Geol. Survey Prof. Paper 101, p. 273 , pl. 48 , fig. $4,1917$.

Except for what appears to be an abnormality in the secondary venation near the base of the type specimen from the Vermejo formation, there seems to be little difference between that specimen and those figured here. The secondary venation in these leaves is characterized by its conspicuous forking. The reference to Magnolia is unsupported by fossil fruits.

Occurrence: Colgate member, locality 4269, Glendive, Mont. Hell Creek formation, locality 8197, Glendive, Mont. (figs. 3, 4).

\section{ANONACEAE}

Anona robusta Lesquereux

Plate 54, figure 2

Anona robusta Lesquereux, U. S. Geol. Survey Terr. Rept., vol. 8, p. 124, pl. 20, fig. 4, 1883.

Knowlton, Geol. Survey Prof. Paper 130, p. 143, pl. 17, fig. 7, 1922.

It is with considerable hesitation that I assign the leaf figured here to this species. The specimen might, with equal propriety, have been called Ficus uncata Lesquereux, as reported by Knowlton ${ }^{20}$ from the Raton formation, or Ficus arenacea Lesquereux, as reported by Knowlton ${ }^{21}$ from the Laramie of the Denver Basin; but as all these leaves are fragmentary and poorly preserved it is doubtful whether they can be classified botanically with any satisfaction.

Occurrence: Hell Creek formation, locality 8197, Glendive, Mont.

is Knowlton, F. H., A catalogue of Mesozoic and Cenozoic plants of North America: Geol. Survey Bull. 696, p. 360, 1919. (See synonymy.)

${ }^{20}$ Knowlton, F. H., Fossil floras of the Vermejo and Raton formations of Colorado and New Mexico: Geol. Survey Prof. Paper 101, p. 300, pl. 76, fig. 2, 1917.

21 Knowlton, F. H., The Laramie flora of the Denver Basin, with a review of the Laramie problem: Geol. Survey Prof. Paper 130, p. 140, pl. 10, fig. 2, 1922.

\section{TILIACEAE}

Grewiopsis saportana Lesquereux

Plate 55, figures $1-3,4 \mathrm{a}$

Aleurites eocenica Lesquereux, U. S. Geol. and Geog. Survey Terr., 6th Ann. Rept., p. 397, 1872 [1873].

Grewiopsis saportana Lesquereux, U. S. Geol. Survey Terr. Rept., vol. 7, p. 257, pl. 50, figs. 10-12, 1878.

Grewiopsis ficifolia Ward, Geol. Survey Bull. 37, p. 92, pl. 41, figs. 1, 2, 1887.

Grewiopsis eocenica (Lesquereux) Knowlton, Geol. Survey Bull. 152 , p. 114, 1898.

The longer leaves of this species tend to be lanceolate, and the smaller ones elliptic or ovate. Margin denticulate or serrate with glandular mixed hooked teeth, the spaces between the teeth being conspicuously scalloped. Venation pinnate, the curving secondaries entering marginal teeth or sending branches to those teeth. There is a tendency toward palmateness in that the lowermost secondaries are generally strongest and have numerous lateral branches to adjacent marginal teeth. The tertiary venation consists of evenly spaced more or less diagonal veinlets. Base cuneate. Petiole 3-5 centimeters long.

The specimens described by Lesquereux and Ward came from Black Buttes, Wyo.; those figured here came from Marmarth, N. Dak. The latter differ from the former chiefly in having more conspicuously toothed margins.

These leaves are not to be confused with somewhat similar leaves called Celastrus. The latter have dentate nonglandular teeth and the interspaces are not scalloped; they are widest medianly; their secondary veins are about equally spaced and the lowermost show no tendency toward palmateness.

The original name for this species was eocenica, but in 1878 Lesquereux changed the name to saportana because he thought eocenica was inappropriate "as all the species of Grewiopsis known until now are Eocene." There are three reasons why the name eocenica should not be used: (1) The original description of the species was not accompanied by an illustration, (2) Lesquereux desired and made a substitution, and (3) the term eocen$i c a$ is misleading because the specimens come from Cretaceous strata.

Occurrence: Hell Creek formation, locality 8242, Marmarth, N. Dak.

\section{SAPINDACEAE}

Sapindus cretaceus Brown, n. sp.

Plate 55, figures 9, 10; plate 57, figure $7 \mathrm{~b}$

Leaflets lanceolate, more or less unsymmetrical, with entire margins; secondary venation pinnate, camptodrome; petioles 3 to 4 millimeters long.

These leaves are referred with considerable hesitation to Sapindus, but they seem to belong to the same category as the leaves from succeeding formations called Sapindus affnis and $S$. grandifoliolus and may be ancestral to them. They resemble the Upper Cre- 
taceous species S. morrisoni (Lesquereux) Heer, reported by Hollick ${ }^{22}$ from Alaska.

Occurrence: Hell Creek formation, locality 8197, Glendive, Mont.

\section{VITACEAE}

\section{Cissites colgatensis Brown, n. sp.}

Plate 55, figures 5-7

Leaves broadly ovate, small, lobed; lobes ovate, with elongated tips; sinuses rounded, open; base horizontal; margin entire. A pair of primary veins, rising from the top of the petiole, flanks the midrib; secondaries branch from the primaries to the lobes; petiole at least 1 centimeter long.

This species is distinguished by its smaller size and less deeply cut lobes from the Vermejo species, Cissites panduratus Knowlton. ${ }^{23}$

I have some suspicion that these leaves may be merely lobed forms of Dombeyopsis colgatensis, described elsewhere in this paper.

Occurrence: Colgate member, locality 4269, Glendive, Mont.

\section{Cissites panduratus Knowlton}

Plate 55, figure 8

Cissites panduratus Knowlton, Geol. Survey Prof. Paper 101, p. 274, pl. 49, fig. 10, 1917.

This specimen differs from the type chiefly in having a slightly auriculate base. It may be identical with Cissites formosus Heer, from Atanekerdluk, Greenland.

Occurrence: Hell Creek formation, locality 8197, Glendive, Mont.

\section{Vitis stantoni (Knowlton) Brown, n. comb.}

Plate 56, figures $1-5,6 \mathrm{~b}$; plate 57 , figures $1-6$, $7 \mathrm{a}$; plate 58 , figures 1-4; plate 59, figure 6

Castalia stantoni Knowlton, Geol. Survey Bull. 257, p. 147, pl. 19, fig. 4, 1905.

Vitis dakotana Berry, Geol. Survey Prof. Paper 185-F, p. 130, pl. 26, figs. 4-6; pl. 27, 1934.

Berry, Canada Geol. Survey Mem. 182, p. 47, pl. 12, figs. $1,2,1935$

Vitis vulpinum Knowlton, Geol. Survey Prof. Paper 98-H, p. 92, pl. 18, fig. 1, 1916.

The Judith River specimen, Castalia stantoni Knowlton, is patently not a Castalia. It has, however, the characters of Vitis, and is therefore combined as such. The specimens here reproduced from the Colgate sandstone and the Hell Creek formation just above show great variation in size, form, and development of marginal dentition. In the last-named character the margins may be merely undulate-toothed, as in the type and in the specimen shown in plate 56 , figure 5 , or the teeth may be strongly developed, as shown in plate 58 , figure 4, and in Berry's plate 27. I consider, therefore,

${ }_{22}$ Hollick, Arthur, The Upper Cretaceous floras of Alaska: Geol. Survey Prof. Paper 159, p. 100, pl. 78, fig. 1, 1930.

${ }^{23}$ Knowlton, F. H., Fossil floras of the Vermejo and Raton formations of Colorado and New Mexico: Geol. Survey Prof. Paper 101, p. 274, pl. 49, fig. 10, 1917. that we are here dealing with a single Upper Cretaceous species.

Occurrence: Fox Hills sandstone, locality 4143, Glendive, Mont. (pl. 58, figs. 3, 4; pl. 59, fig. 6). Colgate member, locality 4269, Glendive, Mont. (pl. 56, figs. 1, 2, 4, 5, 6b; pl. 57, figs. 1-5). Hell Creek formation, locality 8197, Glendive, Mont. (pl. 56, fig. 3 ; pl. 57, figs. $6,7 \mathrm{a}$; pl. 58, figs. 1,2 ).

\section{CORNACEAE}

\section{Cornus praeimpressa Knowlton}

Plate 55, figure 11

Cornus praeimpressa Knowlton, Geol. Survey Prof. Paper 130 , p. 159, pl. 14, fig. 5; pl. 19, fig. 2a, 1922.

The leaf figured here appears to represent the species described by Knowlton from the Laramie of the Denver Basin.

Occurrence: Colgate member, locality 4269, Glendive, Mont.

\section{EBENACEAE}

\section{Diospyros berryana Knowlton}

Plate 55, figure 12

Diospyros berryana Knowlton, Geol. Survey Prof. Paper 130. p. 161 , pl. 17, fig. 5,1922 .

Except that the leaf figured here is smaller than the type there seems to be little difference between them.

Occurrence: Colgate member, locality 4269, Glendive, Mont.

\section{CAPRIFOLIACEAE}

Viburnum marginatum Lesquereux

Plate 59, figure 7

Viburnum marginatum Lesquereux, U. S. Geol. Survey Terr. Rept., vol. 7, p. 223, pl. 38, fig. 1, 1878. [No other figures or citations are given here, pending a revision of this Upper Cretaceous species.]

The specimen figured here matches the type almost exactly. This appears to be one of the diagnostic species of the late Upper Cretaceous in this area.

Occurrence: Hell Creek formation, locality 8518, Glendive, Mont.

\section{BIGNONIACEAE}

Dombeyopsis colgatensis Brown, n. sp.

Plate 60, figures 1-4

Mature leaves broadly ovate, almost deltoid, with elongated blunt apex and subcordate base; other leaves ovate, with rounded, narrow apex and cuneate base; petiole 1 centimeter long. Flanking the midrib is a pair of primary veins rising from the top of the petiole and curving sharply upward toward the apex. The first secondary veins of consequence depart from the midrib in the upper third of the leaf; those from the primaries form conspicuous loops in the outer lateral portions of the leaf. Margins are entire but in some specimens appear undulate. 
The fossil species most closely resembling Dombeyopsis colgatensis appears to be $D$. obtusa Lesquereux, ${ }^{24}$ which, however, has a much rounded apex. Superficially, these leaves also resemble described fossil species of Aristolochia, Ficus, and Populus, but the reference of them to any of these genera would probably be no more satisfactory than to Dombeyopsis.

Occurrence: Colgate member, locality 4269, Glendive, Mont.

\section{FOSSILS OF UNCERTAIN BOTANIC AFFINITY}

Calycites sp.

Plate 61 , figures 20,21

These are apparently calyces with fringed borders. Somewhat similar fossils from the Fox Hills sandstone near Milliken, Colo., were described by Knowlton as Phyllites cockerelli. ${ }^{25}$

Occurrence: Colgate member, locality 4269, Glendive, Mont.

Phyllites sp.

Plate 51, figure $8 \mathrm{a}$; plate 60 , figure 8

Leaves ovate-elliptic, with entire margins and cuneate bases; venation pinnate, rather closely spaced, camptodrome.

I have no suggestion as to the botanic affinity of these leaves.

Occurrence: Fox Hills sandstone, locality 5436, S. Dak. (pl. 51, fig. 8a). Hell Creek formation, locality 8197, Glendive, Mont. (pl. 60, fig. 8).

\section{Phyllites sp.}

Plate 60, figures 5-7

Leaves apparently ovate, with entire margins and cordate bases; venation pinnate, camptodrome.

I have no suggestion as to the botanic affinity of these leaves.

Occurrence: Colgate member, locality 4269, Glendive, Mont.

\section{Carpolithus hirsutus Newberry}

Plate 61 , figures $17-19$

Carpolithus hirsutus Newberry, Geol. Survey Mon. 26, p. 134, pl. 146, figs. 14, 14a, 1895 [1896].

Hollick, Geol. Survey Mon. 50, p. 110, pl. 7, figs. 3-8, 1906. Carpolithus spinosus Newberry. Hollick, Geol. Soc. America Bull., vol. 7, p. 13, 1895 .

The only apparent difference between the specimens figured here and the specimens from the Cretaceous at Woodbridge, N. J., and Gay Head, Marthas Vineyard, is that the Montana specimens are somewhat larger. They occur in a carbonaceous shale with the comminuted fragments of ferns and dicotyledonous plants. I have no suggestion as to their botanic affinity.

Occurrence: Hell Creek formation, locality 8531, Glendive, Mont.

24 Lesquereux, Leo, The Tertiary flora: U. S. Geol. Survey Terr. Rept., vol. 7 p. 255, pl. 47, figs. 4, 5, 1878; Knowlton, F. H., The Laramie flora of the Denver Basin: Geol. Survey Prof. Paper 130, pl. 162, pl. 13, fig. 4; pl. 20, fig. 11; p. 27, figs. 1-4, 1922.

${ }^{25}$ Knowlton, F. H., The flora of the Fox Hills sandstone: Geol. Survey Prof. Paper 98-H, p. 93, pl. 17, figs. 5, 6, 1916.

\section{Coniferous seed}

Plate 48 , figure 5

In the absence of confirmatory foliage it is a matter of conjecture whether the seed figured here should be referred to Pinus, Abies, Picea, or some other coniferous. genus. The only coniferous foliage associated with it is that of Sequoia, to which obviously the seed does not belong.

Occurrence: Hell Creek formation, locality 8242, Marmarth, N. Dak.

\section{Carpolithus sp.}

Plate 61, figures 22-25

Casts of fruits, 3 to 4 centimeters long, smooth, ovate, pointed, at least 2 - if not 4-valved, somewhat compressed and presenting a rounded rectangular transverse section. The section shows no internal structure, being merely the ferruginous mud filling of the cavity formerly occupied by the fruit. Figure 22 shows remains of truncated, lateral flanges on both sides of the apex.

I have no suggestion as to the botanic affinity of these fruits, although somewhat similar fossils have been called Palmocarpon. They resemble the seeds of Artocarpus in shape but are apparently much too large.

Occurrence: Hell Creek formation, locality 8260, Circle, Mont.

Carpolithus sp.

Plate 61, figures 15,16

These irregularly rounded casts of fruits are not uncommon. That they are the seeds of Ginkgo is one possibility, but they do not have the shape of modern Ginkgo seeds.

Occurrence: Colgate member, locality 4269, Glendive, Mont. (fig. 15); Hell Creek formation, locality 8197, Glendive, Mont. (fig. 16).

\section{Halymenites major Lesquereux}

Plate 62, figures 1-7; plate 63 , figures 1,2

Halymenites major Lesquereux, U. S. Geol. and Geog. Survey Terr. Ann. Rept., 1872, p. 373, 390, 1873; U. S. Geol. Survey Terr. Rept., vol. 7, p. 38, pl. 1, figs. 7, 8, 1878.

Knowlton, Geol. Survey Bull. 163, p. 17, 1900; Geol. Survey Prof. Paper 98, p. 87, 1916; Geol. Survey Prof. Paper 101, p. 243, 1918.

Berry, Torrey Bot. Club Bull., vol. 43, p. 303, 1916.

Halymenites minor? Fischer-Ooster. Lesquereux, U. S. Geol. and Geog. Survey Terr. 6th Ann. Rept., p. 373, 1872 [1873]; U. S. Geol. Survey Terr. Rept., vol. 7, p. 39, pl. 1, fig. 9,1878 .

The outstanding fact about this supposed fossil seaweed is that it occurs in near-shore brackish-water or marine deposits and may be associated with marine fossils. Instead of being a diagnostic fossil of the Fox Hills sandstone, as was once believed, it is now known to occur in both older and younger formations and to have a widespread distribution, not only in the western interior but also in the Atlantic and Gulf Coastal Plain and South America. Its only stratigraphic significance is that it is indicative of a nearby shore zone. 
Other geological objects somewhat resembling Halymenites are ferruginous pipes and concretions that are produced by inorganic processes and weather out of sandstones; and tuberculated hot spring deposits around sticks, blades of grass, and the like, that can now be seen in process of formation in such run-off streams as those from the Mammoth Hot Springs in Yellowstone National Park. However, the pipes are generally simple, lacking the tubercles and extensive branching displayed by Halymenites. Moreover, when in place in their enclosing matrix, they are for the most part vertical, not horizontal or lying in every other conceivable position as does Halymenites. The occurrence of Halymenites in marine or brackish water deposits showing no other evidence of hot spring or similar action excludes such an explanation for its origin.

Comparison of Halymenites may also be made with the treelike alcyonarian corals called gorgonias, such as Gorgonia, Paragorgia, Primnoa, and Muricea. This group includes species that have branched, horny, or calcareous axes whose surfaces are studded with the raised or pitted calyces holding the polyps. They inhabit the relatively shallow waters in the vicinity of the West Indies and Florida Keys, but some species also occur in the deeper, cold waters of the Newfoundland Banks and Arctic seas. It is conceivable that the chitin or lime of a gorgonid axis, after burial in sediments, might be dissolved and sand or mud fill the cavity, the ultimate result being a cast of the original. If such was the origin of Halymenites, only fragments of an original coral colony have so far been collected, for no complete specimen showing the thickened "rootstock" has yet appeared. Furthermore, the tubercles of Halymenites do not show pits as they should if they represent the casts of gorgonid polyp calyces.

That Halymenites is a seaweed has not been proved by convincing evidence. On the contrary, information is accumulating to support the view that it may be the branching burrow of some marine animal. This information is as follows:

1. Transverse sections of a piece of Halymenites from the Fox Hills sandstone $3 \frac{1}{2}$ miles southwest of Marmarth, N. Dak. (pl. 62, figs. 6, 7), and one from the Nanjemoy formation near Popes Creek, Md., wharf (pl. 62, fig. 5), show that, when well preserved, these fossils consist of a central core filled with light-colored irregular pellets, which on analysis yield from 2 to 13 percent of phosphate radical $\left(\mathrm{PO}_{4}\right)$. This suggests that the pellets may be the droppings of an animal that inhabited the burrow. Surrounding the central core is a concentric crust of material, the outer surface of which may be strongly verrucose or tuberculated (pl. 62 , figs. 1, 3, 4). This tuberculation may have been produced by pressure of an animal from within a burrow or by direct emplacement of worked pellets. There is some indication that these surface tubercles were added row upon row as the structure developed.

2. The branching of Halymenites is most irregular, so that sometimes thick branches come off from thinner ones (pl. 62, fig. 3). Such deviations, although they may occur, are considered abnormalities in the plant kingdom. In Halymenites, however, they appear normal and suggest that it is not a plant.

3 . If a seaweed were large and substantial enough to resist crushing until the surrounding matrix in which it was buried became indurated, there should be some carbonized remains left. Thin leaves have left black carbonized imprints in the Colgate sandstone. Why should not large seaweeds have done likewise? Leaching, of course, may be called upon as the eliminating factor; or scavengers of one sort or another may have eaten out the seaweed, leaving the cavity to be filled with sand.

4. These branching forms may occur in the strata in any position-along the bedding planes, or vertically through the bedding planes, or diagonally in any direction (pl. 63, figs. 1, 2). The general impression these fossils give me in the field is that they were not originally objects at the mercy of the waves and sedimentary processes, as seaweeds would be, but that a purposeful builder was at work going in whatever direction seemed best.

The possibility that Halymenites may be the burrows made by crustaceans is not to be entertained lightly. Hayasaka ${ }^{26}$ figures plaster of paris casts of crab burrows from the beaches of northwestern Formosa (Taiwan) that seem to me very suggestive.

No animal remains of a sort that would identify the constructor of these postulated burrows have been found, but the possibility of finding such evidence should be kept in mind by field geologists and collectors.

\footnotetext{
Occurrence: Fox Hills sandstone (Cretaceous), 31/2 miles southwest of Marmarth, N. Dak. (figs. 1, 6, 7). Ripley formation (Cretaceous), near Enon, Bullock County, Ala. (fig. 4), collected by L. W. Stephenson. Nanjemoy formation (Eocene), Popes Creek, Md., wharf (figs. 2, 5), collected by F. S. MacNeil.
}

\footnotetext{
${ }^{26}$ Hayasaka, I., The burrowing activities of certain crabs and their geologic significance: Am. Midland Naturalist, vol. 16, pp. 99-103, 3 text figs., 2 pls., 1935.
} 


\section{PLATES 48-63}




\section{PLATE 48}

Figure 1. Asplenium tenellum Knowlton. Colgate member, locality $8564 \ldots \ldots \ldots$

2-4. Thuja colgatensis Brown, n. name. Colgate member, locality $8564 \ldots$

5. Coniferous seed. Hell Creek formation, locality $8242 \ldots \ldots \ldots$

6-10. Sequoia dakotensis Brown. Hell Creek formation, locality 6600 (figs. 6-8); locality 8242 (fig. 10); locality 8260 (fig. 9)

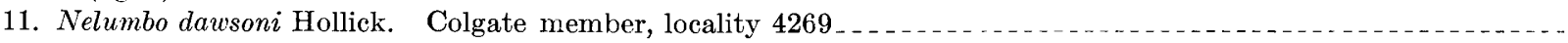

12-18. Ginkgo laramiensis Ward. Colgate member, locality 4269 (figs. 13-18); Hell Creek formation, locality 8197 (fig. 12)

23. Trochodendroides sp. Hell Creek formation, locality $8197 \ldots \ldots \ldots$

256 

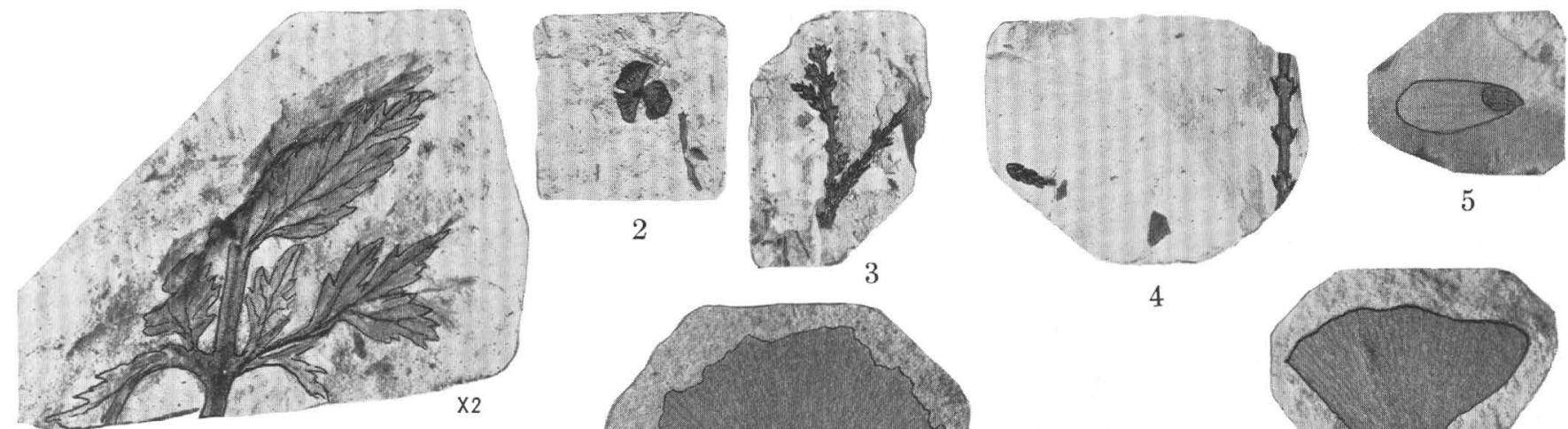

1

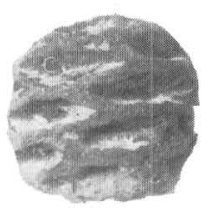

6

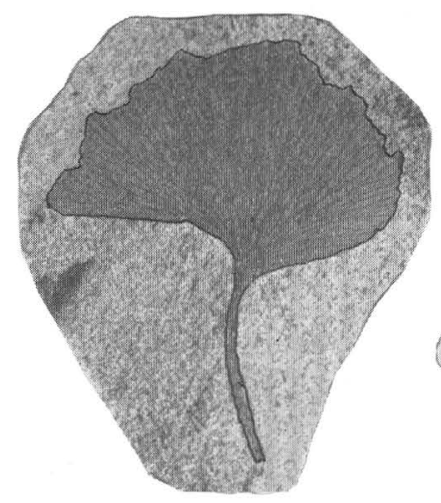

12
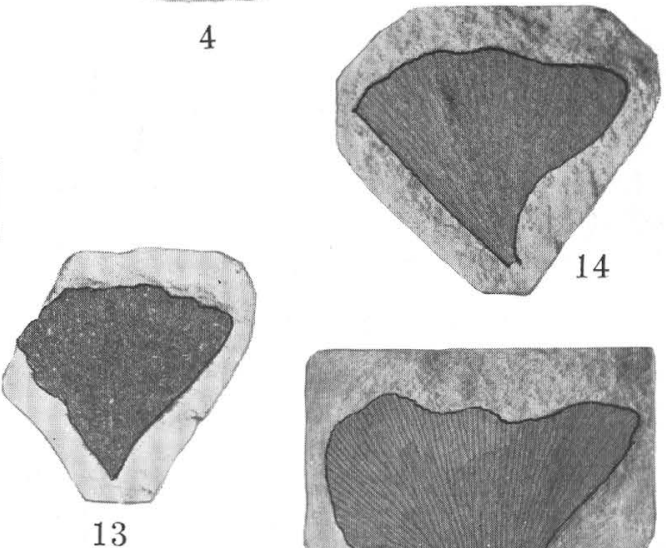

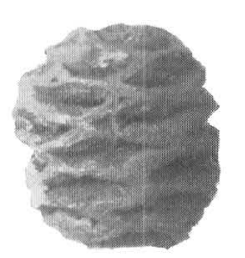

8

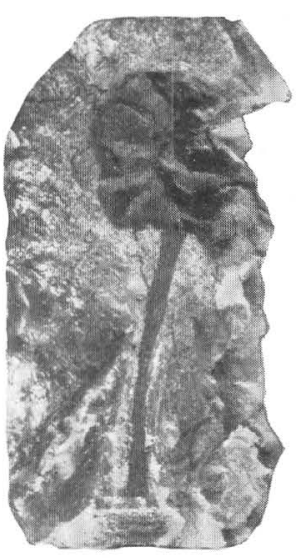

10

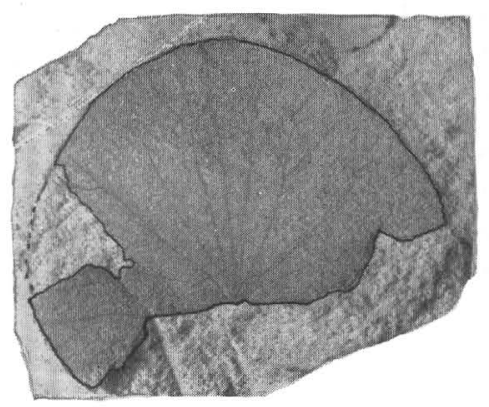

11

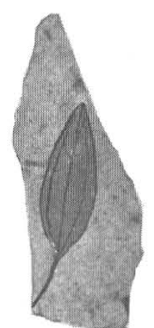

19

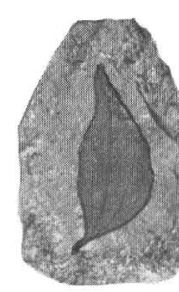

20

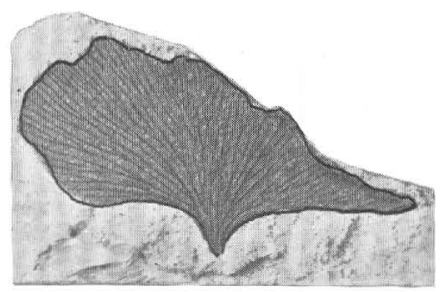

15
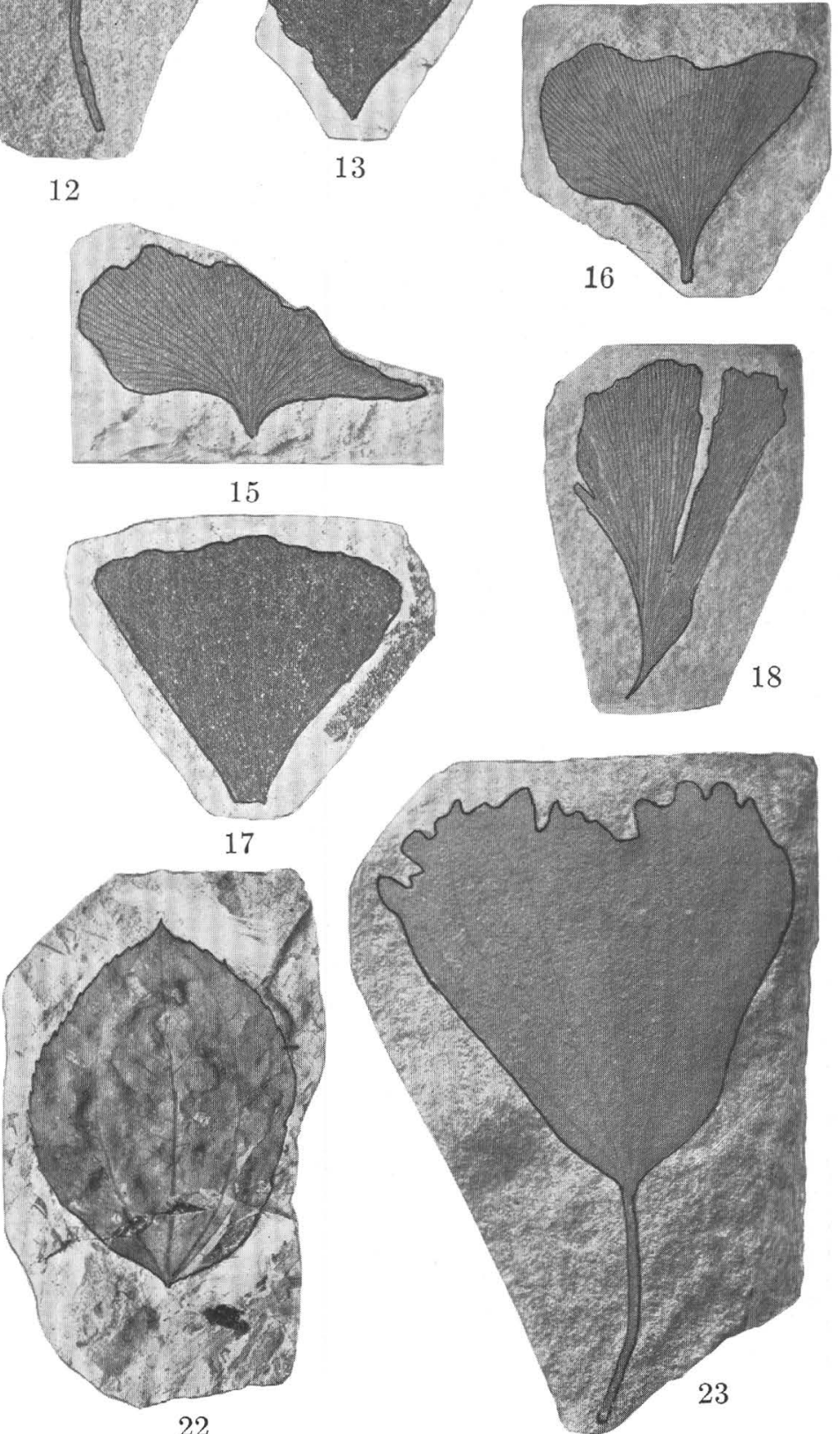

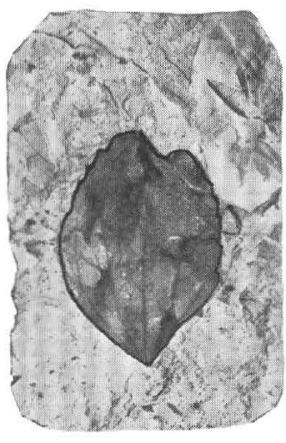

21 22

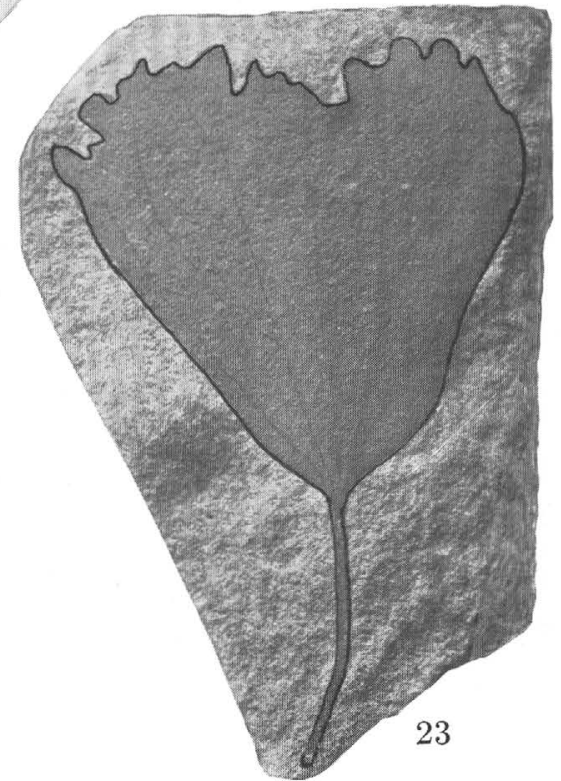

FOSSIL PLAN TS FROM THE COLGATE MEMBER OF THE FOX HILLS SANDSTONE AND ADJACENT STRATA 

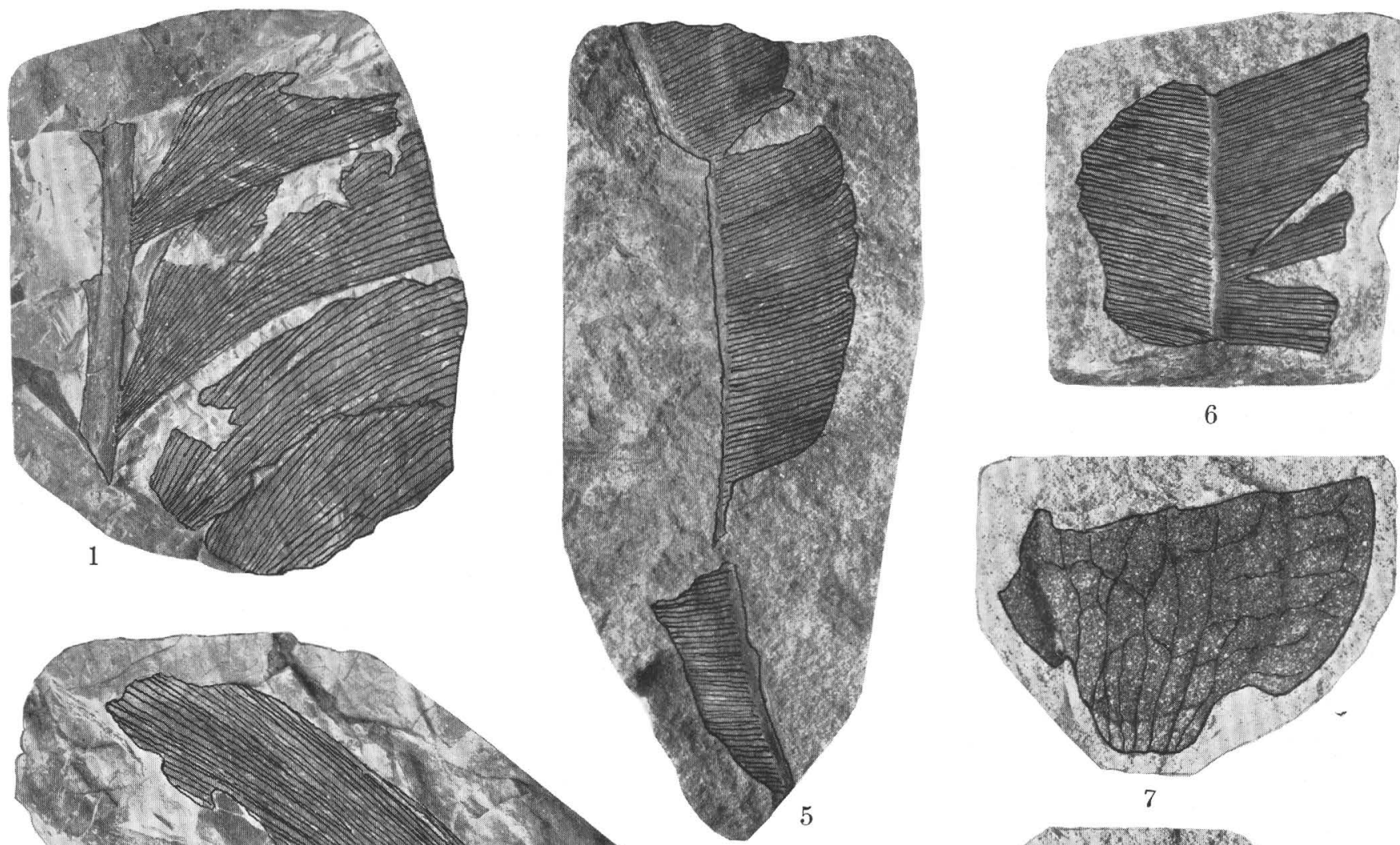

6

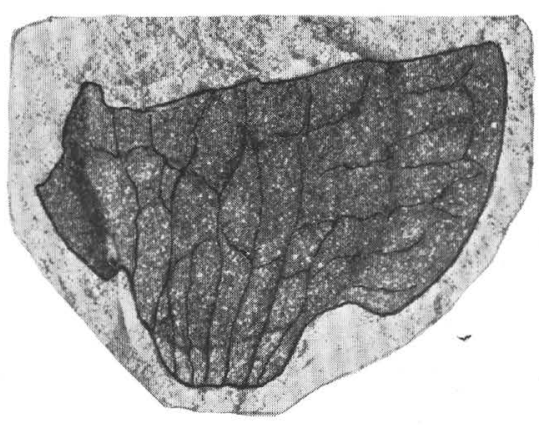

7

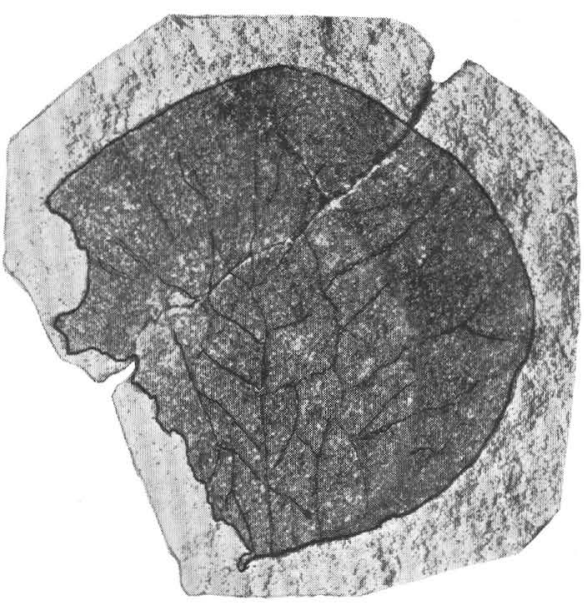

8
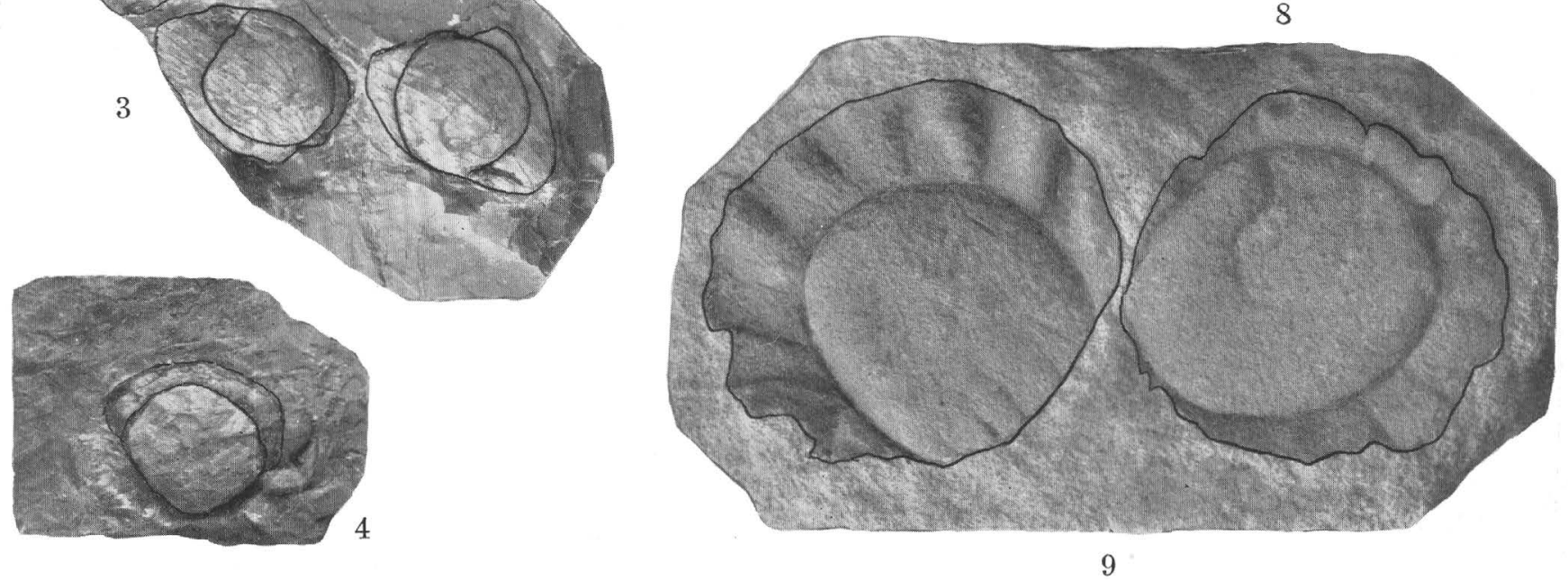

FOSSIL PLANTS FROM THE COLGATE MEMBER OF THE FOX HILLS SANDSTONE AND ADJACENT STRATA. 


\section{PLATE 49}

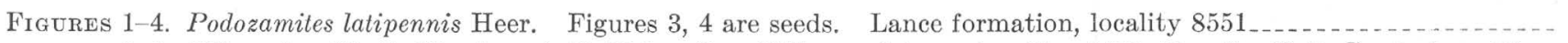
5, 6. Nilssonia gibbsii (Newberry) Hollick. Fox Hills sandstone, locality 5436 (fig. 6); Hell Creek formation, locality 4004 (fig. 5)

7-9. Pistia corrugata Lesquereux. Colgate member, locality 4269 
PLATE 50

Figures 1-8. Dryophyllum subfalcatum Lesquereux. Colgate member, locality $4269 \ldots$ 

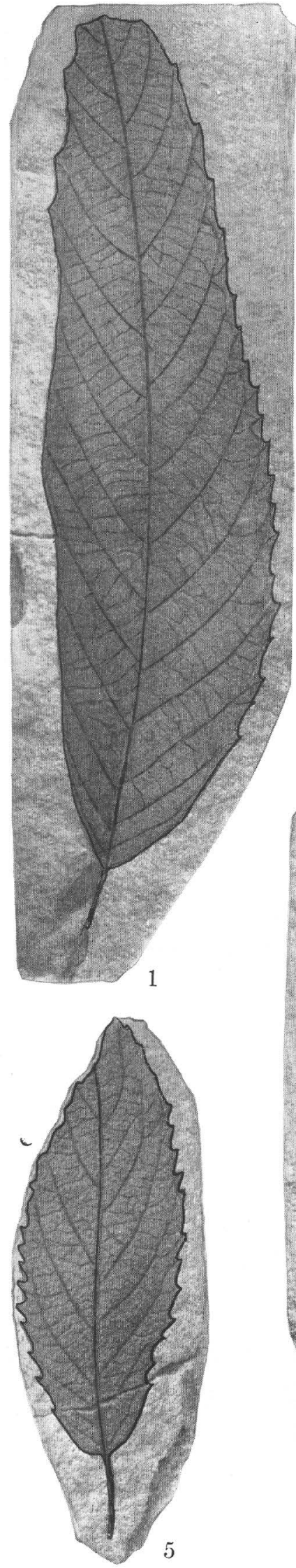

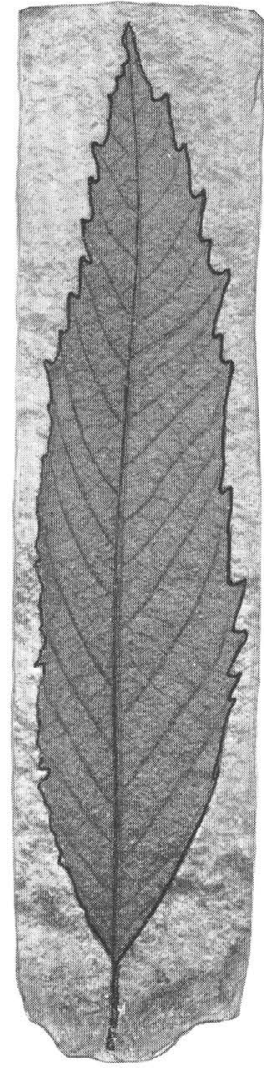

2

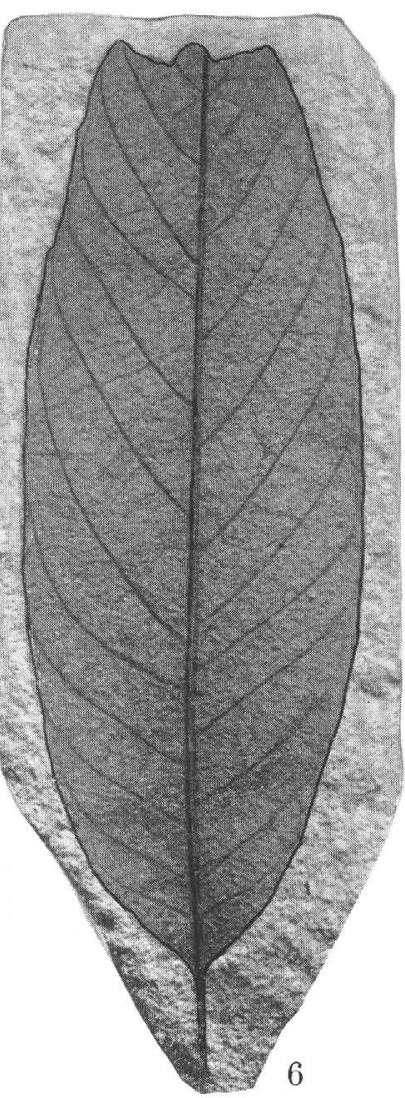

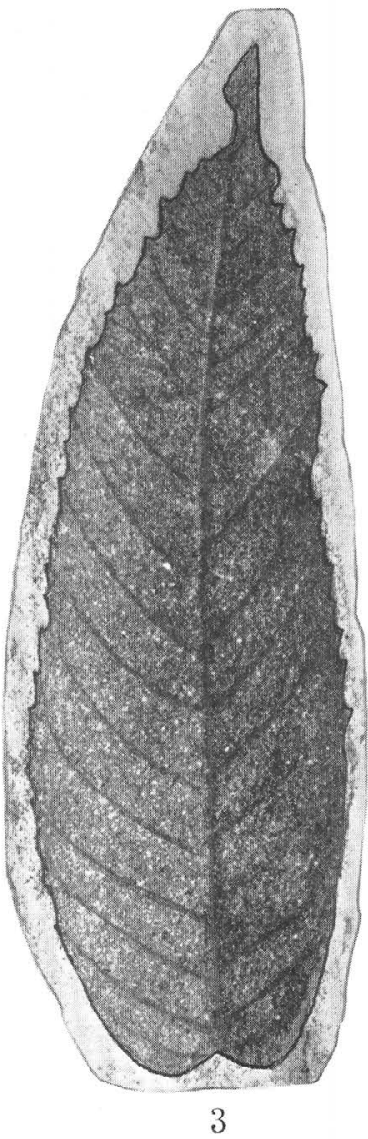
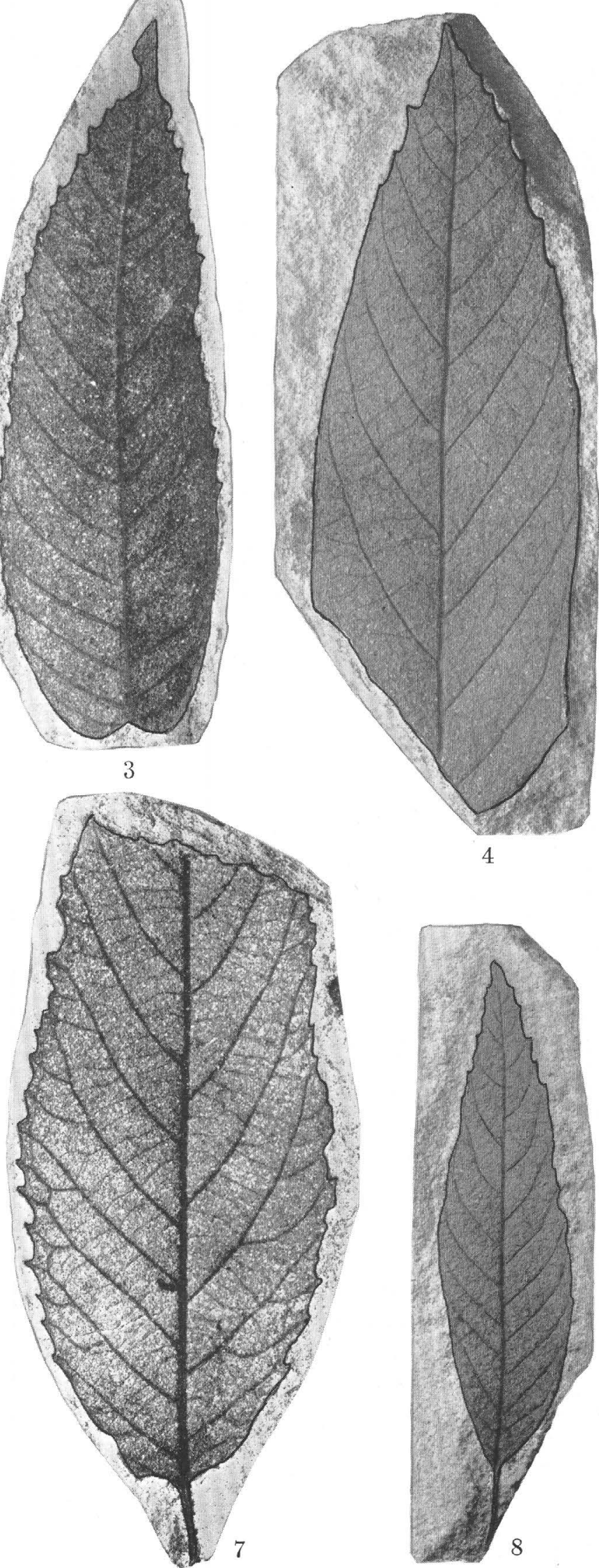

FOSSIL PLANTS FROM THE COLGATE MEMBER OF THE FOX HILLS SANDSTONE AND ADJACENT STRATA. 


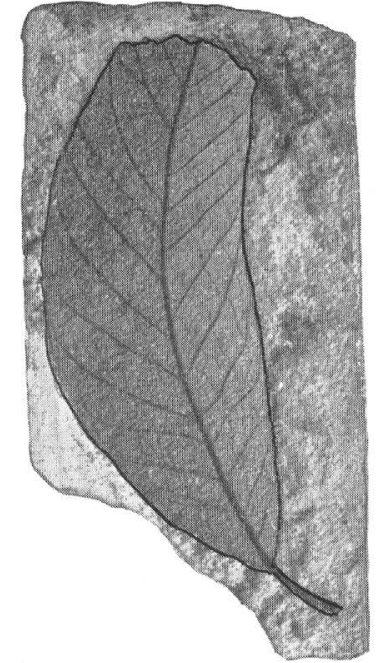

1

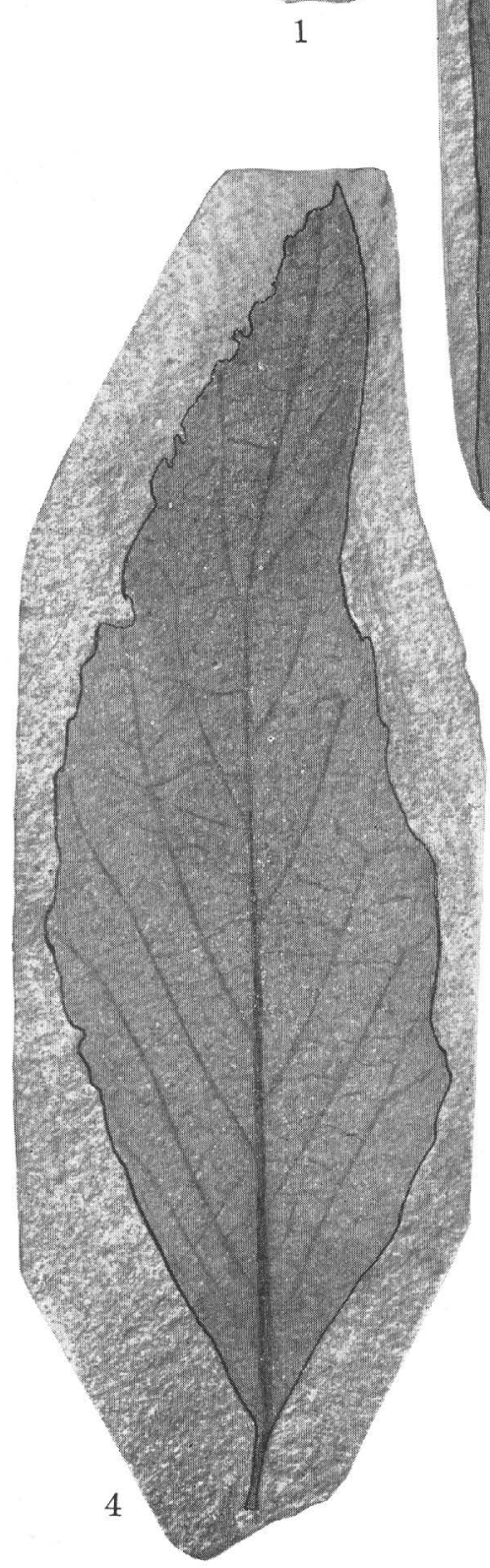

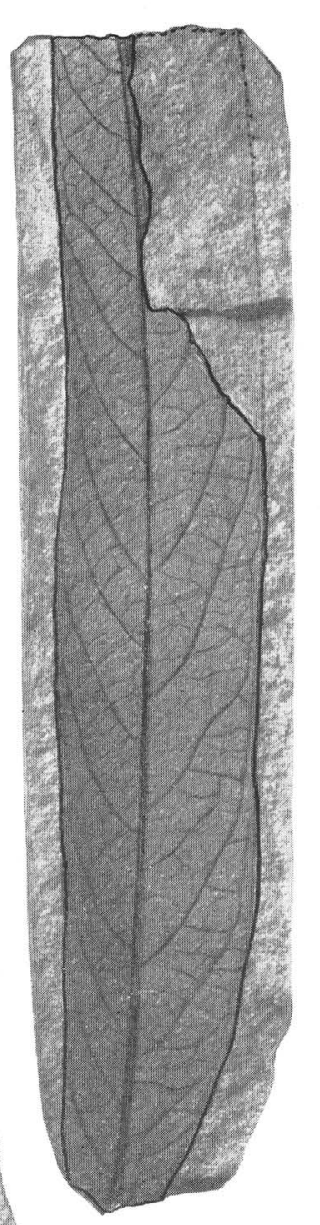

2

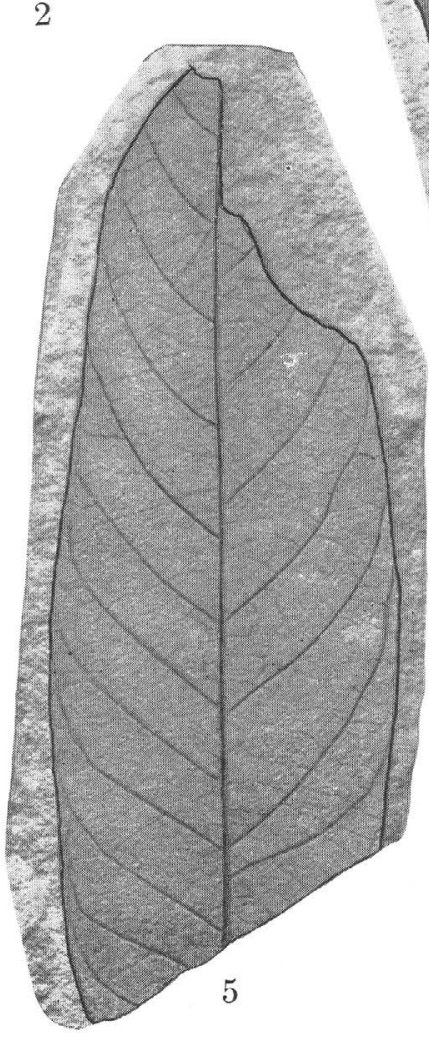

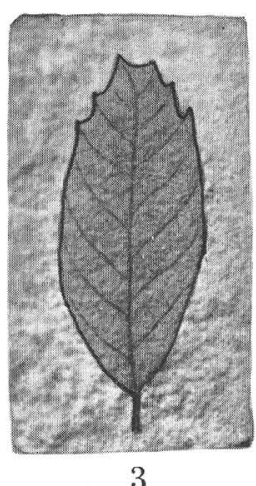
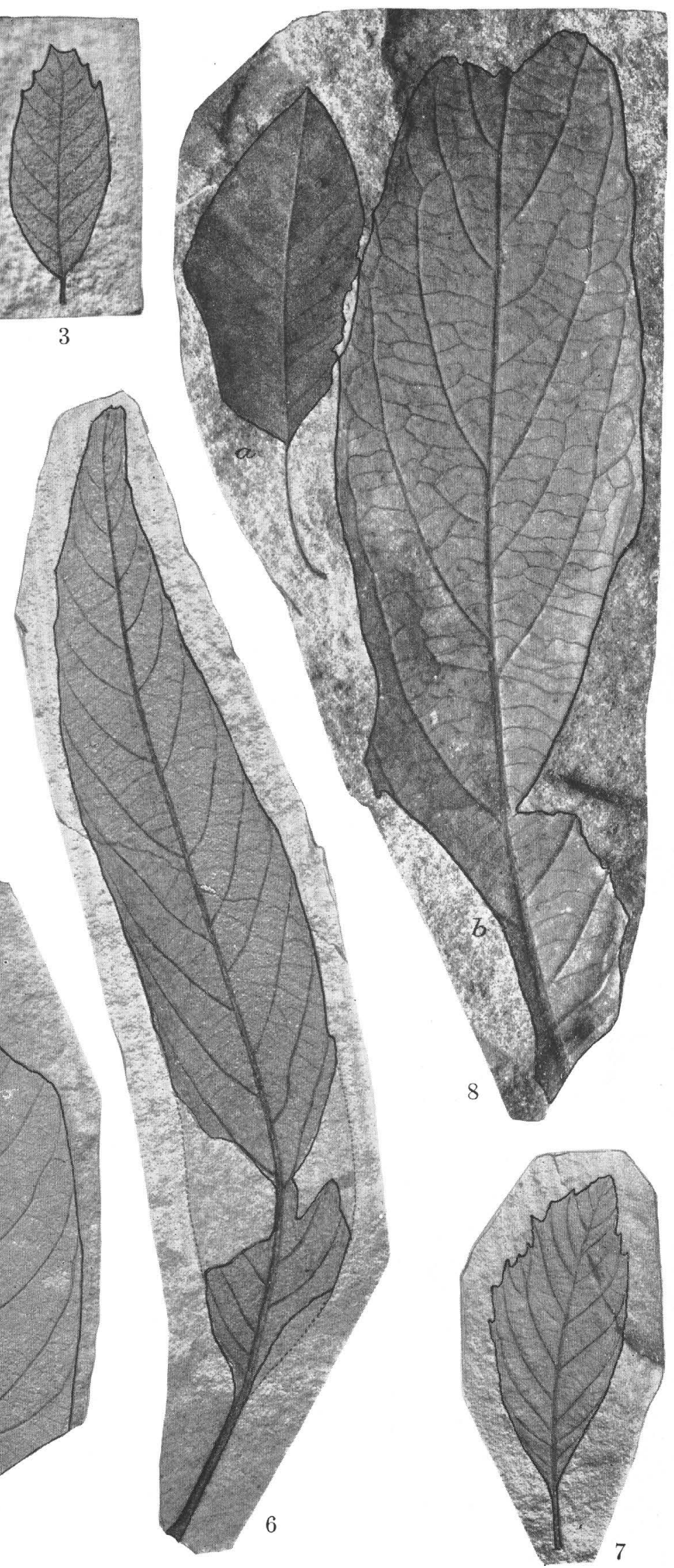

FOSSIL PLANTS FROM THE COLGATE MEMBER OF THE FOX HILlS SANDSTONE AND ADJACENT STRATA. 


\section{PLATE 51}

Figures 1-7, 8b. Dryophyllum subfalcatum Lesquereux. Colgate member, locality 4269 (figs. 1-7); Fox Hills sandstone, locality 5436 (fig. 8b)

8a. Phyllites sp. Fox Hills sandstone, locality $5436 \ldots$ 


\section{PLATE 52}

Figures 1-3. Dryophyllum subfalcatum Lesquereux. Hell Creek formation, locality $8197 \ldots$

4. Sassafras montana Brown, n. sp. Hell Creek formation, locality $8197 \ldots$

5, 6a. Paranymphaea hastata Brown, n. sp. Fox Hills sandstone, locality 5436_...

6b. Nilssonia gibbsii (Newberry) Hollick. Fox Hills sandstone, locality 5436 _ _ _

7. Liriodendron sp. Colgate member, locality $4269 \ldots$ 260 

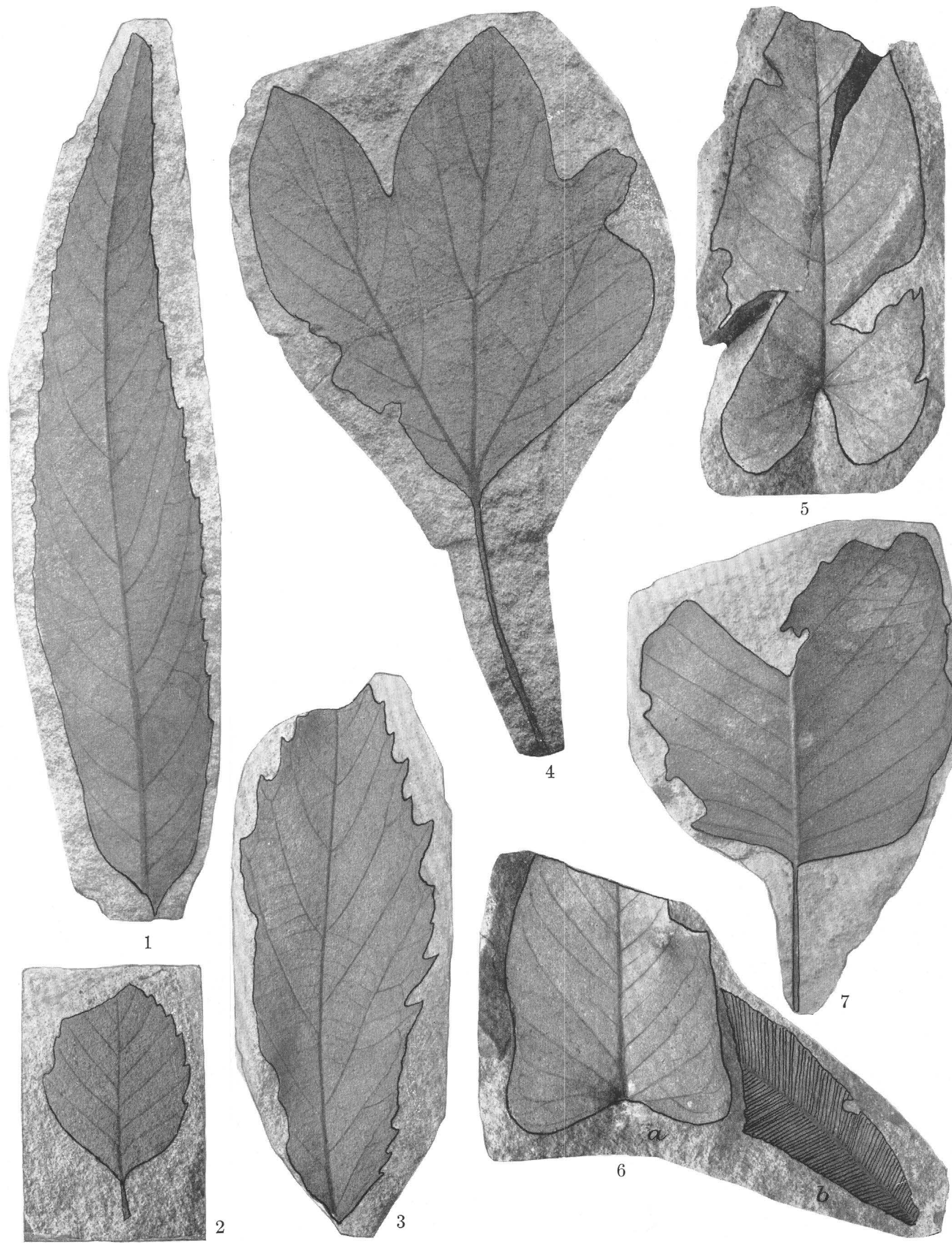

5
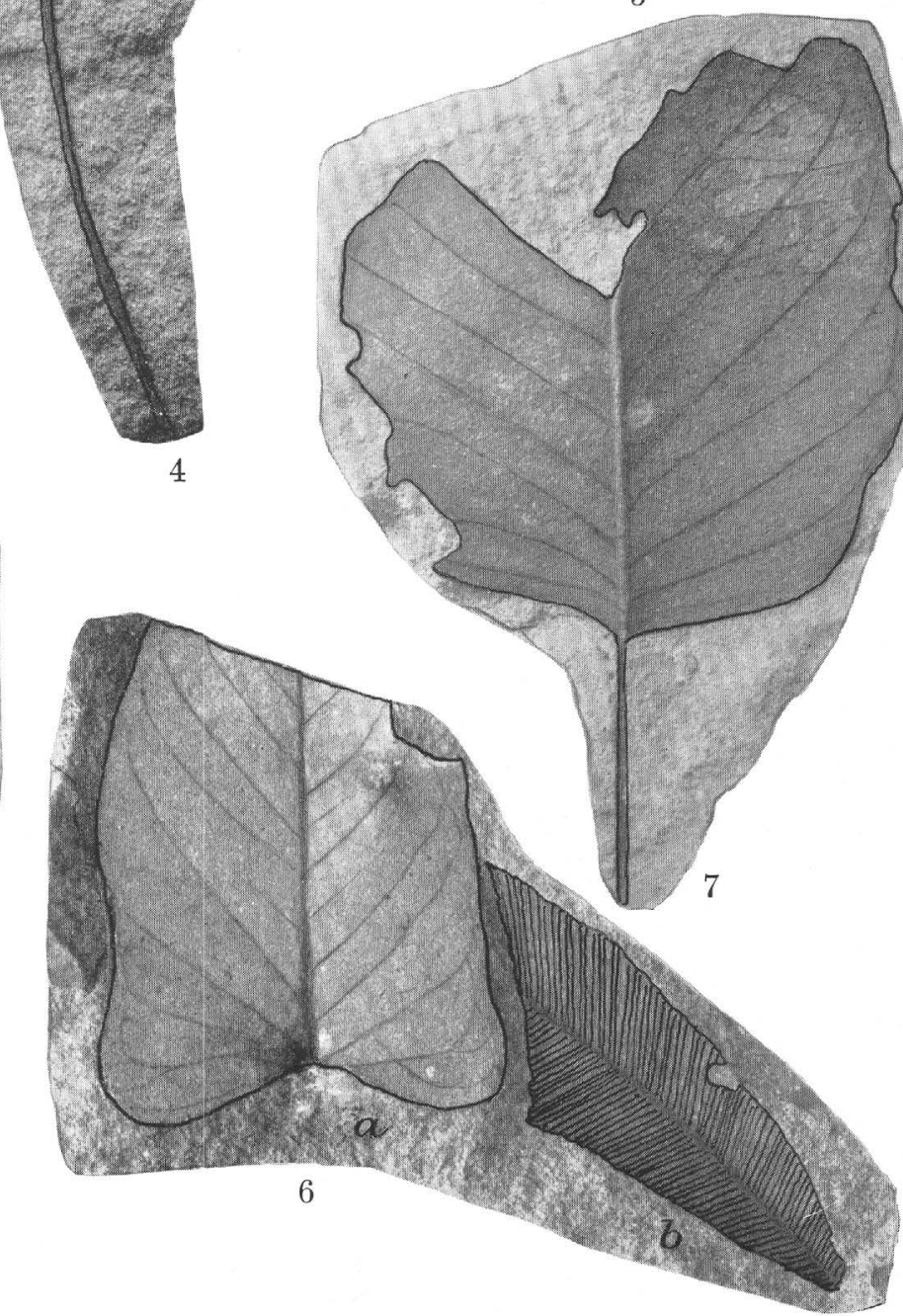

FOSSIL PLANTS FROM THE COLGATE MEMBER OF THE FOX HILLS SANDSTONE AND ADJACENT STRATA. 


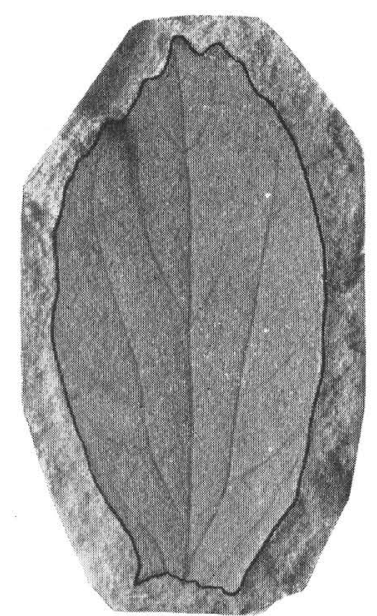

1

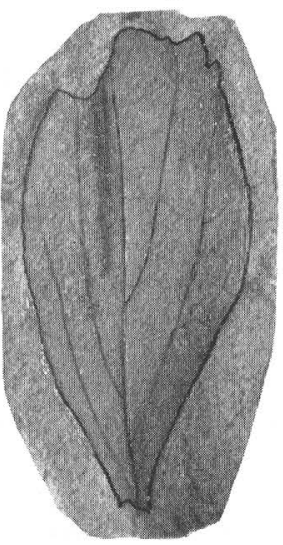

2

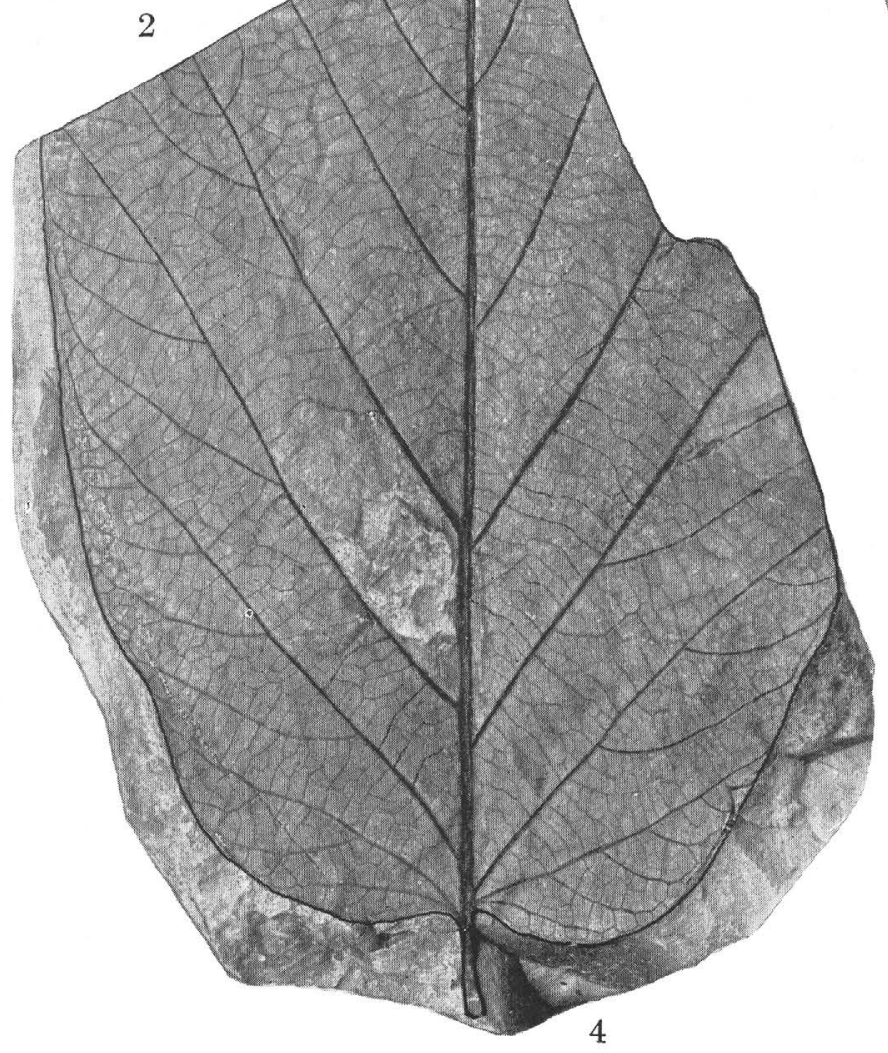

3
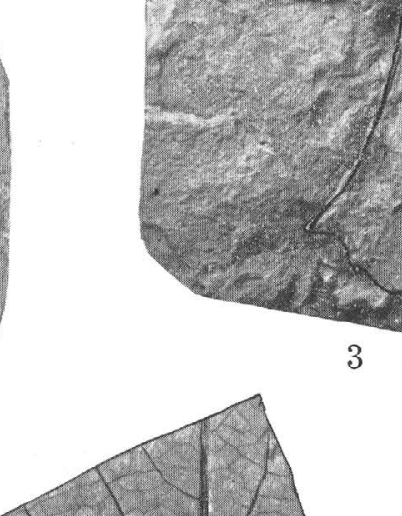

.
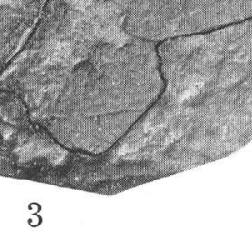
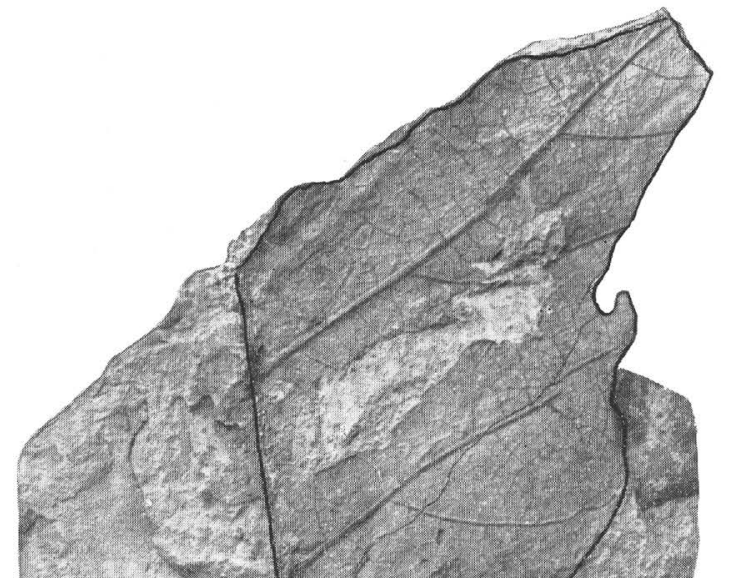


\section{PLATE 53}

Figures 1, 2. Cinnamomum affine Lesquereux. Colgate member, locality 4269

3-5. Ficus preartocarpoides Brown, n. sp. Hell Creek formation, locality 8242

6. Laurus lanceolata Knowlton. Colgate member, locality $4269 \ldots$ 


\section{PLATE 54}

Figure 1. Dryophyllum subfalcalum Lesquereux. Colgate member, locality 4269

2. Anona robusta Lesquereux. Hell Creek formation, locality $8197 \ldots$

3, 4. Magnolia nervosa (Knowlton) Brown, n. comb. Hell Creek formation, locality $8197 \ldots \ldots$

5. Magnolia lakesii Knowlton. Colgate member, locality $4269 \ldots$ 262 
GEOLOGICAL SURVEY

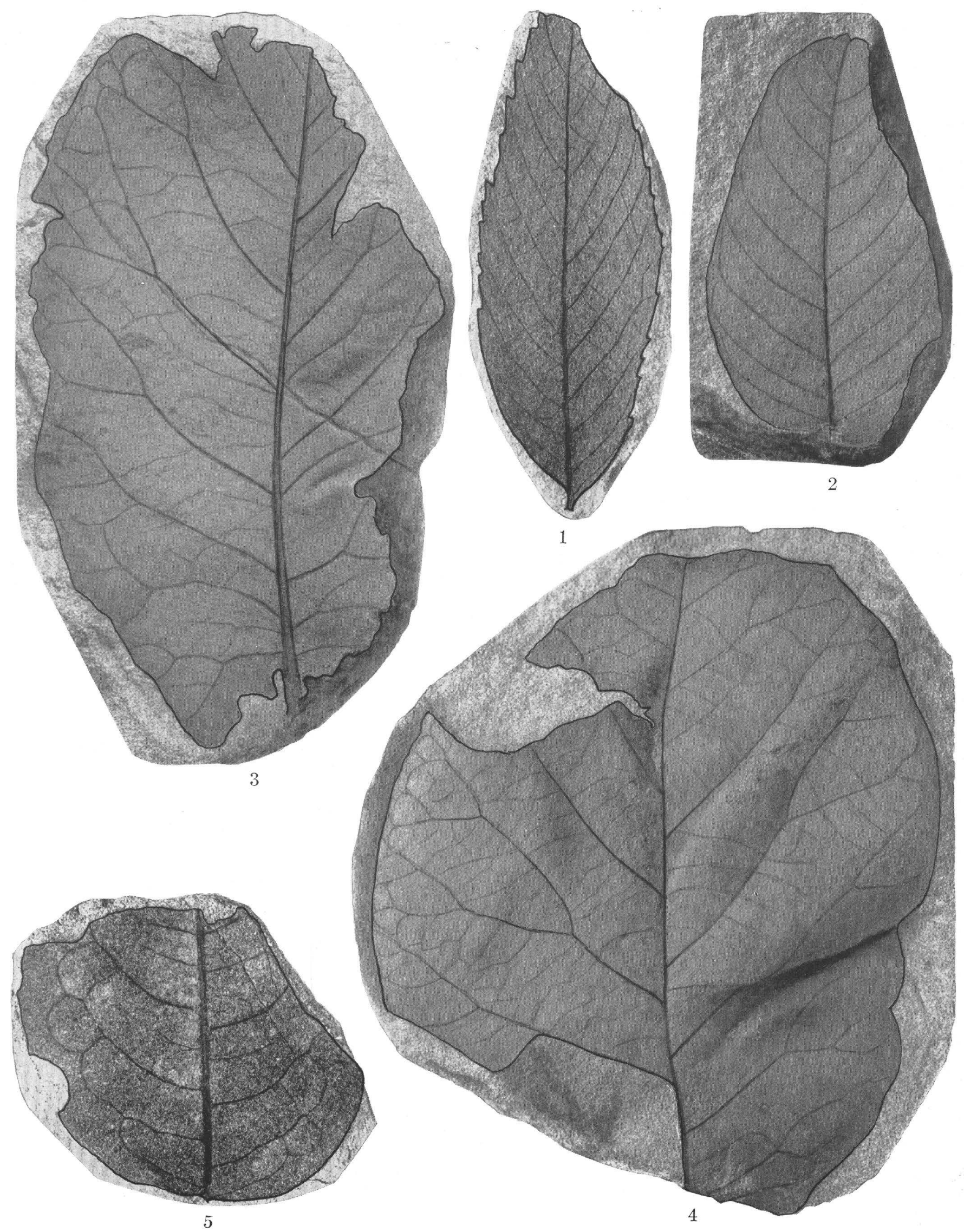

FOSSIL PLANTS FROM THE COLGATE MEMBER OF THE FOX HILLS SANDSTONE AND ADJACENT STRATA. 


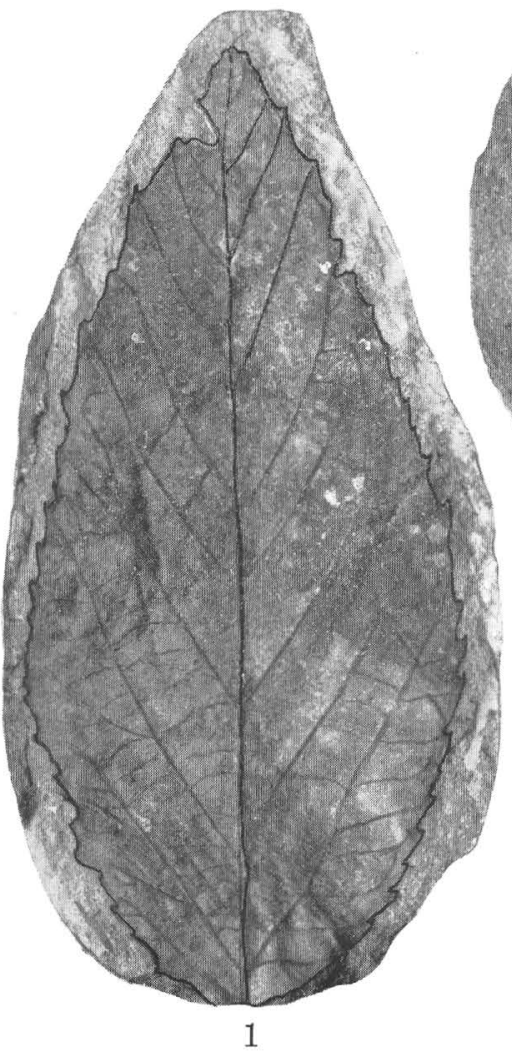

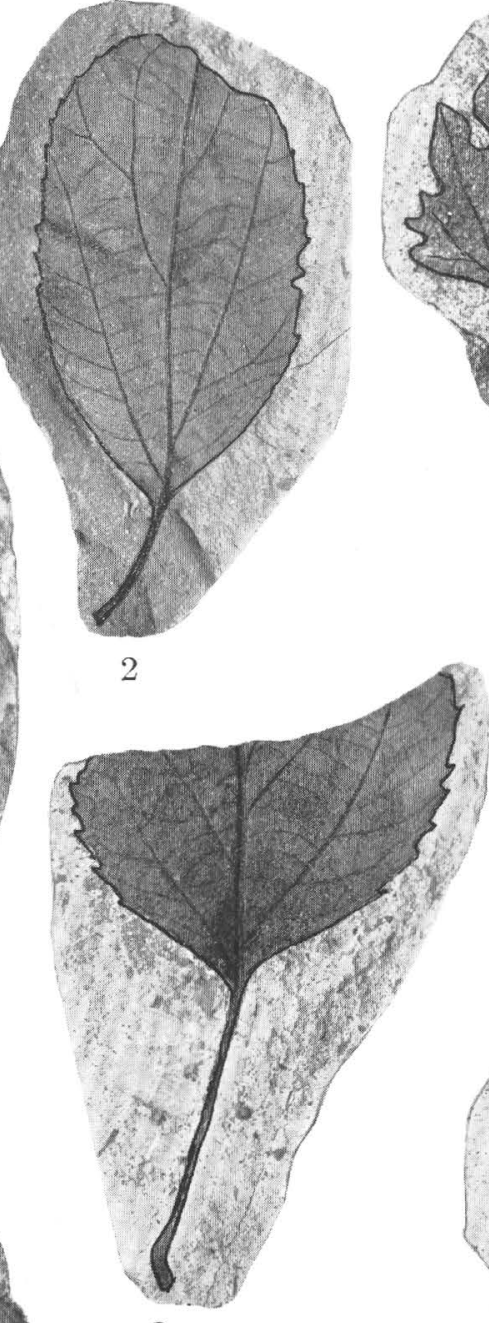

3

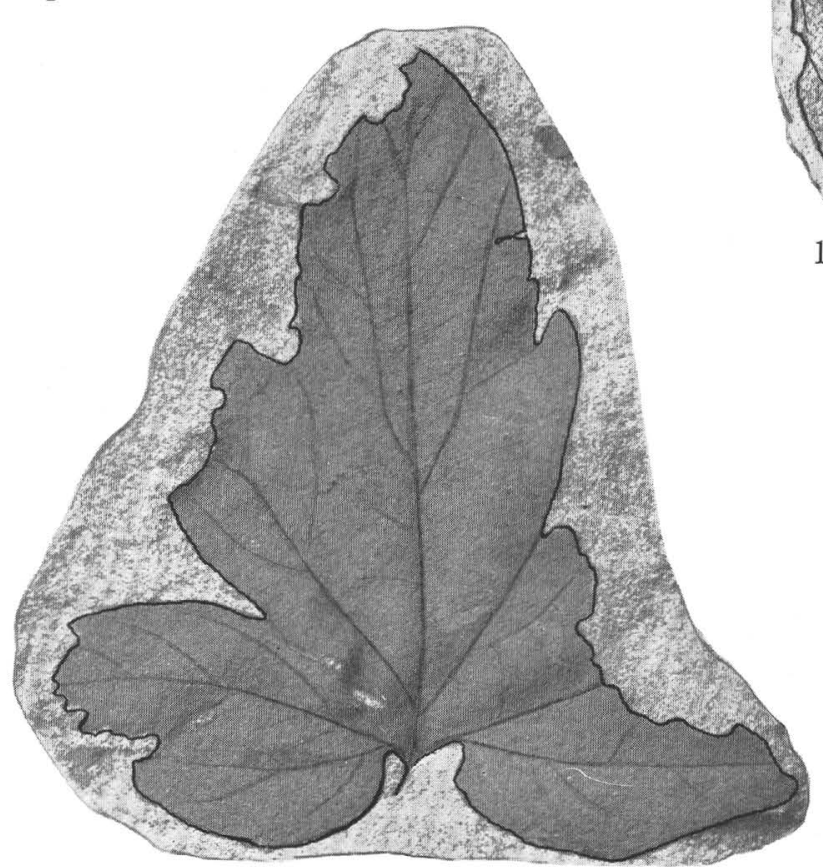

8

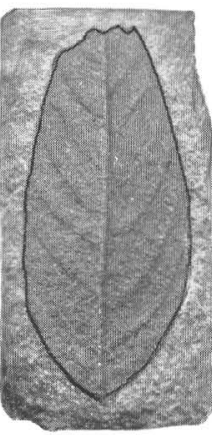

9

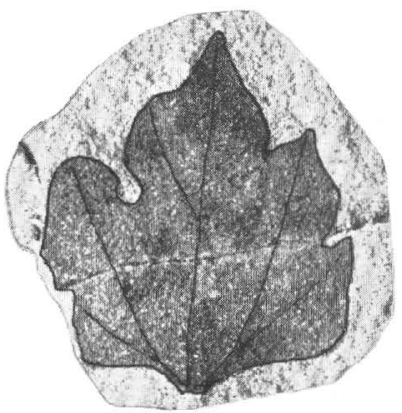

6

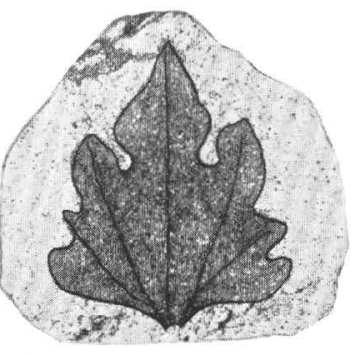

7

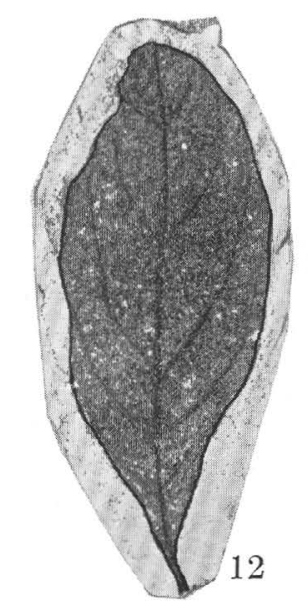

FOSSIL PLANTS FROM THE COLGATE MEMBER OF THE FOX HILlS SANDSTONE AND ADJACENT STRATA. 


\section{PLATE 55}

Figures 1-3, 4a. Grewiopsis saportana Lesquereux. Hell Creek formation, locality $8242 \ldots$

4b. Sassafras montana Brown, n. sp. Hell Creek formation, locality $8242 \ldots$

5-7. Cissites colgatensis Brown, n. sp. Colgate member, locality 4269

8. Cissites panduratus Knowlton. Hell Creek formation, locality $8197 \ldots$

9, 10. Sapindus cretaceus Brown, n. sp. Hell Creek formation, locality $8197 \ldots$

11. Cornus praeimpressa Knowlton. Colgate member, locality $4269 \ldots \ldots \ldots$

12. Diospyros berryana Knowlton. Colgate member, locality $4269 \ldots$ 
PLATE 56

Figures 1-5, 6b. Vitis stantoni (Knowlton) Brown, n. comb. Colgate member, locality 4269 (figs. 1, 2, 4, 5, 6b); Hell Creek formation, locality 8197 (fig. 3)

6a. Pistia corrugata Lesquereux. Colgate member, locality $4269 \ldots$ 

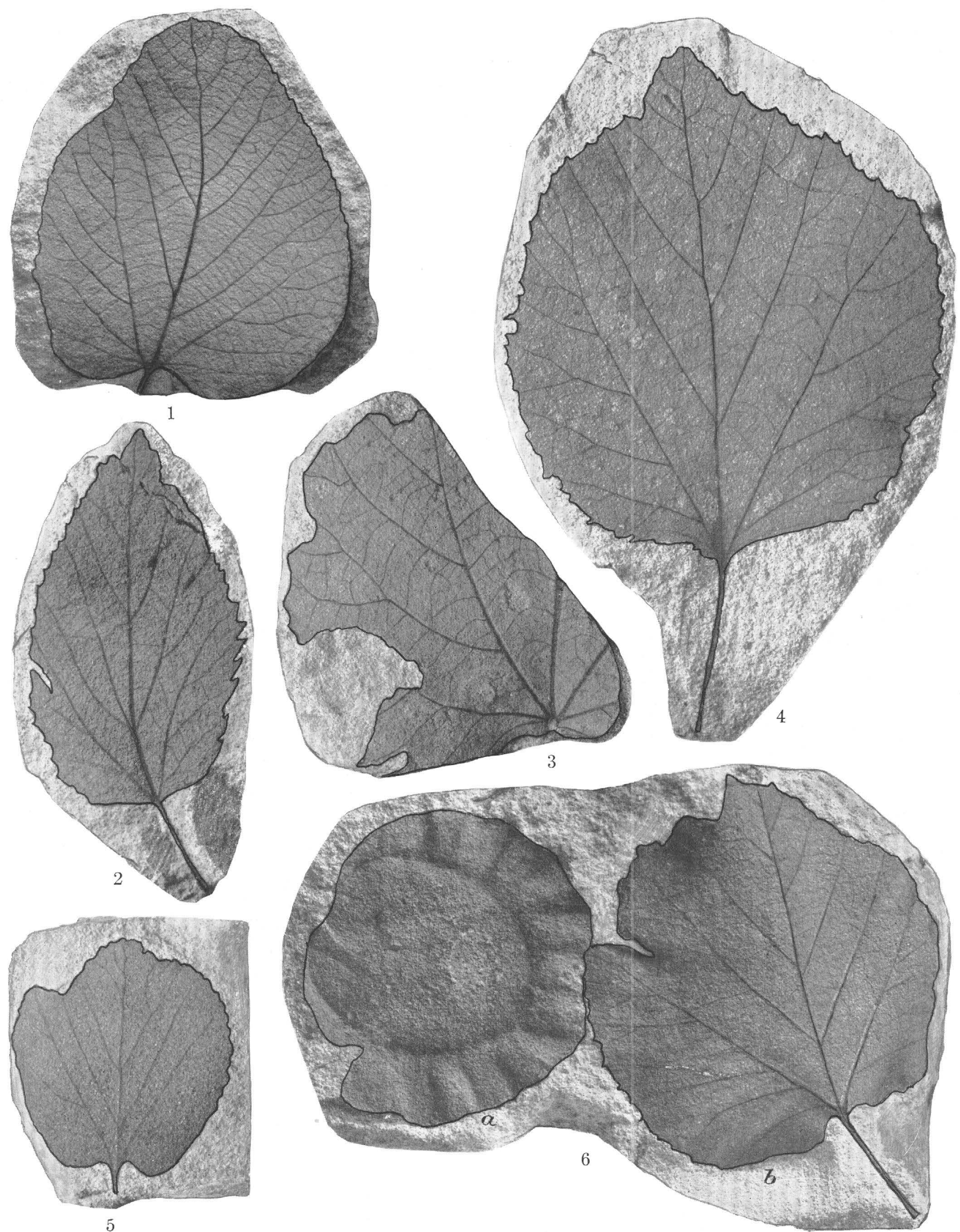

FOSSIL PLANTS FROM THE COLGATE MEMBER OF THE FOX HLLS SANDSTONE AND ADJACENT STRATA. 


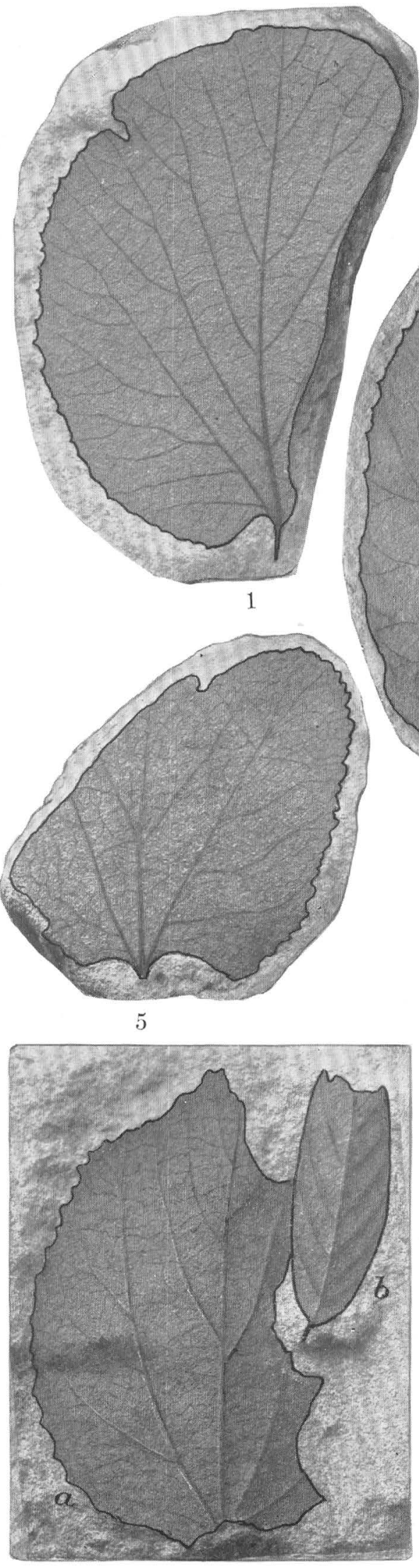

7
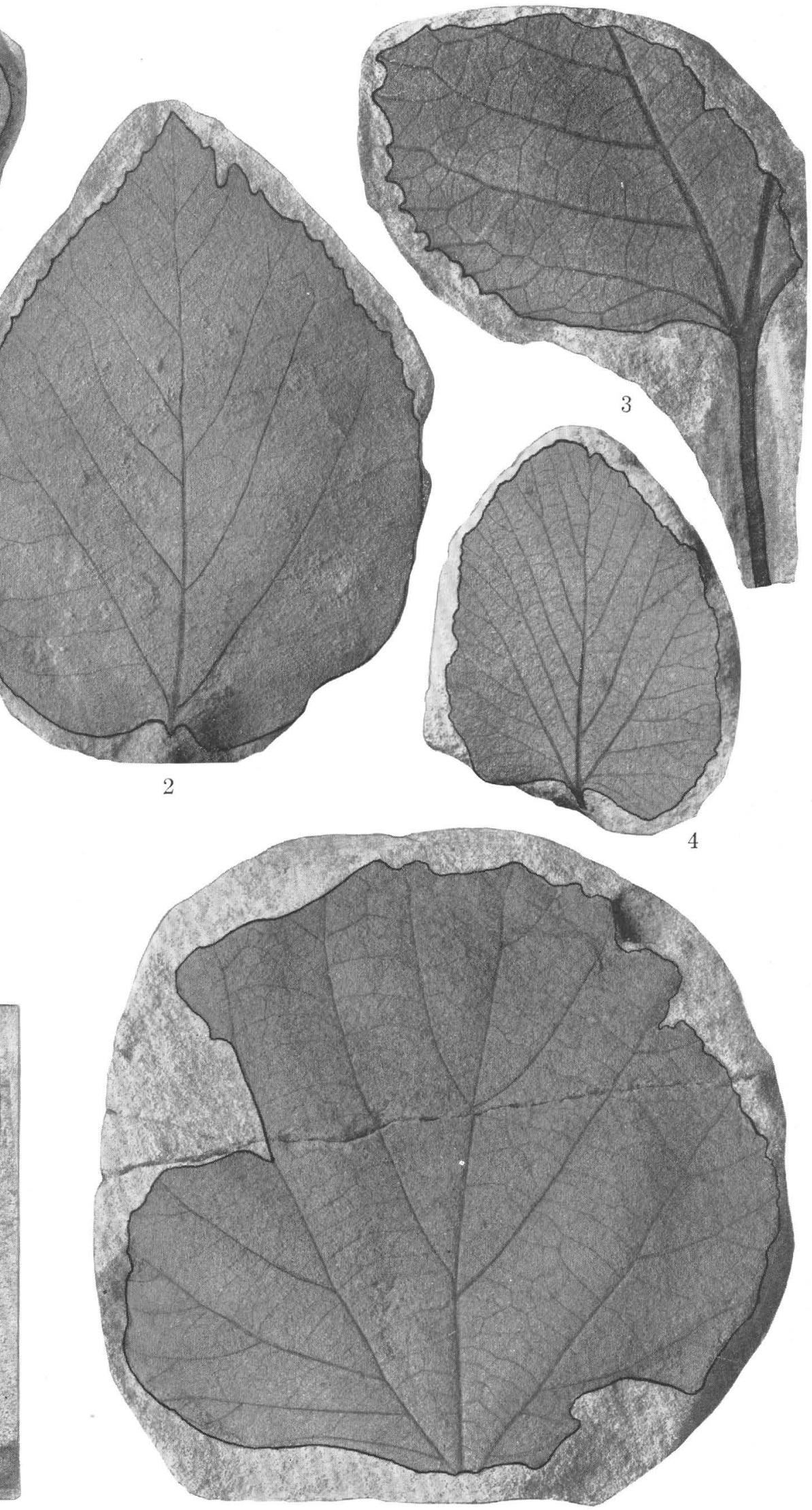

6

FOSSIL PLANTS FROM THE COLGATE MEMBER OF THE FOX HILLS SANDSTONE AND ADJACENT STRATA. 


\section{PLATE 57}

Page

Figures 1-6, 7a. Vitis stantoni (Knowlton) Brown, n. comb. Colgate member, locality 4269 (figs. 1-5); Hell Creek formation, locality 8197 (figs. 6, 7a) _...........

7b. Sapindus cretaceus Brown, n. sp. Hell Creek formation, locality 8197 
Figures 1-4. Vitis stantoni (Knowlton) Brown, n. comb. Fox Hills sandstone, locality 4143 (figs. 3, 4); Hell Creek formation, locality 8197 (figs. 1, 2) 266 

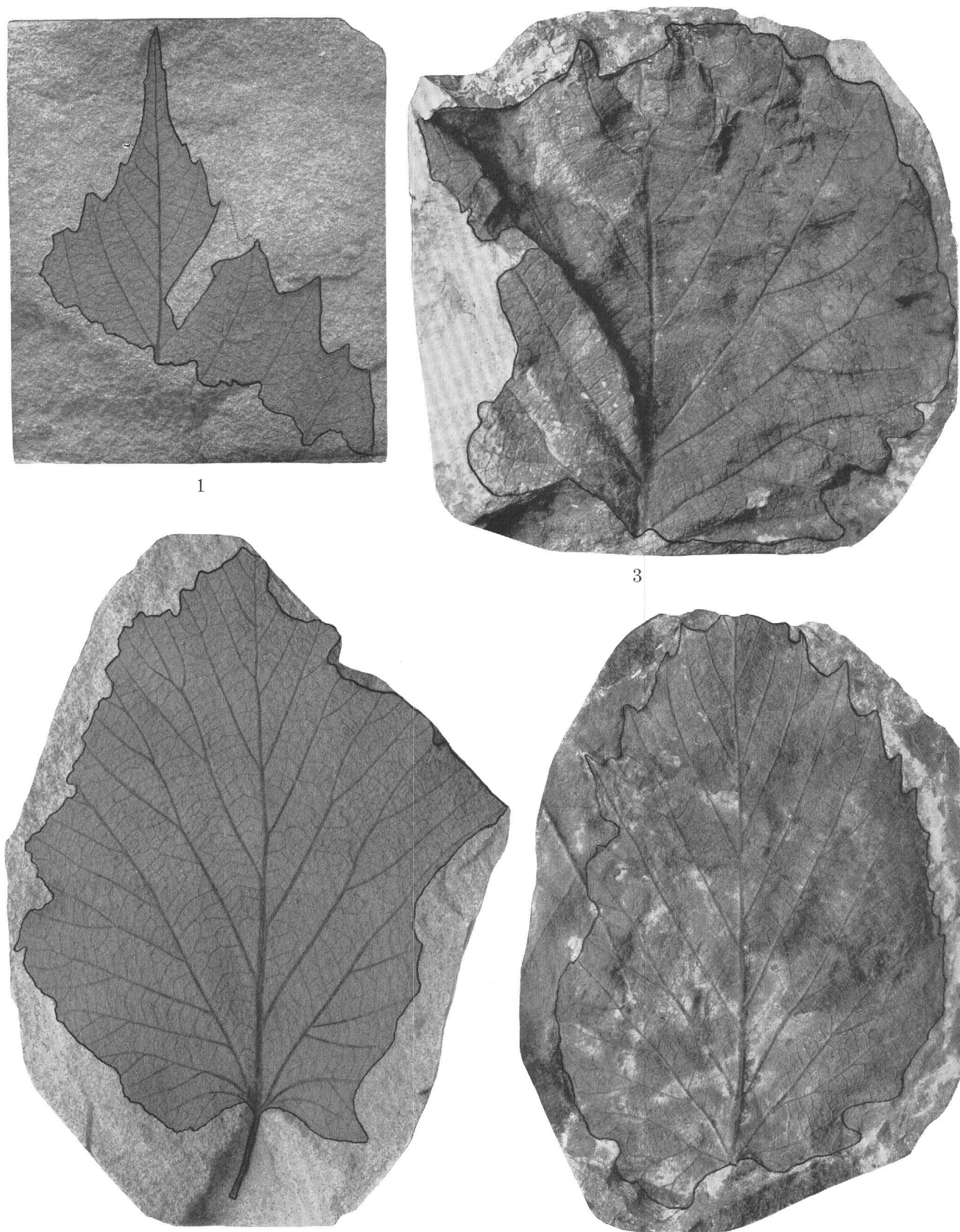

3

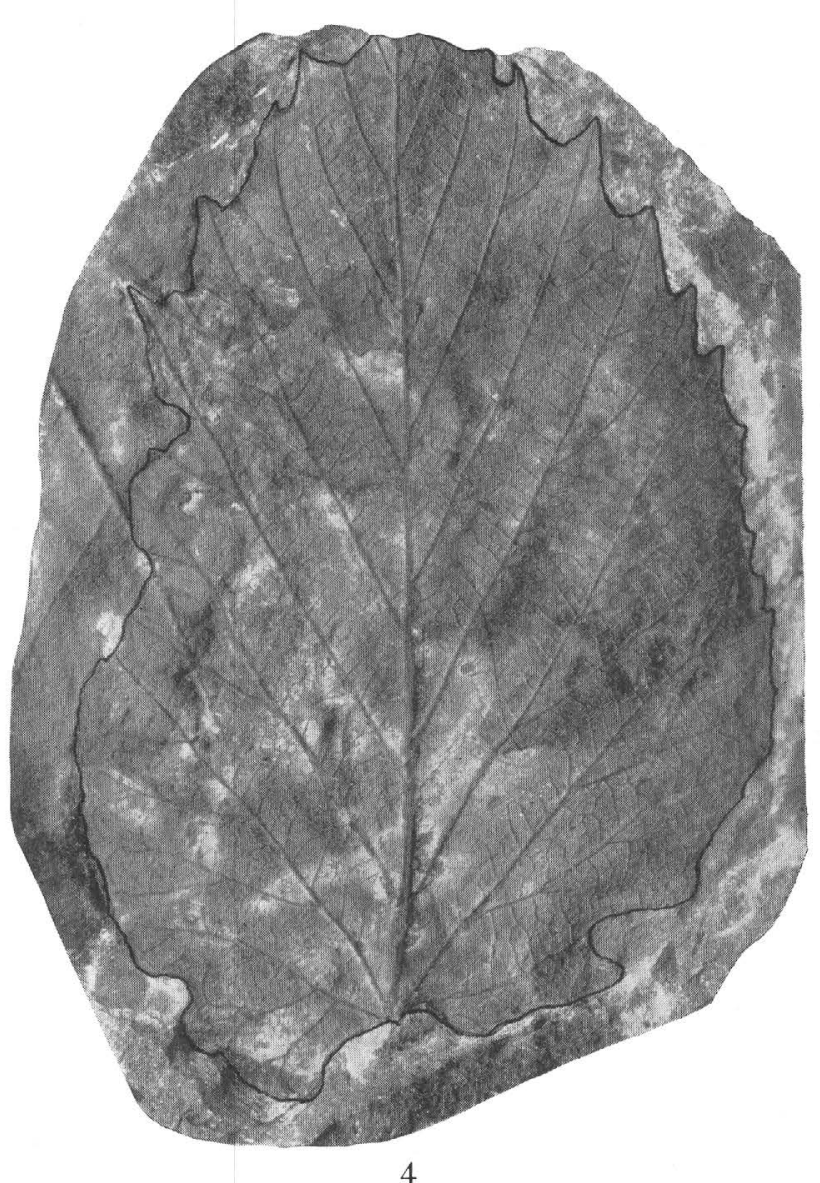

4

FOSSIL PLANTS FROM THE COLGATE MEMBER OF THE FOX HILLS SANDSTONE AND ADJACENT STRATA. 


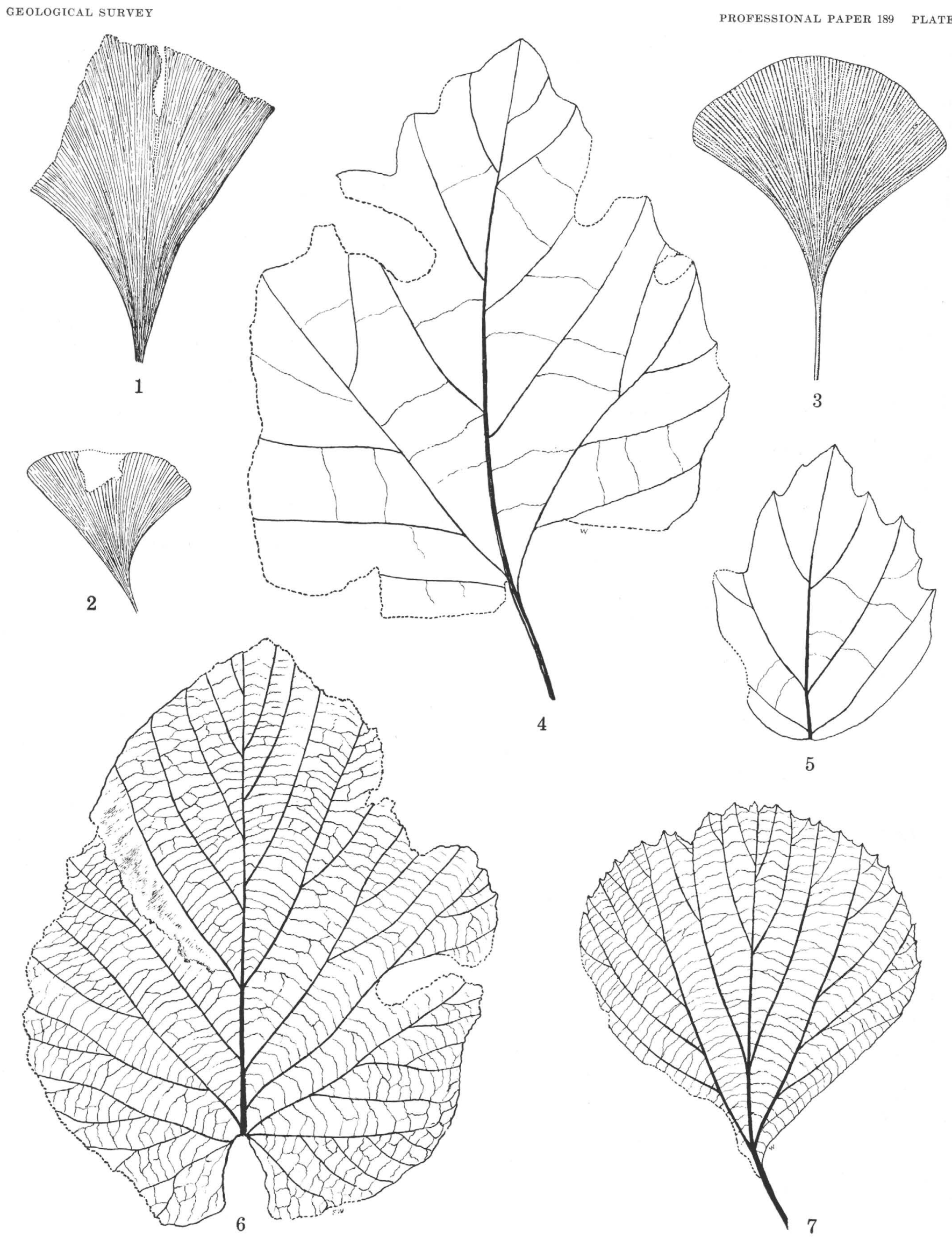

FOSSIL PLANTS FROM THE COLGATE MEMBER OF THE FOX HILLS SANDSTONE AND ADJACENT STRATA, 


\section{PLATE 59}

[Drawings by Miss Frances Wieser]

FIgURes 1-3. Ginkgo laramiensis Ward. Hell Creek formation, locality 4144

4, 5. Platanus sp. Fox Hills sandstone, locality $5436 \ldots$

6. Vitis stantoni (Knowlton) Brown, n. comb. Fox Hills sandstone, locality $4143 \ldots \ldots$

7. Viburnum marginatum Lesquereux. Hell Creek formation, locality 8518 
PLATE 60

Figures 1-4. Dombeyopsis colgatensis Brown, n. sp. Colgate member, locality $4269 \ldots 252$

5-7. Phyllites sp. Colgate member, locality 4269

8. Phyllites sp. Hell Creek formation, locality $8197 \ldots$ 


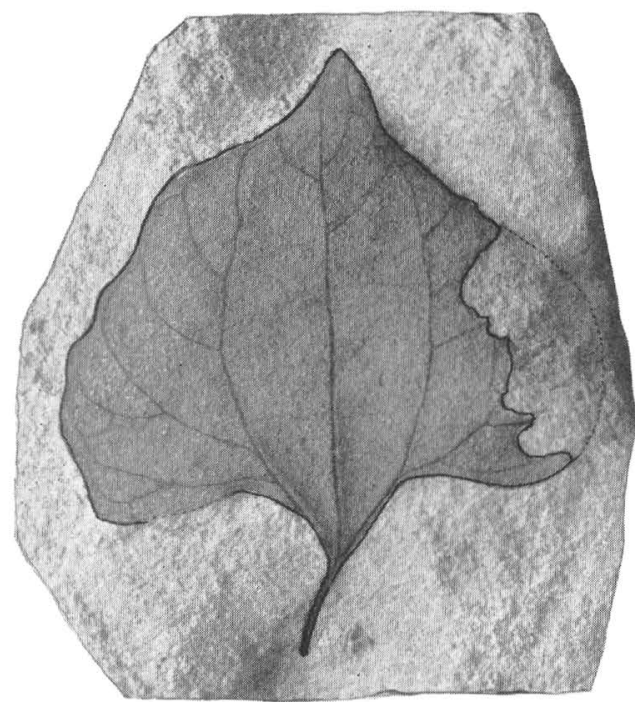

1
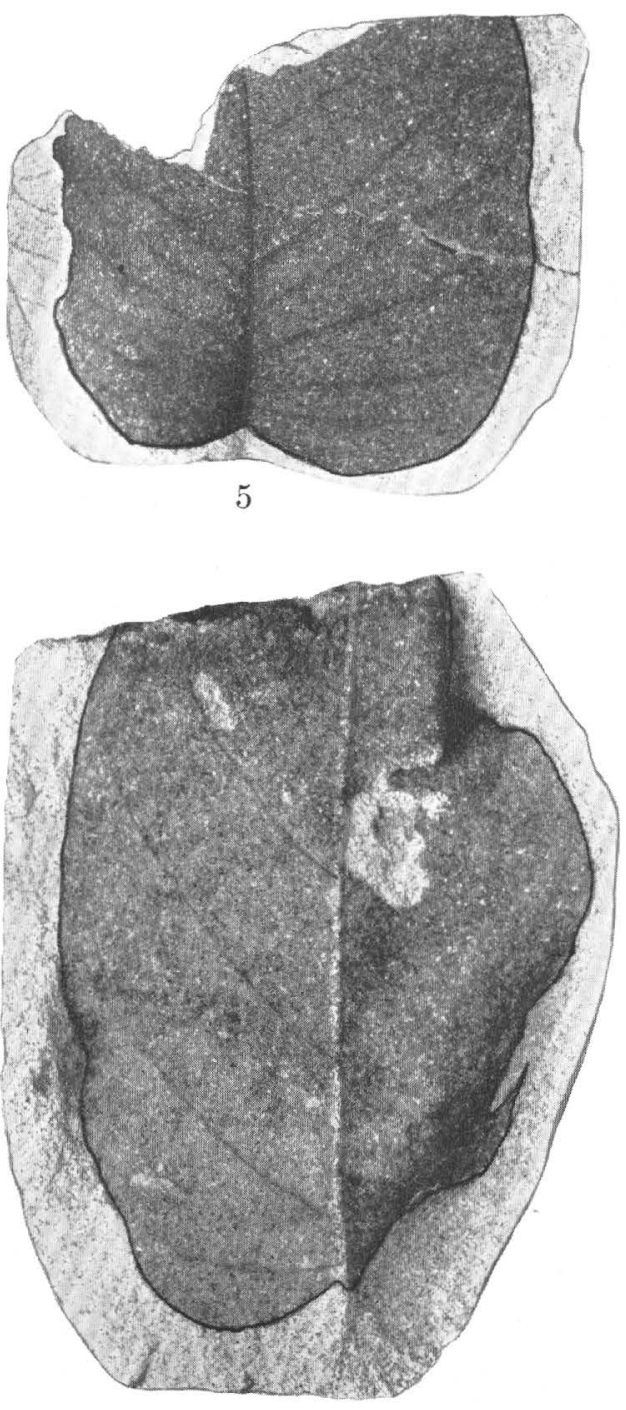

6
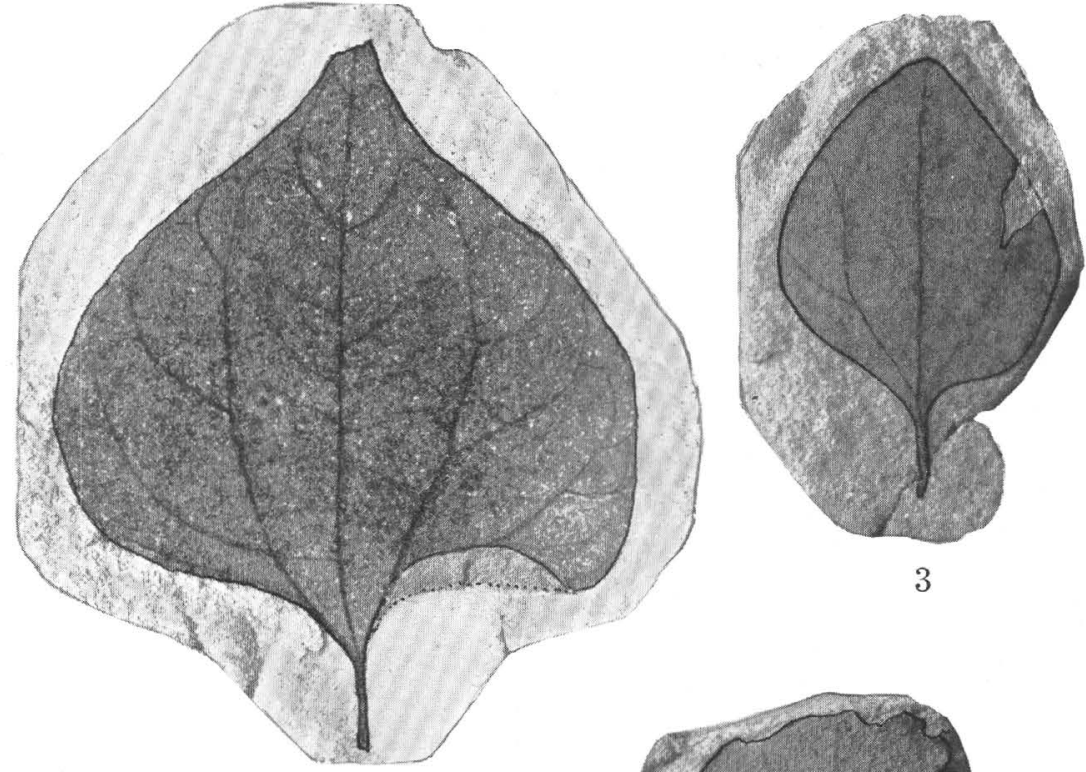

3

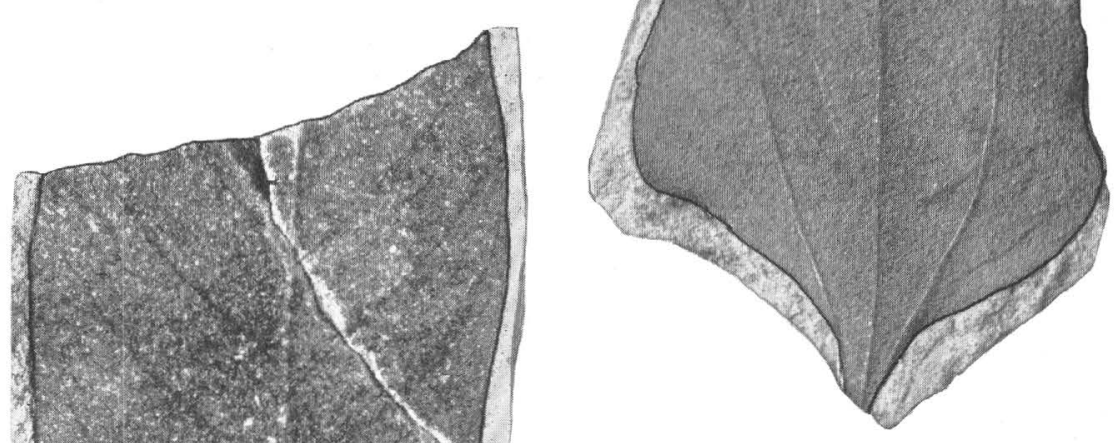

4

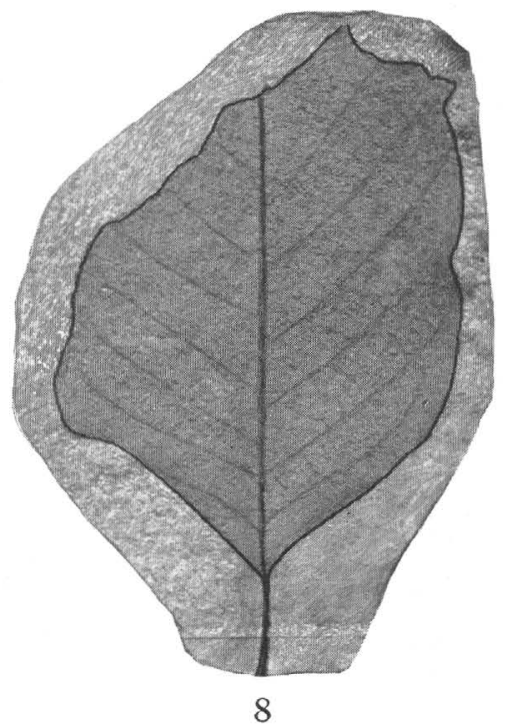

8

FOSSIL PLANTS FROM THE COLGATE MEMBER OF THE FOX HILLS SANDSTONE AND ADJACENT STRATA. 

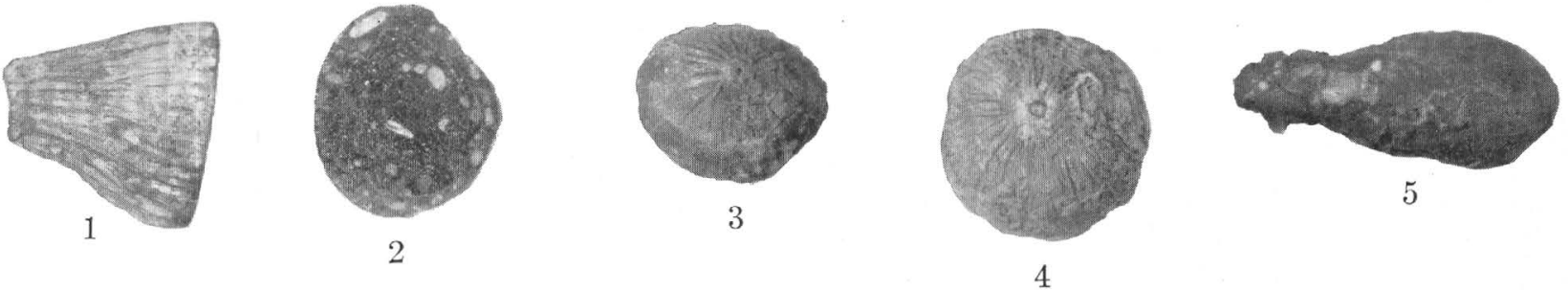

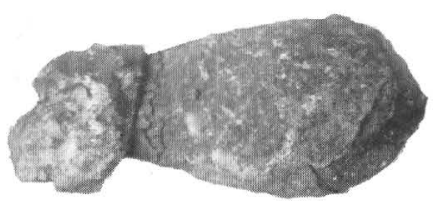

6

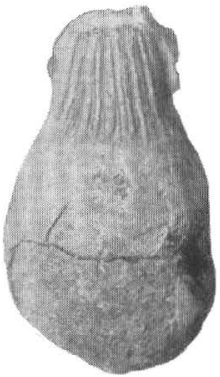

10
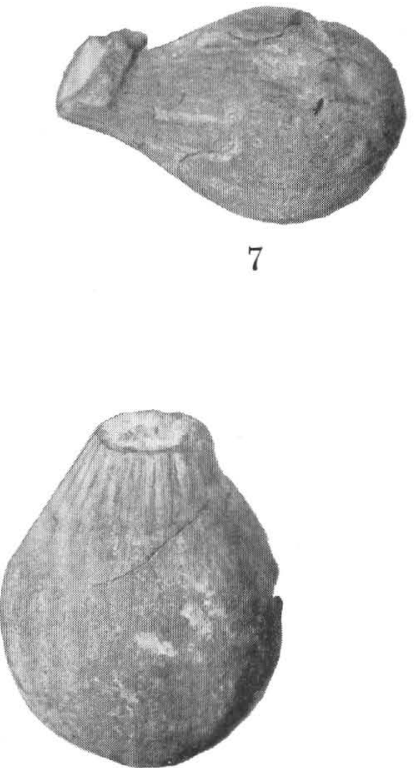

11
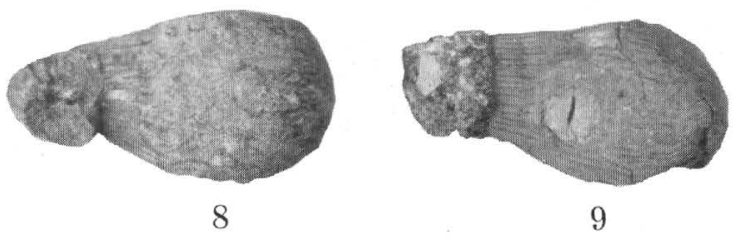

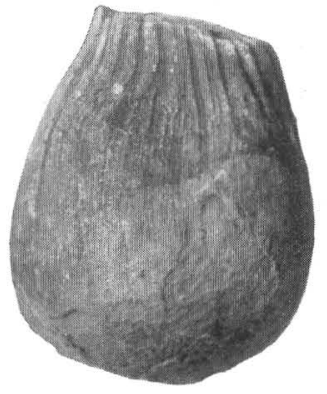

12

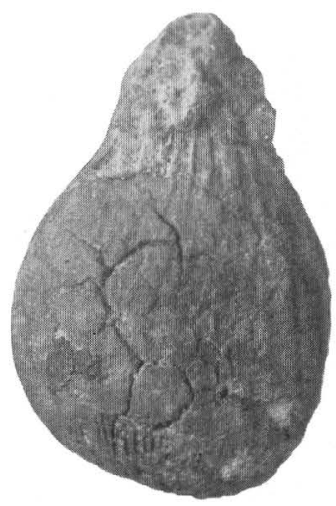

13

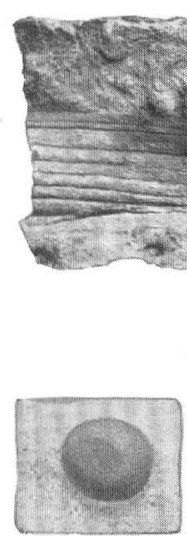

15

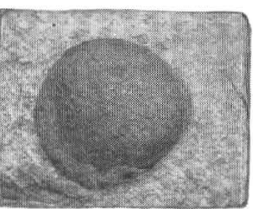

16
14

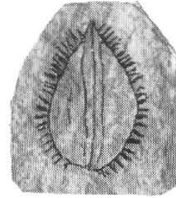

17

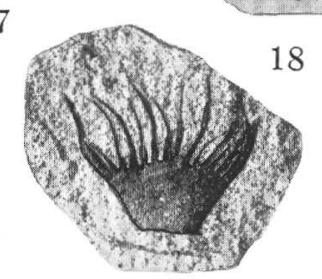

20

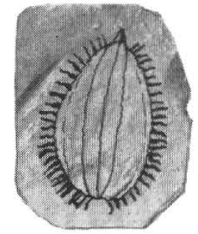

18

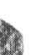

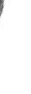

0

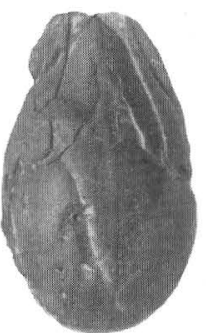

22

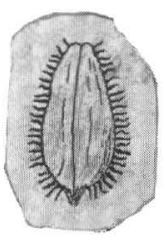

19

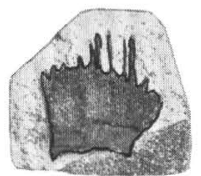

21

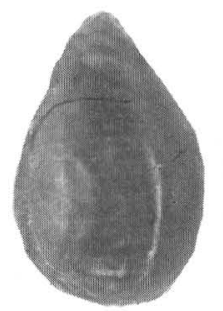

23
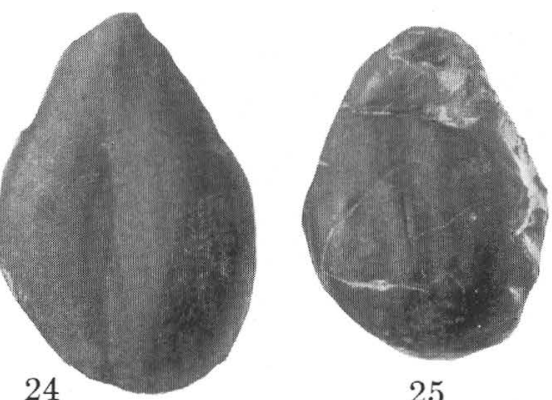

25

FOSSIL PLANTS FROM THE COLGATE MEMBER OF THE FOX HILLS SANDSTONE AND ADJACENT STRATA. 


\section{PLATE 61}

Figures 1-13. Ficus ceratops Knowlton. Hell Creek formation, locality $8154 \ldots$

14. Probably the impression of a stem of Equisetum. Hell Creek formation, locality $8154 \ldots \ldots$

15, 16. Carpolithus sp. Colgate member, locality 4269 (fig. 15); Hell Creek formation, locality 8197 (fig. 16) _._. 253

17-19. Carpolithus hirsutus Newberry. Hell Creek formation, locality 8531

20, 21. Calycites sp. Colgate member, locality 4269

22-25. Carpclithus sp. Hell Creek formation, locality $8260 \ldots$ 
Figures 1-7. Halymenites major Lesquereux. Fox Hills sandstone, Marmarth, N. Dak. (figs. 1, 6, 7); Ripley formation, Enon, Ala. (fig. 4); Nanjemoy formation, Popes Creek, Md., wharf (figs. 2, 3, 5). Figures 6 and 7 are radia] and transverse sections, respectively, of figure 1, showing the phosphatic pellets of the core, and the outer crust. Figure 5 is a transverse section of figure 2, showing similar structures 


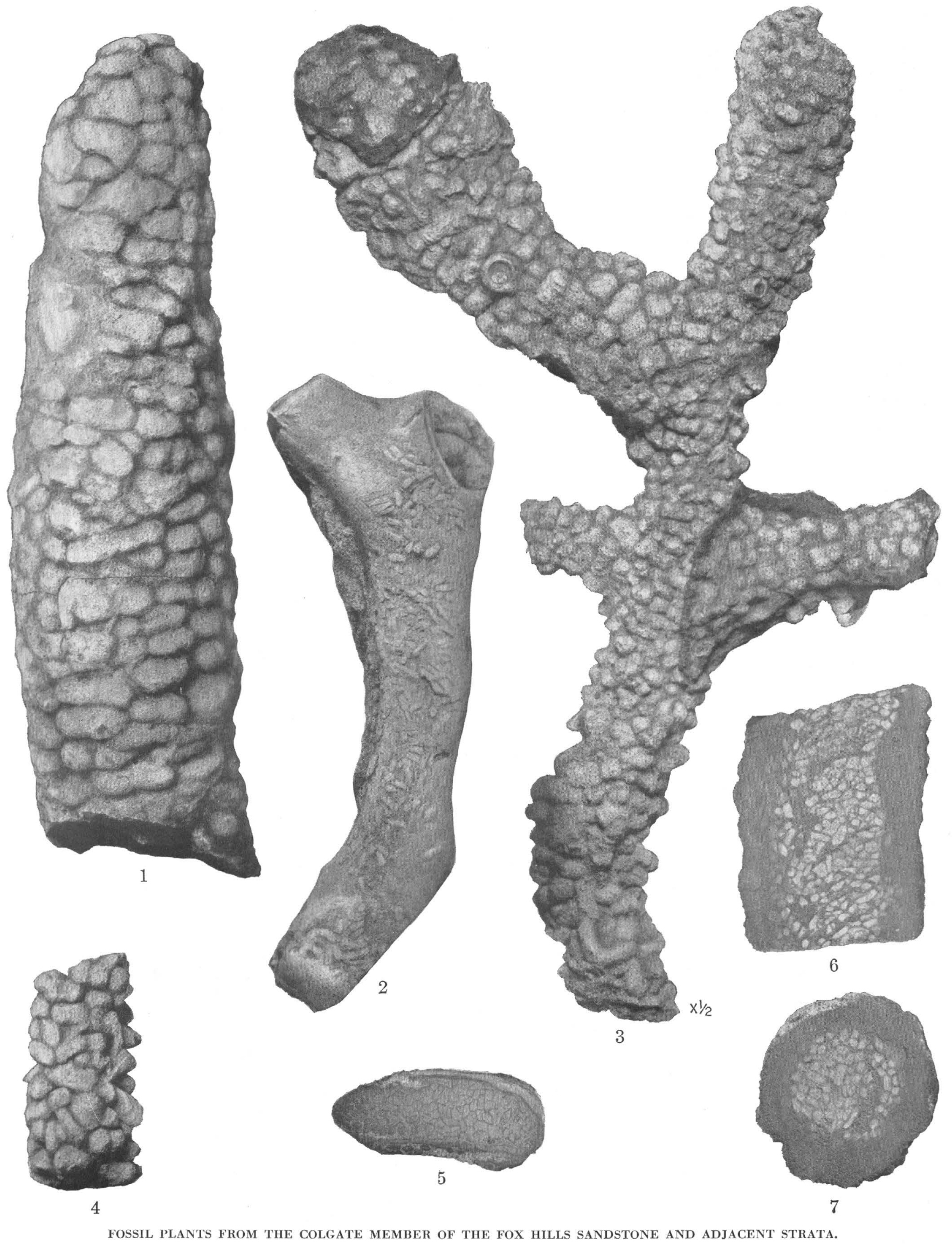




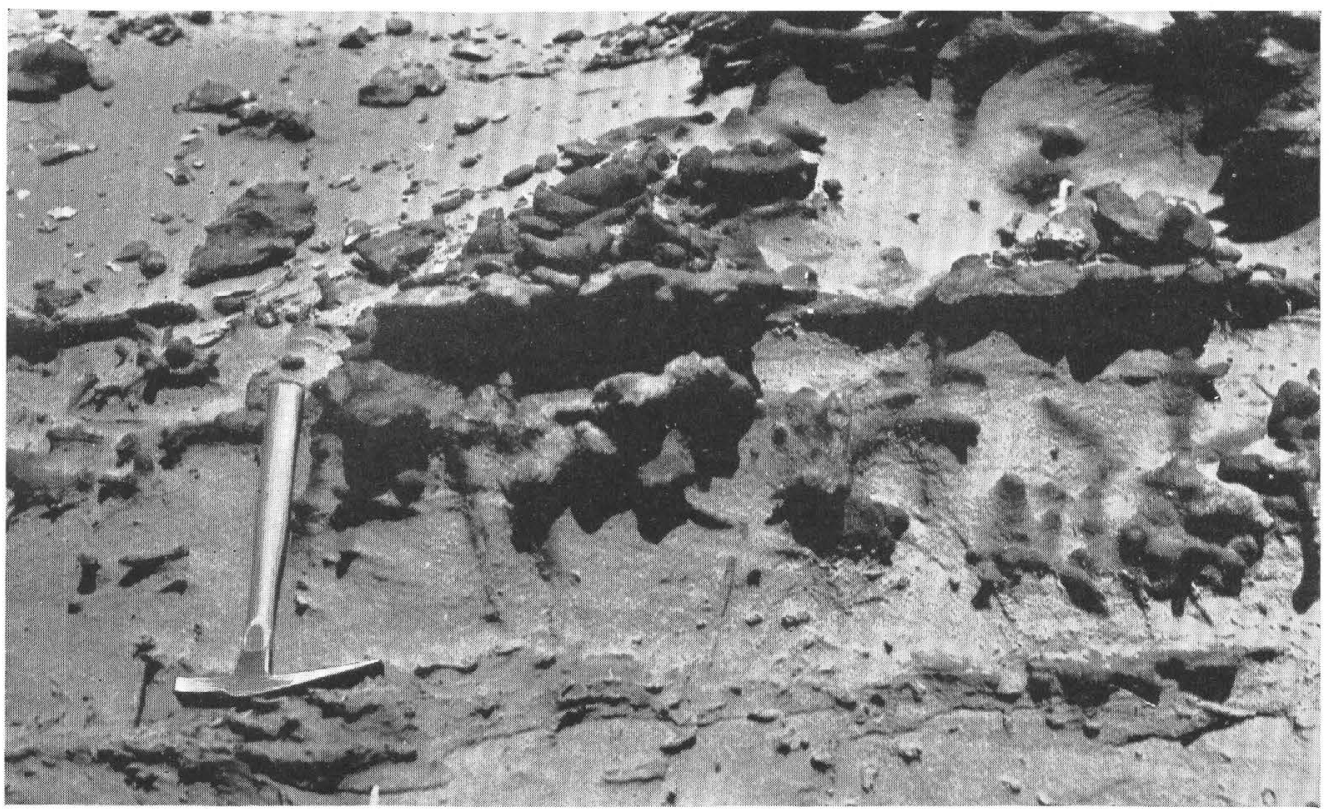

1

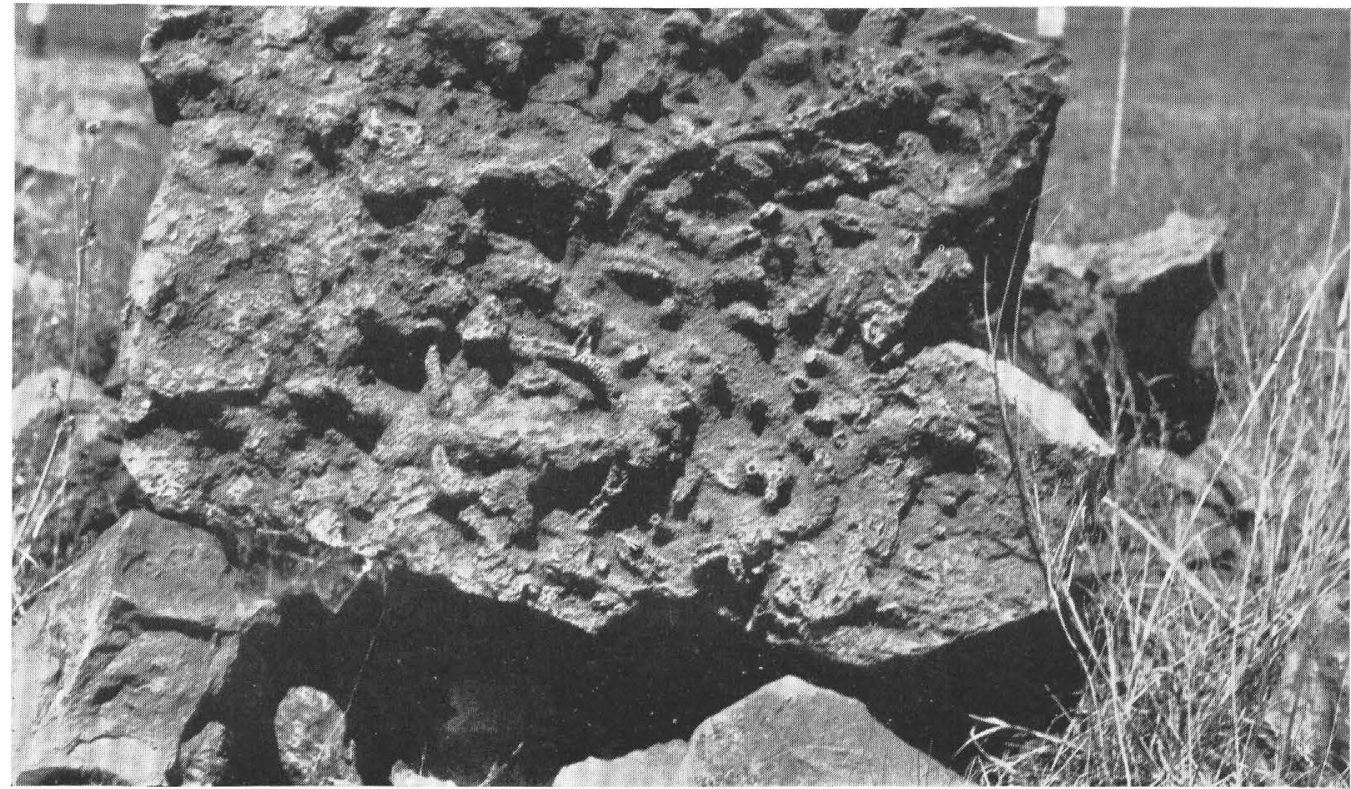

2

FosSIL PLANTS FROM THE COLGATE MEMBER OF THE FOX HILlS SANDSTONE AND ADJACENT STRATA. 


\section{PLATE 63}

Figdre 1. Showing habit of Halymenites major Lesquereux. Fox Hills sandstone, 3 miles west of Fort Yates, along road to Selfridge, N. Dak

2. Under side of block of Fox Hills sandstone showing Halymenites major disposed along bedding plane. Same locality 



\section{INDEX}

A

Abies.

Abstract...

239

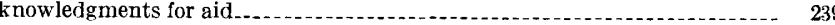

adiantoides, Ginkgo ........ 245, 246, 247

affine, Cinnamomum . . ................... 242, 243, 250, pl. 53

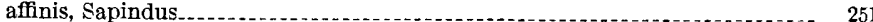

Aleurites eocenica - . . .

amblyrhyncha, Populus

americana, Ottelia

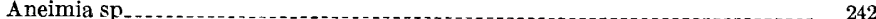

Anona robusta.

A nonaceae...

antiqua, Brasenia

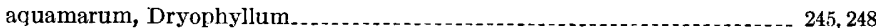

Araceae

areticum, Equisetum

arenacea, Ficus _. _

Aristolochia . ... 250, 253 coloradensis . .

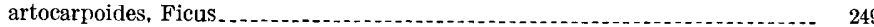

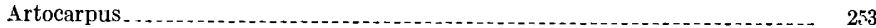

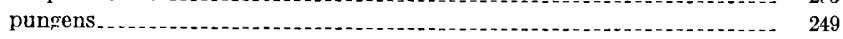

Asplenium tenellum.

B

berryana, Diospyros.

$242,243,252$, pl. 55

Bignoniaceae

biloba, Ginkgo

Braseni

rasenia....

antiqua.

Calycites $\mathrm{sp}$

$\mathrm{C}$

253, pl. 6

Caprifoliaceae

Carpolithus hirsutus 252 spinosus.

$243,244,245,253$, pI. 61

$\mathrm{sp}$

Costalia stantoni

Celastrus

Cephalotaxus coloradensis

243, 244, 245, 248-249, pl. 61

Cinnamomum....... 247 affine

lanceolatum......................... 250

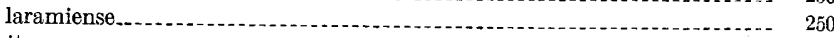

Cissites...

colgatensis.

formosus

panduratus....... 242

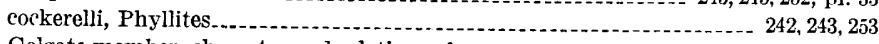

Colgate member, character and relations of correlation of ................... 240 previous collections from

colyatensis, Cissites.

Dombeyopsis........................ 60

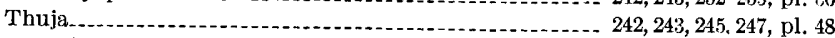

coloradensis, Aristolochia.

Cephalotaxus

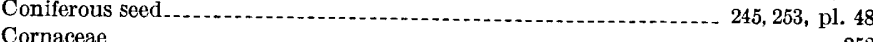

Cornaceae

corrugata, Pistia

$242,243,245,248$, pls. 49,56

(250

crenulata, Ginkgo . . .
cretacea, Thuja

Williamsonia

245,247 cretaceum, Sassafras

cretaceus, Sapindus............ 243, 245, 251-252, pls. 55, 57

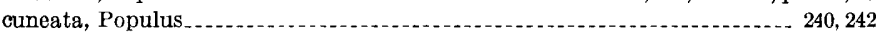

Cupressaceae.

Cycadaceae

dakotana, Vitis.

akotensis, Sequoia._..................................... 243, 244, 245, 247, pl. 48

awsoni, Ginkgo . . .

Nelumbo........ 242, 243, 248, 250, pl. 48

Quercus ............... 249

digitata, Ginkgo

Diospyros berryana...................................... 242, 243, 252, pl. 55

Dombeyopsis_............. 253 colgatensis..... 242, 243, 252-253, pl. 60 obtusa-...

Dryophyllum. ............. 244

aquamarum . .

bruneri $\ldots \ldots \ldots \ldots \ldots \ldots . . \ldots 24,248$

falcatum _. 245,248 subfalcatum

$\mathrm{E}$

Ebenaceae

eocenica, Aleurites. 251

Grewiopsis

Equisetum . . . arcticum sp

F

Fagaceae

falcatum, Dryophyllum . . .

ficifolia, Grewiopsis

Ficus............... 246, 253

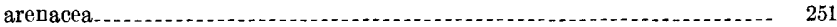

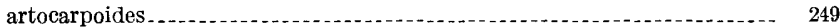

ceratops $. . .-243,244,245,248-219$, pl. 61 preartocarpoides........................ 243, 245, 249, pl. 53

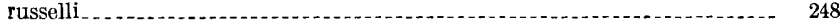

speciosissima. . . .

uncata

formosus, Cissites

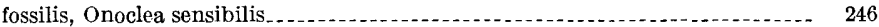

Fox Hills sandstone, fossil plant localities in . . _. . previous collections from relations of .

section of (-

summary of flora from

Fraxinus leei

G

gibbsii, Nilssonia _... _... Taeniopteris _

Ginkgo

adiantoides $\ldots \ldots \ldots \ldots$

biloba.

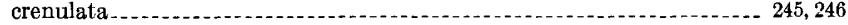

dawsoni .

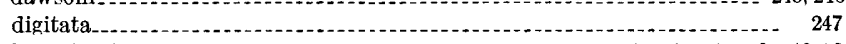

laramiensis................. 242, 243, 245, 246-247, pls. 48,59

minor _............. 245, 246, 247

pseudadiantoides major............................... 245, 246

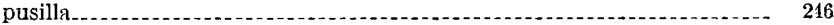

reniformis. . . . .

sp $\ldots$

Ginkgoaceae............ 246-247

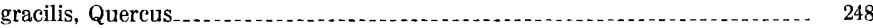

grandifoliolus, Sapindus. 
Grewiopsis

eocenica.

ficifolia...

saportana

Halymenites major minor

(1) 62,63 hastata, Paranymphaea........ 243, 250, pl. 52 haydenii, Platanus... Hell Creek formation, character of

collections from

flora of

fossil plant localities in

relations of

hirsutus, Carpolithus.

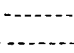

-

\section{I}

intermedia, Nelumbo.

interrupta, Thuja...

$\mathrm{J}$

johnstrupi, Nilssonia.

$\mathrm{K}$

Knowlton, F. H., quoted.

L

lakesii, Magnolia.

242, 243, 251, pl. 54

Lance formation, relations of (240

lanceolata, Laurus............... 53

lanceolatum, Cinnamomum.

lanceolatus, Podozamites.

Laramie formation, equivalent of

laramiense, Cinnamomum

laramiensis, Ginkgo.

Nelumbo.

$243,244-245$ 244-245

lata, Nilssonia

latipennis, Podozamites.

Lauraceae.

Laurus.

$242,243,250$, pl. 53

leei, Fraxinus

Lemna scutata

245, 248

248, 250

sp lutea, Nelumbo.... 250

\section{M}

Magnifolia

lakesii

nervosa

Magnoliaceae

major, Ginkgo pseudadiantoides... 245, 246

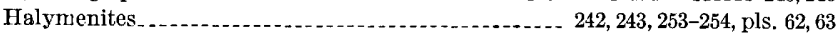
marcouanum, Liriodendron marginatum, Viburnum minor, Ginkgo

$$
\text { Halymenites }
$$

montana, Sassafras. . . . Moraceae.................. 248-249 morrisoni, Sapindus. Myrica torreyi

$\mathrm{N}$

Nelumbo dawsoni. intermedia laramiensis. . ................. lutea.. nucifera.

nervosa, Magnolia

Nilssonia.

gibbsii..

johnstrup

lata

yukonensis.

nordenskiöldi, Pistia

Sequoia

nucifera, Nelumbo

Nymphaeaceae. obtusa, Dombeyopsis......................

0

Page

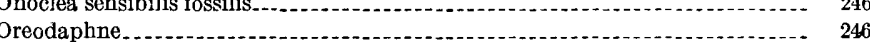

Ottelia americana

Palmocarpon.

sp........-...- 248

panduratus, Cissites.

Paranymphaea crassifolia_.......... hastata _.................................. 243, 250, pl. 52

penhallowi, Pterospermites

Phyllites cockerelli......... 242, 243, 253 sp .................. 242, 243, 245, 253, pls. 51, 60

Picea -

Pierre shale, age of relations of . . .

Pinus_._- 253

Pistia corrugata_................. 242, 243, 245, 248, pls. 49,56

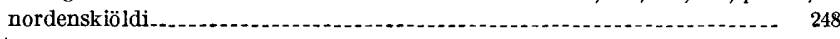
Platanaceae.

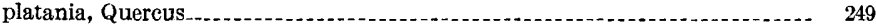

Platanus... . haydenii sp

Podocarpus stantoni

Podozamites lanceolatus... latipennis............... 245, 246 49

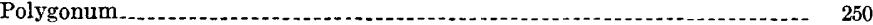

Polypodiaceae._._.

Populus_............. amblyrhyncha................... 240

cuneata__._.

praeimpressa, Cornus...-_... 55

preartocarpoides, Ficus....... 53

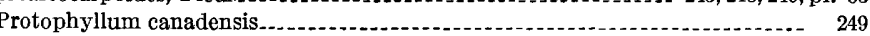

sp.......... 249

pseudadiantoides, Ginkgo...

Pteridophyta

Pterospermites nervosum.

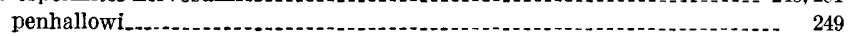

pungens, Artocarpus

Purpose and scope of the report

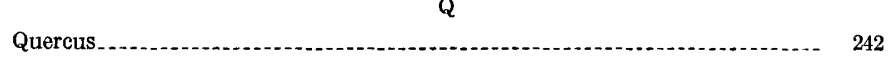

dawsoni $\ldots \ldots$

$\begin{array}{lll}\text { gracilis }-\ldots \ldots \ldots & 249\end{array}$

platania......... 249

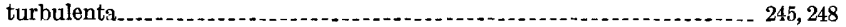

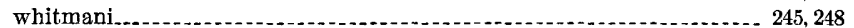

$\mathbf{R}$

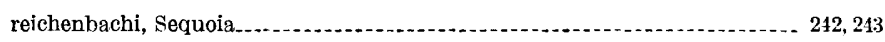

reniformis, Ginkgo

Rhamnus

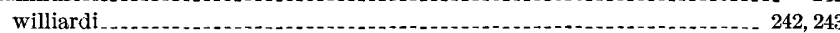

robusta, A nona_-

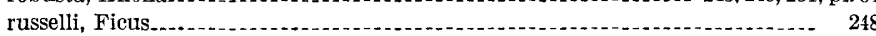

S

Salix

Sapindus ......... 251

affinis

cretaceus................................................... 243, 245, 251-252, pls. 55

grandifoliolus.

morrisoni...

Saportana, Grewiopsis .

Sassafras cretaceum

montana............ 243, 245, 250, pls. 52,55

scutata, Iemna.

sensibilis, Onoclea............................ 246

Sequoia..._. 246, 253

dakotensis....... $243,244,245,247$, pl. 48

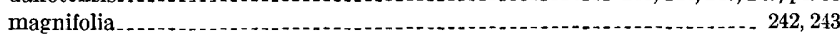

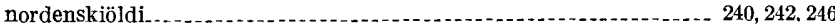

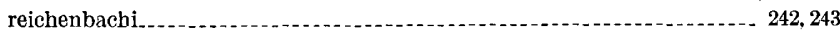

speciosissima, Ficus . . .

Spermatophyta....

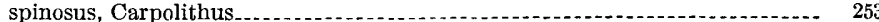


Page

stantoni, Castalia................ 245, 252 Podocarpus.

Vitis..

242,243

subfalcatum, Dryophyllum

$242,243,245,252$, pls. $56,57,58,59$ $242,243,245,248$, pls. $50,51,52,54$

Taeniopteris gibbsii

Taxodiaceae

Taxodium

Taxellum, Aspletium

Thuja__-..-. 247

colgatensis...... $242,243,245,247$, pl. 48

cretacea

interrupta.................... 247

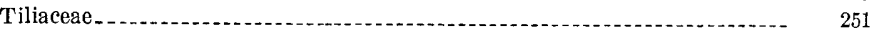

torrey i, Myrica............ 242, 243

Triceratops_................................................ 239, 241, 244, 245, 246, 248

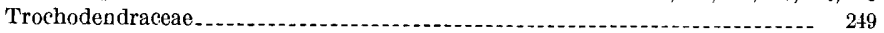

Trochodendroides. . .

sp.

turbulenta, Quercus .
$\mathrm{U}$

Page

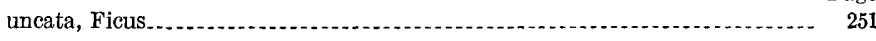

Viburnum marginatum................................ 243, 244, 245, 252, pl. 59

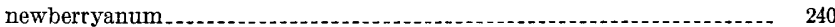

vulpinum .

sp

Vitaceae

Vitis

dakotana stantoni. - . . .

vulpinum _._.

vulpinum, Viburnum

Vitis

W

whitmani, Quercus._. 245,248

Williamsonia cretacea

williardi, Rhamnus. 

UNITED STATES DEPARTMENT OF THE INTERIOR

Harold L. Ickes, Secretary

GEOLOGICAL SURVEY

W. C. Mendenhall, Director

Professional Paper 189

\title{
SHORTER CONTRIBUTIONS TO \\ GENERAL GEOLOGY
}

\author{
1937
}

G. F. LOUGhlin, Chief Geologist

UNITED STATES

GOVERNMENT PRINTING OFFICE

WASHINGTON : 1939 



\section{CONTENTS}

[The letters in parentheses preceding the titles are those used to designate the individual papers]

(A) Species and genera of Tertiary Noetinae, by F. Stearns MacNeil (published in July 1938)

(B) Igneous geology and structure of the Mount Taylor volcanic field, New Mexico, by Charles B. Hunt (published in October 1938)

(C) Pliccene diatoms from the Kettleman Hills, California, by K. E. Lohman (published in July 1938)

(D) Oligocene Foraminifera from Choctaw Bluff, Alabama, by Joseph A. Cushman and Winnie McGlamery (published in August 1938) ...............

(E) The force required to move particles on a stream bed, by William W. Rubey (published in August 1938)

(F) The Venericardia planicosta group in the Gulf province, by Julia Gardner and Edgar Bowles (published in May 1939)..-

(G) Foraminifera, diatoms, and mollusks from test wells near Elizabeth City, North Carolina, by L. G. Henbest, K. E. Lohman, and W. C. Mansfield (published in _ - 1939)

(H) Pleistocene diatoms from Long Island, New York, by K. E. Lohman (published in April 1939) . . . . . . . . . .

(I) Fossil plants from the Colgate member of the Fox Hills sandstone and adjacent strata, by Roland W. Brown (puklished in September, 1939)

Page

\section{ILLUSTRATIONS}

Plate 1. Tertiary and Recent species of Scapularca, Sheldonella, Paranoetia, and Eontia

2. Miocene and Pliocene species of Eontia

3. Pliocene, Pleistocene, and Recent species of Eontia

4. Eocene species of Protonoetia, Noetiopsis, Arginopsis, Arginella, and Noetia

5. Miocene species of Noetia

6. Miocene, Pliocene, Pleistocene, and Recent species of Noetia

7. Map showing structure and reconnaissance areal geology of the volcanic rocks of the Mount Taylor field, N. Mex.

8. A, View of Mount Taylor; $B$ View looking northeast across erosion surface in Lobo Canyon- In pocket

9. Map showing drainage in Mount Taylor volcanic field

10. $A$, Porphyritic andesite flows near base of north flank of Mount Taylor; $B, \mathrm{~V}$-shaped valley cut in porphyritic andesite.

11. A, Cross section of basaltic neck exposed by erosion in Grant Ridges; $B$, Cliff face exposing basaltic breccia on rhyolitic tuff near the volcanic neck . .

12. $A$, Basaltic lava and einder cone on the sheet basalt capping Horace Mesa; $B$, View looking northeast from top of volcanic neck east of La Abra de los Cerros; $C$, View looking south from Cerro de los Cuates. ............

13. A, Cabezon Peak viewed from the bluffs above the village of Cabezon; $B$, Closer view of south side of Cabezon Peak showing fairly uniform vertical columns eapped with a layer of scoriaceous basalt

14. $A$, Volcanic neck east of La Abra de los Cerros; $B$, Xenolith of fossiliferous Cretaceous sandstone in basaltic breccia in neck in Gonzales Canyon.

15. $A, B$, Views of Evans Peak

16. $A$, View looking southwest toward Seboyeta Peak; $B$, Xenoliths of sedimentary rock in breccia along east side of Seboyeta Peak

17. $A$, Dike of basalt and basaltic breccia intruding Cretaceous shale; $B$, Banded basaltic breccia lying at outer contact of large breccia mass; $C, D$, Angular unconformity between Santa Fe formation and underlying Cretaceous rocks_...

18. $A$, Block diagram showing structural surface of part of Antonio Sedillo Grant at southwest corner of the area; $B$, Block diagram showing structural surface of most of north half of Basin and Range part of Mount Taylor volcanic field.

19. A, Flat-lying unbroken Santa Fe formation crossing a normal fault in Cretaceous shale; $B$, Basaltic lava in Santa Fe formation tilted and broken by small fault

20. Diatoms from the Etchegoin formation of South Dome, Kettleman Hills

21, 22. Diatoms from the Neverita zone and overlying tuffaceous sandstone and clay of the San Joaquin formation, Kettleman Hills.

23. Diatoms from the Tulare formation, Kettleman Hills

24. Valvulinidae, Miliolidae, Lagenidae, Polymorphinidae, and Nonionidae. 
26. Buliminidae and Rotaliidae

27. Rotaliidae

28. Amphisteginidae, Cassidulinidae, Anomalinidae, and Planorbulinidae

29. The occurrence of species of the Venericardia planicosta group in the Eocene of Alabama

30. The occurrence of species of the Venericardia planicosta group in the Eocene of the Atlantic and Gulf seaboard exclusive of Alabama

31. Areas of outcrop of marine beds of probable early Eocene age

32. Diagrammatic representation of diagnostic characters of the American species of the Venericardia planicosta group

33-46. Fossils of the Venericadria planicosta group

47. Views of the Colgate member of the Fox Hills sandstone and Hell Creek formation in southeastern Montana and southwestern North Dakota: $A$, Erosion remnant of Colgate sandstone 5 miles southwest of Glendive, Mont.; $B$, Outcrop of white Colgate sandstone overlain by somber-hued Hell Creek strata 4 miles southwest of Glendive, Mont.; C, Hell Creek formation north of the station of the Chicago, Milwaukee, St. Paul \& Pacific Railroad at Marmarth, N. Dak

48-63. Fossil plants from the Colgate member of the Fox Hills sandstone and adjacent strata

Figure 1. Diagrams showing relation of adult sculpture to nealogic sculpture

2. Diagram showing supposed relationships of North American species of Eontia

3. Index map of New Mexico showing location of Mount Taylor volcanic field

4. Diagrammatic view of part of Mount Taylor volcanic field

5. Sketch showing topographic relations in Lobo Canyon

6. Pedestal of alluvium about 50 feet high left standing in Chico Arroyo, 3 miles west of Cerro de los Cuates . - . -

7. Arroyo of Rio Puerco 2 miles north of Ojito ranch

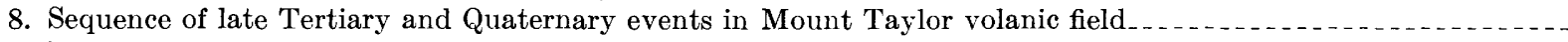

9. Hypothetical profile of Mount Taylor

10. Geologic sketch map of amphitheater and surrounding rim of Mount Taylor volcano

11. Sketch map showing intrusive basaltic breccia in Gonzales Canyon . .

12. Diagrammatic section through north side of Juan Tafoya Peak

13. Diagram of columnar jointing in intrusions 4 miles east-northeast of La Señora Peak

14. Sketch from photograph showing fault relations half a mile west of San Ysidro and 1,000 feet north of State Highway $44 \ldots \ldots$

15. Diagrammatic section illustrating faulting east of Mesa Lucero

16. Impact of moving water against particle on a stream bed

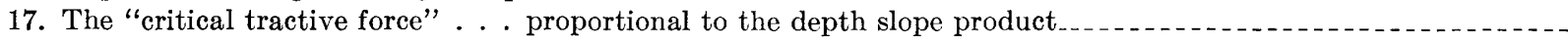

18. Typical vertical velocity curve of a stream

19. Mean velocities, depth-slope products, and movement of debris of grade $\mathrm{G}$

20. Mean velocities and depth-slope products at which debris of grades B, D, E, F, G, and $\mathrm{H}$ begins to move......

21. Roughness ratios, inverse measures of "bed" velocity and coefficient of resistance, and movement of debris of grade $\mathrm{G}_{-}$

22. "Bed" velocities, shearing stresses, and movement of debris of grades $\mathrm{E}, \mathrm{G}$, and $\mathrm{H}$

23. Portion of Hjulström's diagram of the fields of erosion, transportation, and sedimentation for well-sorted sediment.

24. Dependence of coefficient in impact equation upon the particle-laminar film ratio

25. Idealized velocity gradient very near a stream bed $\ldots$

26. Mechanical composition of samples collected in 1881 from the bed of the Mississippi River at Hannibal, Mo....-

27. Distribution of species of the Venericardia planicosta group in the Eocene of the Gulf Embayment and eastern Atlantic slope.

28. Index map of North Carolina, showing location of Elizabeth City area

29. Map of Elizabeth City and vicinity, showing location of test wells

30. Index map showing distribution of the Fox Hills sandstone.

\section{INSERTS}

Chart 1. Correlation of east coast and Gulf Eocene formations in the United States

2. Stratigraphic distribution of east coast and Gulf species of the Venericardia planicosta group.

3. Possible phylogenetic relationships in the east American Venericardia planicosta group. 
The use of the subjoined mailing label to return this report will be official business, and no postage stamps will be required

UNITED STATES DEPARTMENT OF THE INTERIOR GEOLOGICAL SURVEY

OFFICIAL BUSINESS

This label can be used only for returning official publica be changed.
PENALTY FOR PRIVATE USE TO AVOID PAYMENT OF POSTAGE, $\$ 300$

\section{GEOLOGICAL SURVEY,}


